NUPESTOR-1404 PNL-3381

\title{
Interaction of Uranium \\ Mill Tailings Leachate with Soils and Clay Liners
}

Laboratory Analysis/Progress Report

Orepared by G.W. Gee, A.C. Campbell, D.R. Sherwood,

R.G. Stricker, S.J. Phillips

Battelle-Pacific Northwest Laboratory

Prepared for

U.S. Nuclear Regulatory

Commission 


\section{NOTICE}

This report was orepared as an account of work sponsored by an agency of ine United States Government. Netther ine United States Government not any acency thereof. or any of their emoloyees. makes any warranty, expressed or implied. or assumes any legas liablity or resoonsibility for any inird party's use. or the resuts of such use. of any information. apoaratus product or process disclosec in this report. or represents that its use oy sucn inird party would rot iniringe privately owned rights.

Availacie from

gro saies Frogram

Sivision of Fechnical Information and Document Control

$\because$ S. ivuclear kegulatory Comission íssing:on, 2 . C. 20535

Printed cooy arics: $\$ 3.75$

and 


\section{Interaction of Uranium Mill Tailings Leachate with Soils and Clay Liners}

Laboratory Analysis/Progress Report

Manuscript Completed: May 1980

Date Published: June $\uparrow 980$

Prepared by G.W. Gee, A.C. Campbell, D.R. Sherwood,

R.G. Strickert, S.J. Phillips

Pacific Northwest Laboratory

Rieniand. WA 99352

\section{Prepared for}

Division of Safeguards, Fuel Cycle and Environmental Research

Office of Nuciear Regulatory Research

U.S. Nuclear Regulatory Commission

Wastington, D.C. 20555

NRC FIN No. B2292 
.

. 


\section{SUMMARY}

Laboratory tests were conducted to evaluate leachate from uranium mill tailings and its interaction with materials taken from the Morton Ranch Uranium Mill site in central Wyoming. Laboratory tests included:

1. Physical and chemical characterization of geologic materials from the Morton Ranch. The materials characterized were typical of those found in the area of the proposed tailings pits.

2. Physical and chemical characterization of acid leach tailings and tailings solution from the nearby Exxon Highland Mill.

3. Leaching tests with selected tailings materials and leach solutions.

4. Adsorption studies measuring the sorption characteristics of heavy netals and radionuclides on the Morton Ranch geologic materials under low and neutrai pH conditions.

5. Clay liner stability tests. These tests were designed to eyaluate the mechanisms of clay liner alteration under acid attack and to assess any long term changes in permeability of the clay liner materials.

Constitutents of the tested tailings solution that are possible contanjnants to ground water include arsenic, cadmium, chromium, copper, iron, manganese, selenium, zinc, sulfate, and several of the uranium daughter products including $\mathrm{Ra}-226$, Th-230, $\mathrm{Pb}-210$, and $\mathrm{Po}-210$.

Leaching studies indicated that excessive leaching was required before the tailings $\mathrm{pH}$ rose significantly. Leaching with alkaline ground water ( $\mathrm{pH} \mathrm{8)} \mathrm{required} \mathrm{30,} 42$ and 50 pore volumes to increase the erfluent $\mathrm{pH}$ above 4 for sands, tajlings, and slimes, respectively. The resulis indicate that these materials will remain a potential source of soluble contaminants for long periods of time.

When tailings solution was neutralized either by addition of $\mathrm{NaOH}$ or by contact with the Morton Ranch clay liner or overburden material, significant decreases in potential contamination were obtained for ali nonradioactive elements. Upon neutralization, most of the potential contaminants listed above dropped to or below the maximum permissible concentration (MPC). All soluble 
radioactive constituents dropped significantiy below MPC vaiues. Upon contact of the tailings solution with the geologic materials tested, the radionuclides showed moderate to strong sorption even at low $\mathrm{pH}$.

Tests on clay Iiner material from the Morton Ranch indicated the following:

1. Environmental Protection Agency liner criteria are met by the Morton Ranch clay liner - indicating that the test material should be a suitable barrier to contaminant migration.

2. The clay is not dispersive, hence piping-type erosion will not occur.

3. Mineralogy of the clay material changes only slightly even after extended contact with the tailings solution. For the pH and dissolved solids concentration of the tailings solution, acid dissolution of crystalline clay minerais appears to be countered by precipitation reactions and secondary mineral formation.

4. Permeability of clay liner materiai always decreased with time. The decreases in permeability were most likely due to pore plugging by secondary clay minerais and precipitates.

5. Packing of the clay liner affected permeability more than any other single factor. Packing of clay to optimum density should assure that minimum permeability is obtained in clay-lined pits or ponds. 


\section{ACKNOWLEDGMENTS}

This study was sponsored and supported by the Waste Management Branch, Division of Safeguards, Fuel Cycle, and Environmental Research of the United States Nuclear Regulatory Comission. The authors gratefully acknowledge the interest, helpful suggestions and encouragement provided by Laura Santos throughout the study as project administrator for NRC and special credit and thanks are expressed to C. E. Wolff, T. O. Hiscox, C. H. Likens, and T. G. Workman, of United Nuclear Corporation of the Morton Ranch Operation for supplying test materials and providing unhesitating cooperation throughout the study. We also express thanks to O. M. Range of Exxon's Highland Mill, who supplied us with the uranium mill tailings, tailings solution, and mill process water used in this study. Finally, we express appreciation to our colleagues at Pacific Northwest Laboratory, L. L. Ames, R. J. Serne, O. Rai, J. F. Relyea, and R. A. Walter, for their suggestions and advice during the study. 


\section{CONTENTS}

SUMMARY

ACXNOWLEDGMENTS

FIGURES

TABLES

INTRODUCTION

1.0 CHARACTERIZATION OF MATERIALS . . . . . . . . . . 2

CHARACTERIZATION OF MORTON RANCH GEOLOGIC MATERIAL . . . . 2

CHARACTERIZATION OF TAILINGS AND TAILINGS SOLUTION . . . . 6

2.0 LEACHING STIJDIES . . . . . . . . . . . . . . . . 11

3.0 ATTENUATION STLDIES . . . . . . . . . . . . . . . . . 14

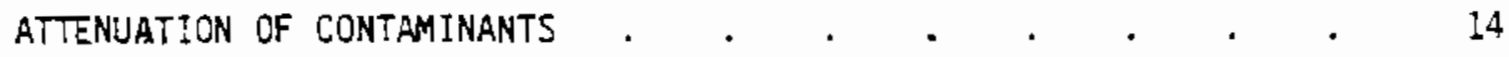

TESTS RESULTS . . . . . . . . . . . . . . . . . . . 16

4.0 CLAY LINER TESTS . . . . . . . . . . . . . . . . 20

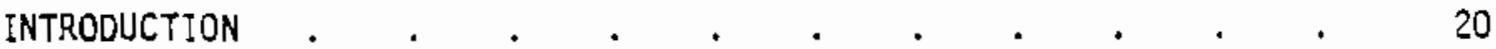

MATERIALS AND METHODS . . . . . . . . . . . . . 21

RESULTS AND DISCUSSION . . . . . . . . . . . . . . . . 23

Liner Criteria. . . . . . . . . . . 23

Dispersion Test Results . . . . . . . . . . . 23

Mineralogical Tests. . . . . . . . . . . . 24

$X$-ray Diffraction $. \quad . \quad . \quad . \quad . \quad . \quad . \quad . \quad . \quad 26$

Scanning Electron Microscopy . . . . . . . . . 36

Permeability Tests . . . . . . . . . . . . . 33 


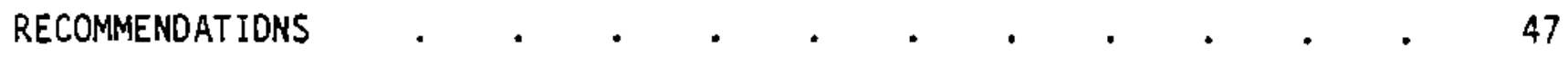

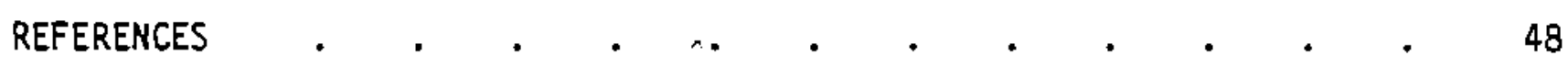

APPENDIX A - ICP ANALYSIS OF THE URANIUM MILL TAILINGS SOLUTIONS • • A-I

APPENDIX B - METHOD FOR DETERMINATION OF GAMMA EMITTING RADIONUCLIDES

IN URANIUM MILL TAILINGS AND TAILINGS SOLUTION . . . B-1 


\section{FIGURES}

1.1 Location of Morton Ranch Miil Sites in Central Wyoming . . . 3

1.2 Generalized Map of the Powder River Basin in Relation to Structural Features . . . . . . . . . . . 4

1.3 Particle Size Surmation Percentage Curve for Morton Ranch Test Materials

2.1 Changes in Effluent pH Due to Leaching . . . . . . . . 14

4.11704 Pit at Morton Ranch. . . . . . . . . 22

4.2 Solution Comosition of Tailings Solution and Leachate from Tailings Related to Dispersion Potential Criteria Established by Sherard et al. 1976.

4.3 X-ray Diffraction of the $>10$; 10 Fraction of Morton Ranch

Clay Liner Material. . . . . . . . . . . . . . 27

4.4 X-ray Diffraction of the $>10 \mu \mathrm{m}$ Fraction of Bentonite Clay Liner Material.

4.5 X-ray Diffraction of the $>10$ un Fraction of Saline Seal Clay Liner Material.

4.6 SEM Photomicrograph of Composite Clay Liner . . . . . . 30

4.7 SEM Photomicrograph of Bentonite . . . . . . . . . 31

4.8 SEM Photomicrograph of Bentonite Saline Seal. . . . . 32

4.9 Pressurized Flow System for Determining Constant Head Permeability . . . . . . . . . . 35

4.10 Pressurized Permeameter Setup for Measuring Permeability of Clay Liner Materials

4.II Permeability of Morton Ranch Clay Liner Material as a Function of Time . . . . . . . . . . . . . 37

4.12 Permeability of Morton Ranch Dverburden as a

4.13 Effluent pH as a Function of Eluted Pore Volumes for Morton Ranch Clay Liner 
4.14 Effluent $\mathrm{pH}$ as a Function of Pore Volumes Eluted from

4.15 Relative Concentration of Sulfate in Effluent from Morton Ranch Clay Liner as a Function of Effluent Pore Volumes . . 42

4.16 Relative Concentration of $\mathrm{Al}$ and $\mathrm{Fe}$ in Effiuent from Morton Ranch Clay Liner as a Function of Effiuent Pore Volumes . . 43

4.17 Relative Concentration of Silicon in Effluent from Morton Ranch Clay Liner as a Function of Effluent Pore Voiumes . . 45

B.1 Detector Efficiency Curve for Intrinsic Germanium Diode . . B-6

B.2 Energy Spectrum for Th-227 Double Peak for Intrinsic Germanium Diode 


\section{TABLES}

1.1 Characterization of Morton Ranch Clay Liner, Overburden,

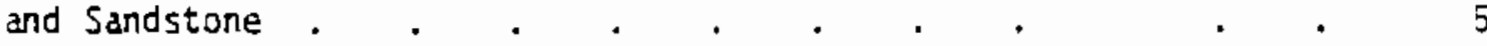

1.2 Characterization of Highland Mill (Acid Leach) Tajlings . . 7

1.3 Characterization of Tailings Solutions and Mill Process Water . 9

1.4 Radionuclide Concentrations in the Highland Mill Tailings and Tailings Solution . . . . . . . . 10

2.1 Experimental Parameters for Leaching Studies. . . . . 12

2.2 Chemical Analysis of Leachate Solutions. . . . . . . 13

3.1 Batch Kd Values (mg/l) Using Untreated and Neutralized Uranium Mill Tailings Solution for 10-Day Contact Periods with Morton Ranch Materials . . . . . . . . . . . 17

3.2 Data Used in Calculating Batch Kd Values . . . . . . 18

3.3 Effective Kd Vaiues Due to Neutralization . . . . . . 19

4.1 EPA Soil Liner Criteria. . . . . . . . . . 20

4.2 EPA Criteria and Morton Ranch Clay Liner Characteristics . . 23

4.3 Total Elemental Analysis of Morton Ranch Clay Liner, Bentonite, and Saline Seal Liner Before and After Treatment with

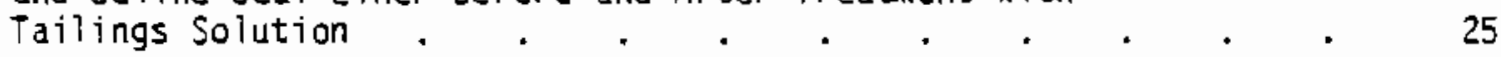

4.4 Identified Clay Minerals and Relative Abundance, Determined by $X$-ray Diffraction Analysis on Liner Samples Material Treated as Specified in Table 4.3. . . . . . . . . . . . 25

4.5 Physical Data for Test Materials . . . . . . . 33

4.5 Macroconstituents of Tajlings Solution . . . . . . . 34

A.1 Detection Limits for Water Reportad by Several Manufacturers of
Inductively Coupled Argon Plasma Emission Spectrometer. . A-1

A.2 Standard Composition and Detection Limits for ICP Analysis . . A-3

A.3 ICP Data for Two Standards Showing Matrix Interferences . . A-4 
A.4 Effect of IM Acids on Analytical Signals of Elements at the $250 \mu \mathrm{g} / \mathrm{T}_{\text {Level }}$. . . . . . . . . . A-5

A.5 Matrix Interference from $1000 \mathrm{mg} / 1$ Concentrations of $\mathrm{Al}$, $\mathrm{Ca}, \mathrm{Fe}$ and $\mathrm{Mg}$ with Other Elements . . . . . . . A-6

A.6 Analysis of UMT Synthetic Solution . . . . . . . . A-7

A.7 ICP Analysis: Permeability Cell P1 - Clay Liner and Synthetic Tailings Solution . . . . . . . . A-10

A.8 ICP Analysis: Permeability Cell P5 - Clay Liner and Tailings Solution . . . . . . . . . . . A-11

A.9 ICP Analysis: Permeability Cell P8 - Overburden and Tailings Solution .. . . . . . . . . . A-12

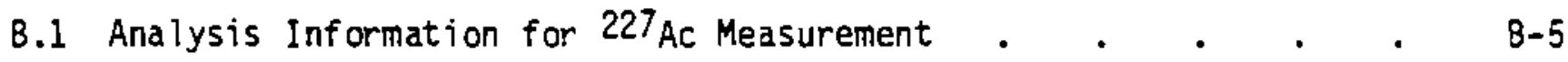

B.2 Radionuclide Concentrations from Energy Spectrum Analysis . . 8-5 


\section{INTRODUCTION}

Pit disposal of uranium mill tailings has been proposed for the Morton Ranch uranium mill in central wyoming (USNRC 1979a). The placement of taitings near the ground water has raised concerns about potential contamination of ground water by leachate from the acid tailings. This study evaluates leachate-soil interactions that will take place at the Morton Ranch for certain disposal alternatives. Laboratory tests were conducted to evaluate the following:

1) physical and chemical characteristics of geologic materials from the Morton Ranch,

2) physical and chemical characteristics of acid leach tailings and tajlings solution,

3) leaching tests with selected tajlings materials and leach solutions to evaluate the leachability of contaminants with time under specific disposal alternatives,

4) adsorption studies measuring the sorption characteristics of heavy metals and radionuclides on the geologic materials at Morton Ranch,

5) clay liner stability tests to evaluate effects of acid leachate on clay mineralogy and clay permeability. 


\subsection{CHARACTERIZATION OF MATERIALS}

CHARACTERIZATION OF MORTON RANCH GEOLOGIC MATERIAL

The Morton Ranch Uranium Mine and Mill Site is located in central Wyoming in Converse County (Figure 1.1). The geology of the area is discussed in detail in the UNC Environmental Report (UNC 1976). Briefly, the site iies in the southernmost part of the Powder River Basin. This basin is a large structural depression bounded on all sides by areas of uplift (See Figure 1.2). The area to the east rises to the Black Hills and the area to the west rises into the eastern slopes of the Big Horn and Wind River ranges of the Rocky Mountains. Since pre-Cambrian times, the history of the Powder River Basin has consisted largely of periods of subsidence and sedimentation. Accumulation of sedimentary rocks has occurred to depths of $4570 \mathrm{~m}(15,000 \mathrm{ft})$. The underlying sediments of the basin are primarily carbonates, sands and shales deposited in a marine environment. The uppermost sediments are fresh water fluvial (river transported) deposits of the Fort Union and Wasatch Formations. The Was atch Formation is the uppermost bedrock unit exposed throughout the mill site area. In this area, all but the bottom $+100 \mathrm{~m}(+330 \mathrm{ft})$ has been stripped away by stream erosion. The Wasatch Formation is comprised of fluviai sediments of interbedded silty claystones and sandy siltstones that contain thick lenses of coarse, arkosic (granular) sandstone. A few thin limestone and coal seams (less than $1 \mathrm{~m}$ thick) occur locally within the formation. The Fort Union Formation underlies the Wasatch formation and typicaily consists of poorly consolidated continental deposits about $100 \mathrm{~m}$ thick. At the mill site area, the formation consists of fluviai, interbedded silty claystones, sandy siltstones, relatively clean sandstones and granular sands. The sandstones of the upper Fort Union Formation are the host rocks for the uranium deposits.

It is the wasatch Formation materials and surface alluvium that will be mined and mixed to comprise the overburden and the clay liner materials used in the pit and pond disposal sites at the Morton Ranch Mill. The clay liner material will be selected primarily for its silt and clay content. The 


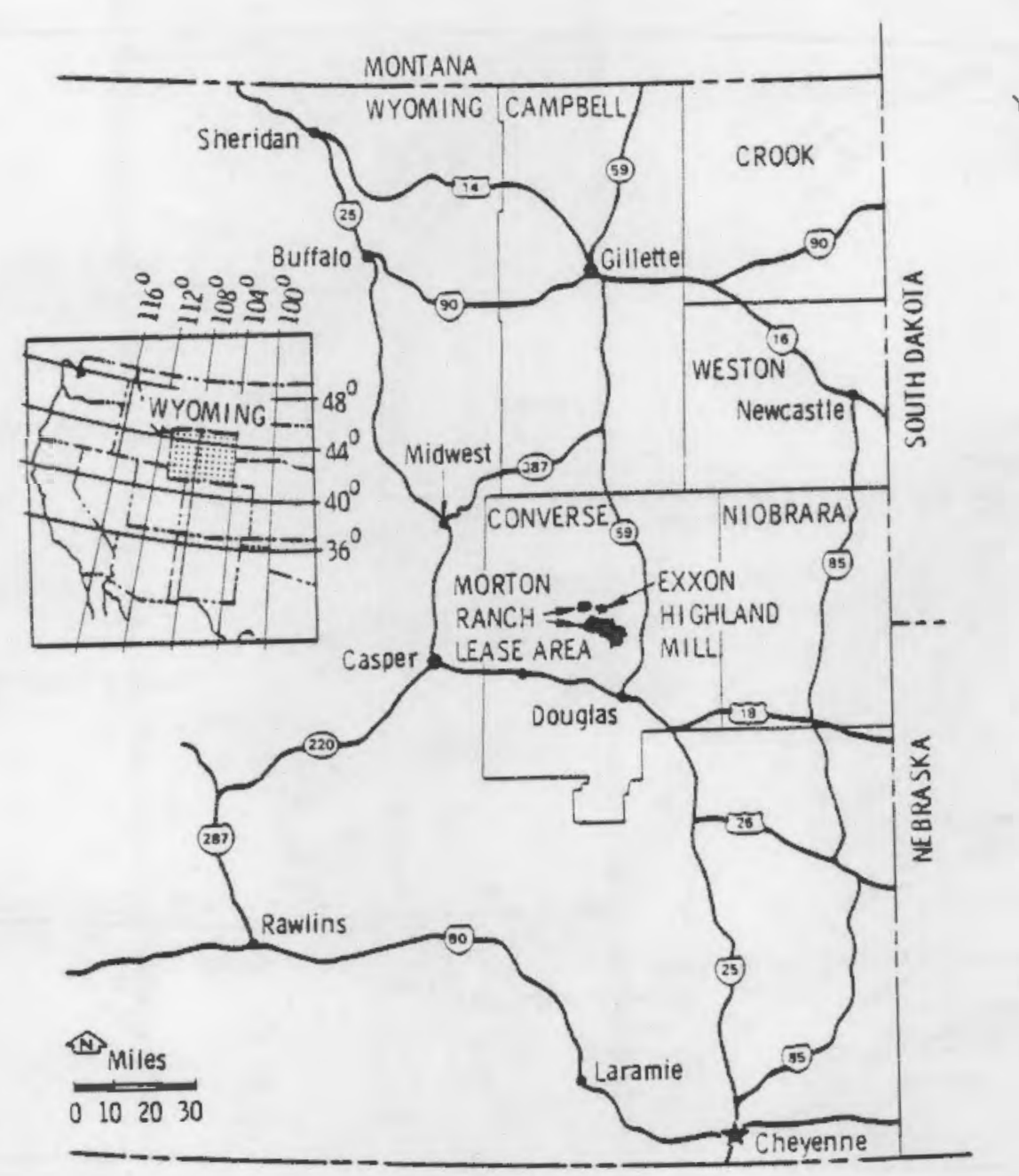

FIGURE 1.1 Location of Morton Ranch Mill Site in Central Wyoming

claystones and siltstones of the Wasatch Formation are the likely choices for the liner material. The overburden used as backfill material at the pits and for fill at the evaporation pond will be a mixture of clay, silts and sands from both the Wasatch Formation and the overlying alluvium. The exact mixture will be site specific and will depend on the proportions of sandstones, shales and claystones present in a particular excavation and the resulting mix of these materials in the excavation and stockpiling process. There is no way at present to determine, a priori, what the mixture, even at a particular pit, will be since mixing and stockpiling procedures tend to produce a random mix of materials. 


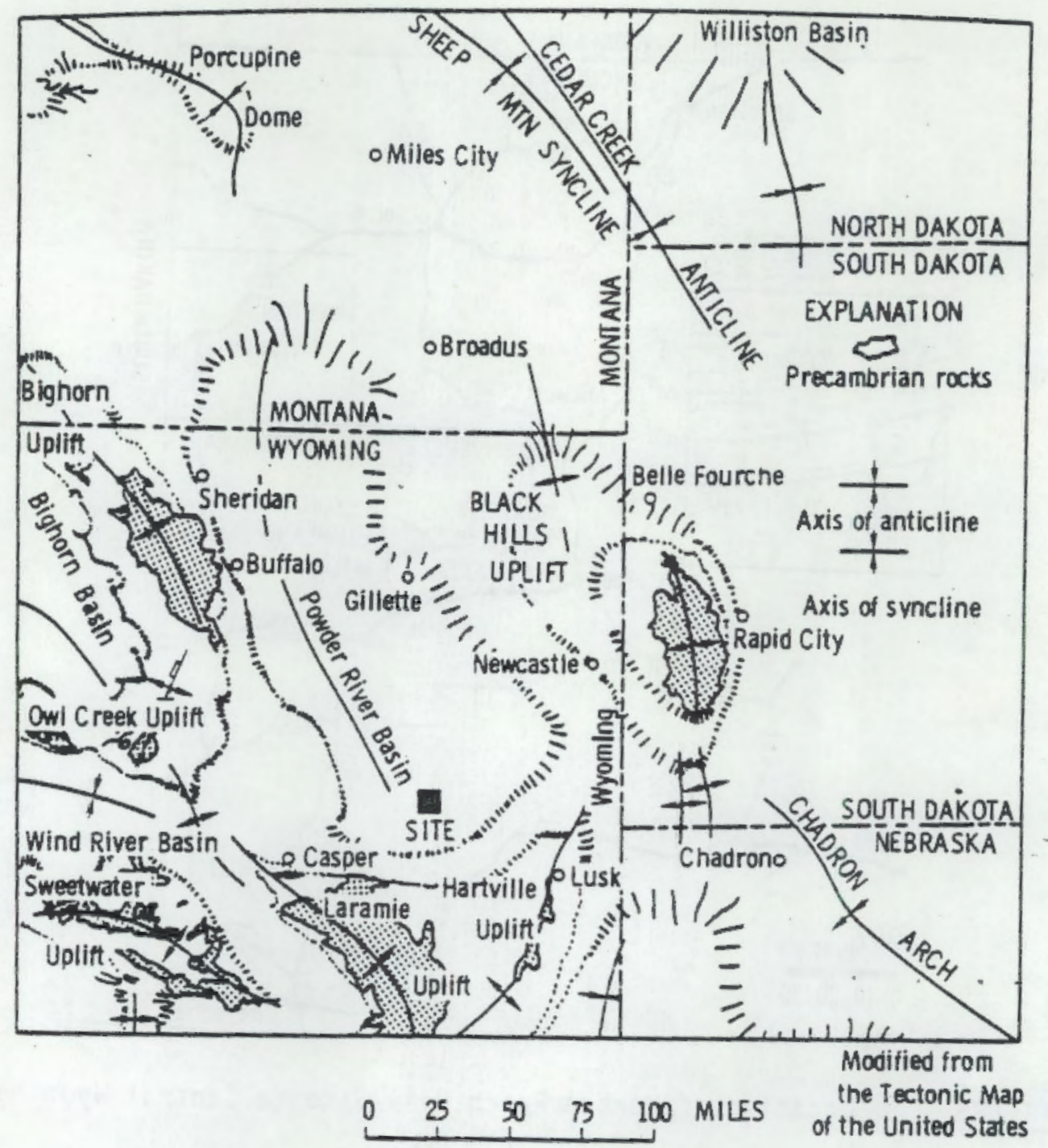

FIGURE 1.2. Generalized Map of the Powder River Basin in Relation to Structural Features (after USNRC 1979a)

In attempting to analyze the physical, chemical and hydrologic character of materials at the Morton Ranch site and proposed disposal area, we had to use personal judgment to select materials that are typical or characteristic of the site. Cross-section data with attendent geologic strata identified were supplied by United Nuclear Corporation personnel. In addition, representative samples of clay liner, overburden, and sandstone materiais were taken from the 
1704 pit area at the Morton Ranch. In consultation with Morton Ranch personnel, it was felt that these materials reflected the typical characterisics of the geologic materials that would be found at the tailings disposal sites. The mill tailings material was obtained from the Exxon Highland Mill. It was shipped to Battelle Pacific Northwest Laboratory as a $1: 2$ slurry of tailings and tailings solution.

Morton Ranch clay liner material, overburden, and sandstone were characterized using standard procedures (B1ack 1965). All the materials were taken from exposed side walls of the partially-mined 1704 pit at the Morton Ranch site. The clay liner material analyzed was a composite of sandstone, siltstone, mudstone, and shale. Results of physical and chemical analysis are given in Table 1.1. Figure 1.3 shows the particle size analysis for the geologic materials tested.

TABLE 1.1. Characterization of Morton Ranch Clay Liner, Overburden, and Sandstone

Parameter

$\mathrm{pH}$ of Saturation Paste (Distilled Water)

Particle Density $\left(\mathrm{g} / \mathrm{cm}^{3}\right)$

$\mathrm{CaCO}_{3}$ Equivalent ( $(\%)$

Organic Matter Content (\%)

Cation Exchange Capacity (meg/100g)

EC of Saturation Paste (mnhos/cm)

SAR (meq/1)

Particle Size Distribution

Sand $(50-2000 \mu \mathrm{m})$

silt $(2-50 \mu \mathrm{m})$

Clay (<2 um)

Surface Area $\left(\mathrm{m}^{2} / \mathrm{g}\right)$

ND $=$ Not determined
Clay Liner Overburden Sandstone

$$
8.2
$$

8.3

7.5

2.72

2.68

2.67

0.04

0.02

0.009

1.44

0.18

ND

31.6

10.3

9.47

0.70

0.34

ND

0.58

0.76

ND
12.0

54.0

34.0

230
75.5

15.0

9.5

78
86.3

7.2

6.5

11 


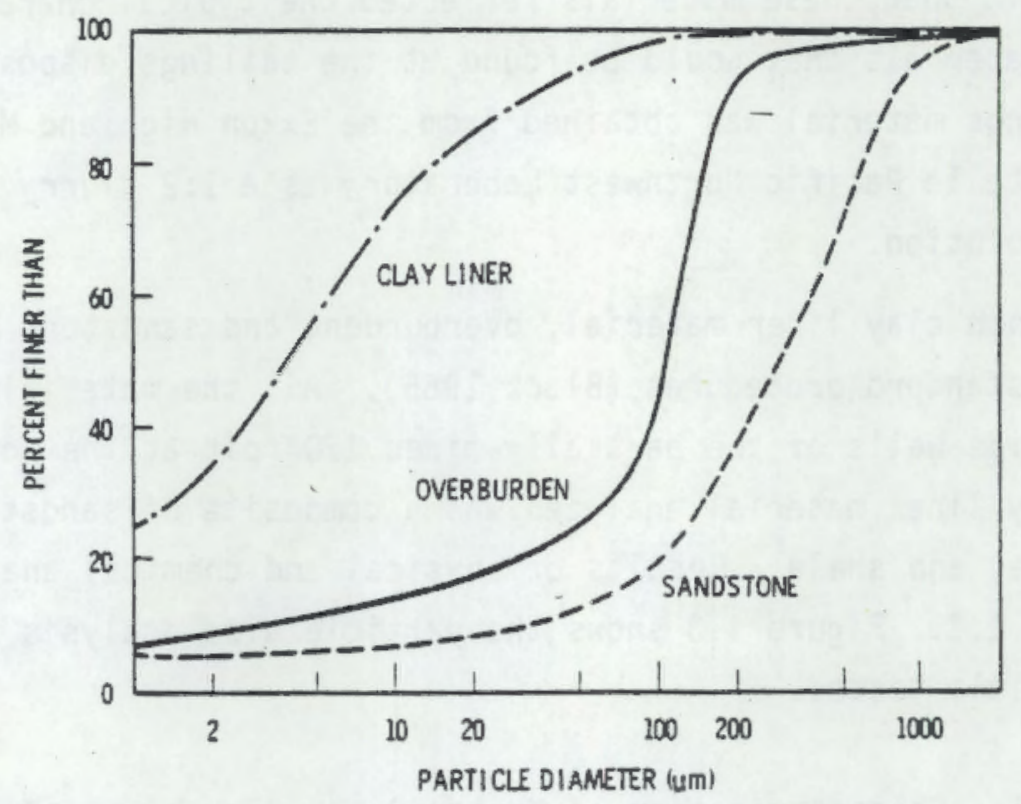

FIGURE 1.3. Particle Size Sumation Percentage Curve for Morton Ranch Test Materials

\section{CHARACTERIZATION OF TAILINGS AND TAILINGS SOLUTION}

A tailings slurry sample from Exxon's Highland Mill was analyzed for its physical, chemical, and radiological properties. The acid leach processing of ore at the Highland Mill is similar to that proposed for Morton Ranch, so the tailings should be characteristic of the type that will be produced at theMorton Ranch Mill. A sample of Exxon's mill process water was also analyzed.

The siurry was separated into its tailings and solution portions for analysis. A portion of the slurry was further divided into its $s$ and ( $>74 \mu \mathrm{m}$ to $2000 \mu \mathrm{m})$ and slime $(<74 \mu \mathrm{m})$ fractions. Physical and chemical properties of the tailings are listed in Table 1.2. The separated tailings had a pH of 2.3, and is classified as a sandy loam based on particle-size distribution. The dispersant, sodium-hexametaphosphate, was used to resuspend fines that acted as sands in the particle-size distribution tests. Flocculant, added in the mill process, apparently increased the ratio of sand to slime in the tests in which dispersant was not used (Table 1.2). 
TABLE 1.2. Characterization of Highland Mill (Acid Leach) Tailings

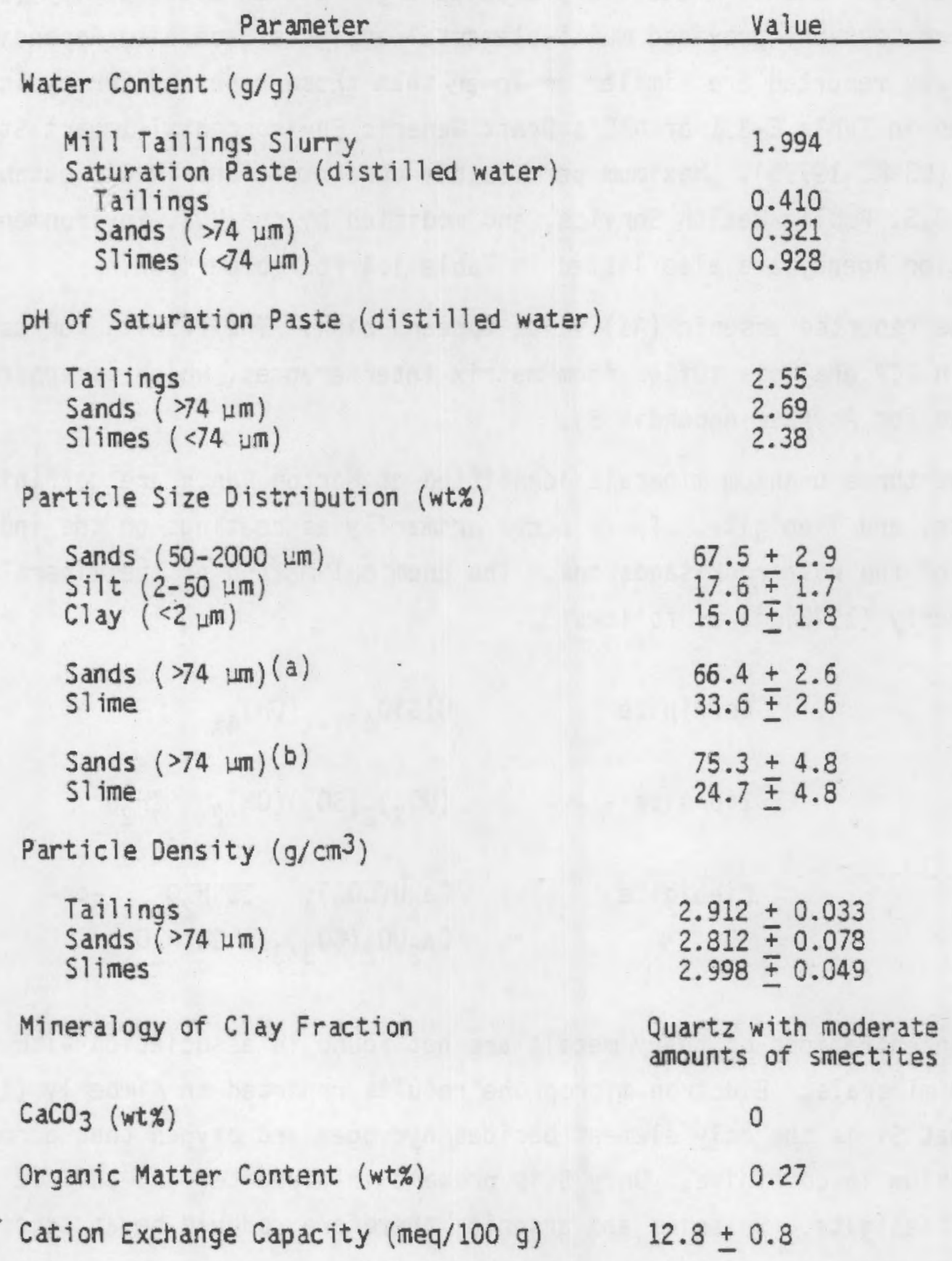
(a) With dispersant
(b) Without dispersant 
Characterization of the tailings solution and mill process water is shown in Table 1.3. Use of inductively-coupled argon plasma spectroscopy (ICP) and ion chromatography provided multi-elemental analysis (see also Appendix A). The values reported are similar or lower than those reported for typical mills as given in Table E-3.1 of NRC's Draft Generic Environmental Impact Statement (GEIS) (USNRC 1979b). Maximum permissible concentrations (MPC), established by the U.S. Public Health Service, and modified by the U.S. Environmental Protection Agency are also listed in Table 1.4 for comparison.

The reported arsenic (As) value appears high. The results for some elements in ICP analysis suffer from matrix interferences, which is apparently the case for As (see Appendix B).

The three uranium minerals identified at Morton Ranch are coffinite, zippeite, and liebigite. These occur primarily as coatings on the individual grains of the host rock sandstone. The chemical makeup of the minerals, given by Kimberly (1978) is as follows:

$$
\begin{array}{ll}
\text { Coffinite } & U\left(\mathrm{SiO}_{4}\right)_{1-x}(\mathrm{OH})_{4 x} \\
\text { Zippeite } & \left(\mathrm{UO}_{2}\right)_{2}\left(\mathrm{SO}_{4}\right)(\mathrm{OH})_{2} \quad 2_{2} \mathrm{O} \\
\text { Liebigite } & \mathrm{Ca}_{2} \mathrm{U}\left(\mathrm{CO}_{3}\right)_{4} \quad \mathrm{COH}_{2} \mathrm{O} \quad \text {-or- } \\
& \mathrm{Ca}_{2} \mathrm{UO}_{2}\left(\mathrm{CO}_{3}\right)_{3} \quad 10 \mathrm{H}_{2} \mathrm{O}
\end{array}
$$

High concentrations of heavy metals are not found in association with these uranium minerals. Electron microprobe results reported in Kimberly (1978) show that $\mathrm{Si}$ is the only element besides hydrogen and oxygen that accompanies the uranium in coffinite. Only $\mathrm{S}$ is present in zippeite; and only $\mathrm{Ca}$ is present in liebigite. Selenium and arsenic, therefore, should be at concentrations lower than are found in most other uranium ore types.

Based on the radiological information given in Table $1.4,238 U$ is the only isotope in the tailings solution with a concentration less than NRC's maximum permissible concentration for soluble radioactive materials that can 
TABLE 1.3. Characterization of Tailings Solution and Mill Process Water, $\mathrm{mg} / 1$ Unless Otherwise Noted

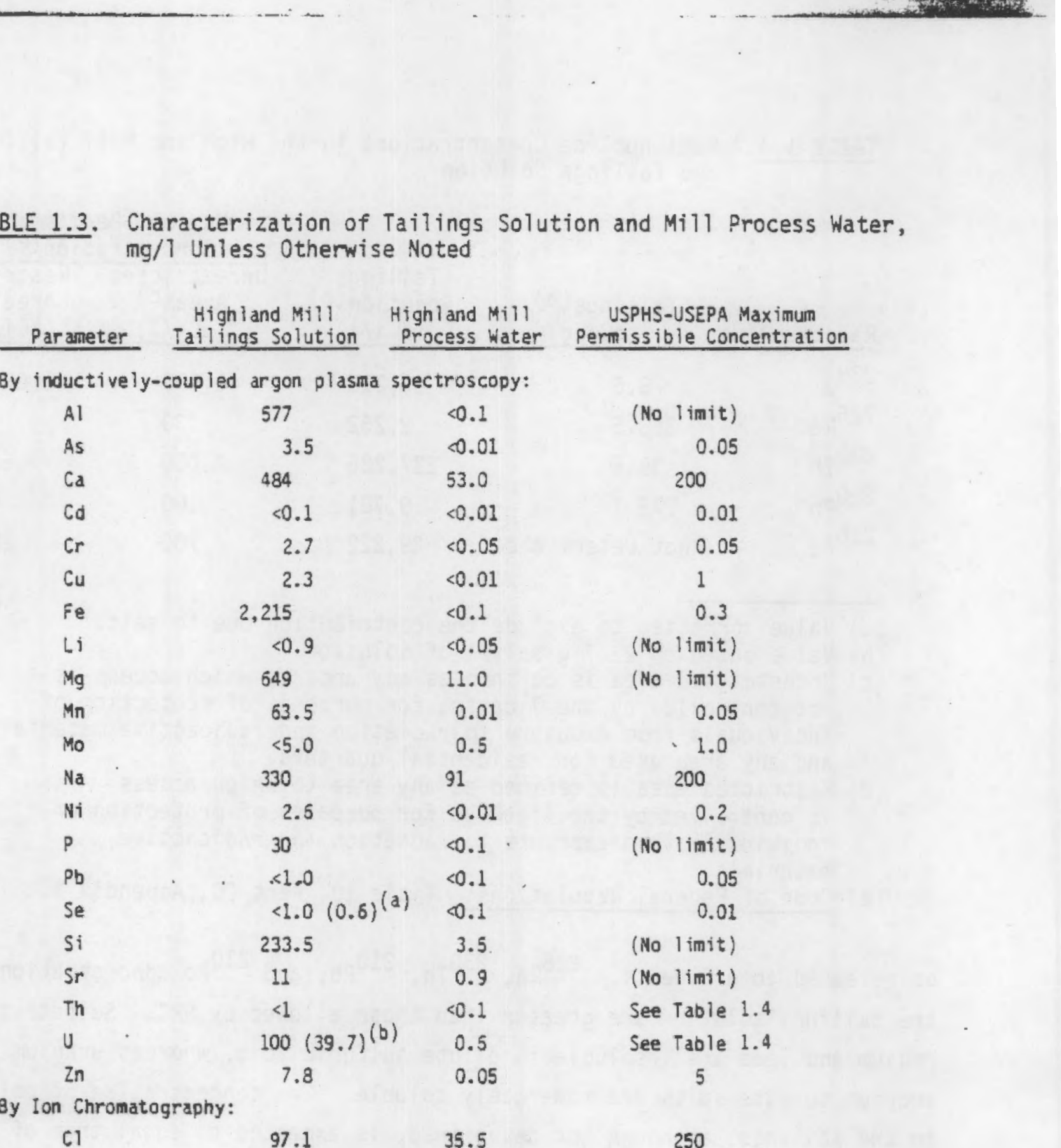

By inductively-coupled argon plasma spectroscopy:

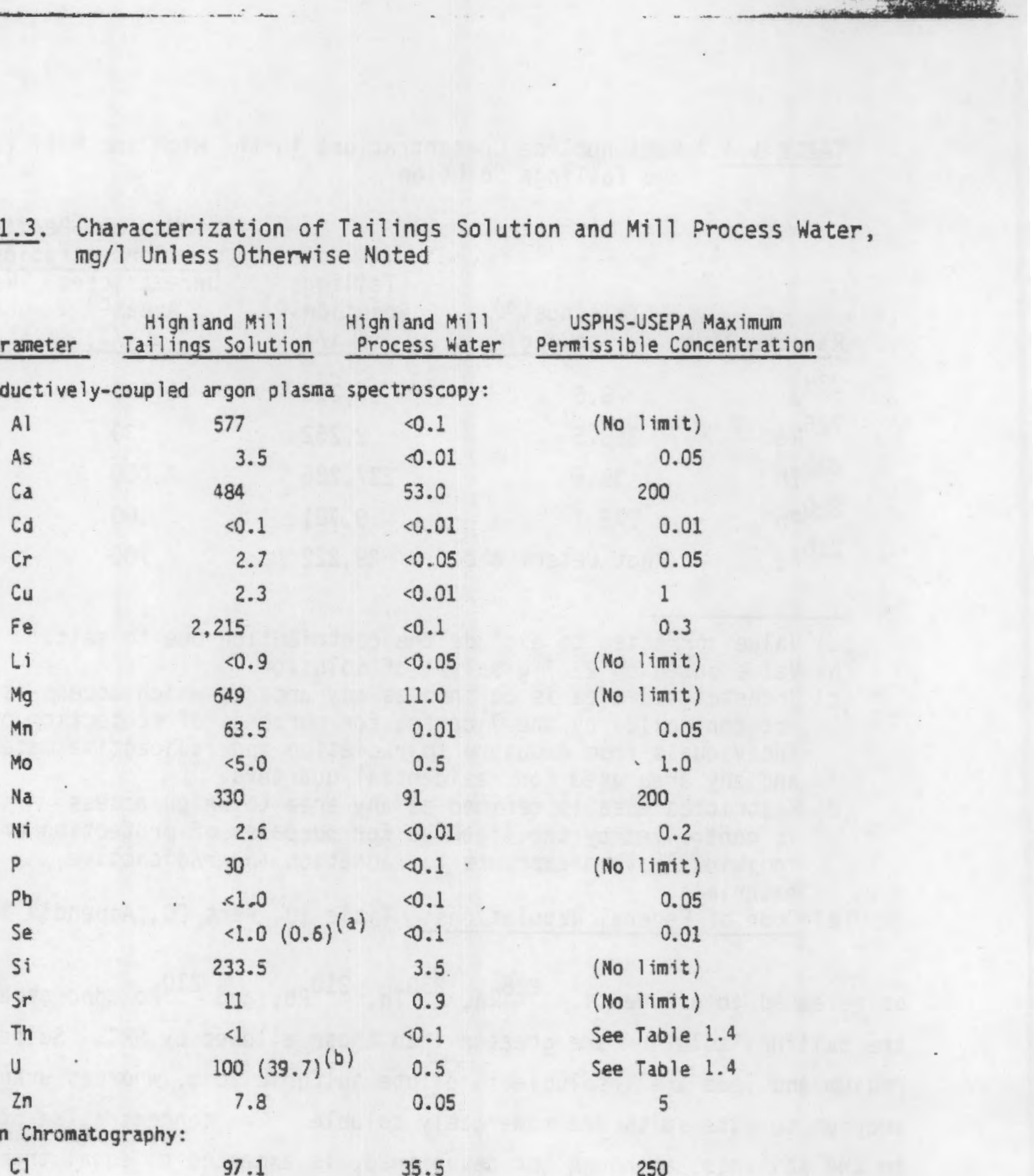

8y Ion Chromatography:

c1

97.1

3.6

3.6

10

$\mathrm{SO}_{4}$

12,850

181.4

250

EC (mmhos/cm)

18.2

0.82

Hardness (as mg $\mathrm{CaCO}_{3} / 1$ )

10,231

73.5

pH (Units)

1.8

8.2

6-9

(a) Gaseous hydride method

(b) Radiochemical analys is 
TABLE 1.4. Radionuclide Concentrations in the Highland Mill Tailings and Tailings Solution

\begin{tabular}{|c|c|c|c|c|}
\hline Radionuclide & $\begin{array}{c}\text { Tailings(a) } \\
(p C i / g) \\
\end{array}$ & $\begin{array}{c}\text { Tailings } \\
\text { Solution(b) } \\
(\mathrm{pC}(\mathrm{C} / \mathrm{T}) \\
\end{array}$ & $\begin{array}{c}\text { Unrestrjeted } \\
\text { Area }(\mathrm{c}) \\
(\mathrm{pC}(\mathrm{l}) \\
\end{array}$ & $\begin{array}{l}\text { Restrjcted } \\
\text { Area }(d) \\
(\mathrm{pC} i / 1) \\
\end{array}$ \\
\hline $238 U$ & 8.6 & 13,216 & 40,000 & $1,000,000$ \\
\hline & 368.5 & 2,252 & 30 & 400 \\
\hline & 39.6 & 227,286 & 2,000 & 50,000 \\
\hline${ }^{210} \mathrm{~Pb}$ & 275.7 & 9,701 & 100 & 4,000 \\
\hline Dpo & Not Determined & 28,222 & 700 & 20,000 \\
\hline
\end{tabular}

(a) Value corrected to exclude the contribution due to sait.

(b) Value based on $22.7 \mathrm{~g} \mathrm{salt/1}$ of solution.

(c) Unrestricted area is defined as any area to which access is not controlled by the licensee for purposes of protection of individuals from exposure to radiation and radioactive materials, and any area used for residential quarters.

(d) Restricted area is defined as any area to which access is controlled by the licensee for purposes of protection of individuals from exposure to radiation and radioactive materials.

(e) Code of Federal Reguiations. Title 10, Part 20, Appendix B.

be released in effluents. ${ }^{226} \mathrm{Ra},{ }^{230} \mathrm{Th},{ }^{210} \mathrm{pb}$, and ${ }^{210} \mathrm{po}_{\mathrm{o}}$ concentrations in the tailings solution are greater than those allowed by NRC. Sulfate salts of radium and lead are insoluble in dilute sulfuric acid, whereas uranium and thorium sulfate saits are moderately soluble. The concentration of poionium in the tailings, although not determined, is expected to equal that of ${ }^{210} \mathrm{pb}$. 


\subsection{LEACHING STUDIES}

Leaching studies were designed to simulate the following aiternatives for tailings disposal:

1) leaching of dewatered tailings placed below the ground-water table with ground water

2) leaching of slimes with ground water

3) leaching of sands with ground water

4) leaching of tailings slurry with diluted tailings solutions

5) leaching of ore grade material with ground water.

Mill process water as received from Exxon was used as the ground water. The diluted tailings solution was a 1:4 ratio of filtered tailings solution and distilled water. Samples were leached in a once-through flow system using a mechanical vacuum extractor (Concept Engineering, Inc., Lincoln, Nebraska) at an average rate of $39.8 \mathrm{~cm} /$ day with an average residence time of $1.6 \mathrm{hrs}$ per pore volume of effluent. The experimental parameters are listed in Table 2.1. Effluent $\mathrm{pH}$ was monitored and is plotted with its respective pore volume in Figure 2.1. A leach cycle was completed after every $55 \mathrm{ml}$ of solution added.

Effluent pH values were initially similar for segregated (slime versus sand) and nonsegregated tailings. Continued leaching by ground water (Highland Mill process water) resulted in slowly increasing pH values for the tailings, slimes, and sands, with oH values increasing most rapidly for the sand samples. There was very little change in effluent pH for the tailings slurry leached with diluted tailings solution. Soils with higher proportions of organic matter and clay tend to resist changes in pH because of greater surface areas and higher cation exchange capacities, which can sequester the hydrogen ion. The effluent $\mathrm{pH}$ values reflect these differences in buffering capacity of various components of the tailings. Data from the leaching studies indicate that the equivalent of 42.5 pore volumes of ground water at $\mathrm{pH} 8.1$, would be required to neutralize the tailings to a $\mathrm{pH}$ of 4 . 
TABLE 2.1. Experimental Parameters for Leaching Studies

\begin{tabular}{|c|c|c|c|c|c|}
\hline Parameter & Tailings & Slimes & Sands & Ore & $\begin{array}{l}\text { Tailings } \\
\text { Slurry } \\
\end{array}$ \\
\hline Leaching Solution &.$---M i 1$ & 11 Process & Water- & -...- & $\begin{array}{l}\text { Dilute } \\
\text { Tailings } \\
\text { Solution }\end{array}$ \\
\hline Influent $\mathrm{pH}$ & $\cdots$ & $-\cdots-10$ & -2 & $\cdots$ & 2.50 \\
\hline $\begin{array}{l}\text { Average Pore Volume of } \\
\text { Samples, } m \text { l }\end{array}$ & 15.82 & 16.30 & 14.80 & 11.33 & 15.23 \\
\hline Leaching Rate, $\mathrm{cm} /$ day & $\cdots+\cdots$ & 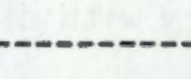 & $-39.80-$ & $\ldots$ & - \\
\hline Particle Density, $\mathrm{g} / \mathrm{cm}^{3}$ & 2.91 & 3.00 & 2.81 & 2.68 & 2.91 \\
\hline Average Bulk Density, $\mathrm{g} / \mathrm{cm}^{3}$ & 1.52 & 1.23 & 1.54 & 1.40 & 1.38 \\
\hline
\end{tabular}

Analys is of the leachate effluents indicates some removal and/or adsorption of ions from the soil/solution system. The ICP results are given in Table 2.2. Effiuent concentrations greater than those of the leaching solution reflect leaching of the ions from the tailings material. Generally, the effluent from the first leach cycle contained higher concentrations of cations and anions than the effluent from later, cycles. In the cases in which the ion concentration increased after leaching, exchange or desorption from the media occurred (e.g., calcium and chloride from the slimes, and silica from the sand). Magnesium concentrations were reduced below influent levels due to exchange or precipitation.

The leaching tests suggest that acidified tailings that are subjected to prolonged leaching will continue to remain acidic for long periods of time. Reduction of contaminant concentrations will be obtained by dilution, but potential for contaminant transport remains high as long as the tailings remain acidic. Direct contact of tailings with ground water would not be desirable. Leaching of tailings by percolation of surface water would need to be minimized to assure that acid ieachate would not eventually reach ground water. 
TABLE 2.2. Chemical Analys is of Leachate Solutions

\begin{tabular}{|c|c|c|c|c|c|c|c|c|c|c|c|c|}
\hline \multirow{2}{*}{$\begin{array}{l}\text { Parameter } \\
\text { Pore Volume }\end{array}$} & \multicolumn{2}{|c|}{ Oewatered Iailiogs } & \multicolumn{2}{|c|}{ Slines } & \multicolumn{2}{|c|}{ Sends } & \multicolumn{2}{|c|}{ Ore } & \multirow[t]{2}{*}{$\begin{array}{l}\text { Mill } \\
\text { Process } \\
\text { Water } \\
\end{array}$} & \multicolumn{2}{|c|}{$\begin{array}{l}\text { Tailings } \\
\text { Slurry }\end{array}$} & \multirow[t]{2}{*}{$\begin{array}{l}\text { Diluted } \\
\text { Tailings } \\
\text { Solution }\end{array}$} \\
\hline & 2.59 & 20.1 & 2.5 & 19.5 & 2.8 & 21.6 & $0-13$ & $13-28$ & & 3.8 & 21 & \\
\hline Leach Cycle & 1 & 6 & 1 & 6 & 1 & 6 & $1-3$ & $4-6$ & & 1 & 6 & \\
\hline pH & 2.3 & 3.6 & 2.4 & 3.4 & 2.4 & 3.7 & 7.7 & 8.0 & 8.1 & 2.3 & 2.5 & 2.5 \\
\hline AI & 299 & 4 & 1050 & 15 & 316 & $<1$ & $<1$ & $<1$ & 0.1 & 319 & 154 & 157 \\
\hline As & 6 & 0.5 & 20 & $<0.1$ & 5.9 & $<0.1$ & $<0.1$ & $<0.1$ & $<0.01$ & 5.6 & 3.1 & 2.2 \\
\hline $\mathrm{Ca}_{\mathrm{a}}$ & 581 & 435 & 559 & 665 & 435 & 14 & 76 & 50 & 53 & 529 & 336 & 123 \\
\hline Cd & 0.4 & $<0.1$ & 0.8 & $<0.1$ & 0.3 & 0.1 & $<0.01$ & $<.1$ & $<0.01$ & 0.3 & 0.2 & 0.2 \\
\hline $\mathrm{Cr}$ & 1.7 & 0.1 & 34.2 & 0.2 & 2.1 & $<0.1$ & 0.13 & 40.1 & $<0.05$ & 1.6 & 0.9 & 0.7 \\
\hline $\mathrm{Cu}$ & 1.0 & $<0.1$ & 2.7 & 0.1 & 0.9 & 0.2 & $<0.01$ & $<.1$ & $<0.1$ & 1.2 & 0.7 & 0.6 \\
\hline $\mathrm{Fe}$ & 636 & 3 & 1490 & 13 & 802 & $<1$ & 0.1 & 0.1 & 0.1 & 668 & 499 & 402 \\
\hline Mg & 364 & $<0.5$ & 1250 & 1.2 & 340 & 0.8 & 22.5 & 15 & 11 & 431 & 188 & 190 \\
\hline Mn & 31 & 0.1 & 112 & 0.1 & 31 & $<0.1$ & 0.03 & 0.04 & 0.01 & 37.4 & 18.1 & 15.2 \\
\hline $\mathrm{Na}$ & 188 & 95 & 444 & 97 & 209 & 101 & 86 & 95 & 91 & 172 & 94 & 75 \\
\hline $\mathrm{Ni}$ & 1.5 & 0.1 & 24.3 & 0.1 & 1.3 & $<0.1$ & $<0.01$ & 0.1 & $<0.01$ & 2.2 & 0.7 & 0.6 \\
\hline Se & $<1$ & 4 & $<1$ & -1 & -1 & $<1$ & $<2.0$ & $<1$ & $<0.1$ & 4 & $<1$ & $<0.5$ \\
\hline si & 28.4 & 22 & 55 & 29 & 16 & 20 & 4.5 & 4.2 & 3.5 & 81 & 66 & 58.4 \\
\hline Sr & 4.4 & 1.6 & 5.2 & 2.7 & 4.5 & 0.1 & 1.1 & 0.6 & 0.9 & 4.9 & 3 & 2.6 \\
\hline Ih & 1.5 & $<1$ & 7 & $<1$ & 1.8 & $<$ & 2.2 & $\therefore 1$ & $<.1$ & 2.7 & 1.4 & 1.7 \\
\hline $2 n$ & 6.4 & 0.9 & 17.1 & 0.7 & 5.3 & 1.0 & 0.2 & 0.4 & 0.05 & 6.7 & 2.8 & 1.8 \\
\hline $\mathrm{SO}_{4}$ & 6667 & 1171 & 16,000 & 1858 & 6154 & 200 & 240 & 179 & 181 & 7083 & 4177 & 3889 \\
\hline $\mathrm{Cl}$ & 126 & 31 & 21 & 32 & 125 & 32 & 29 & 27 & 36 & 300 & 76.5 & 75 \\
\hline
\end{tabular}




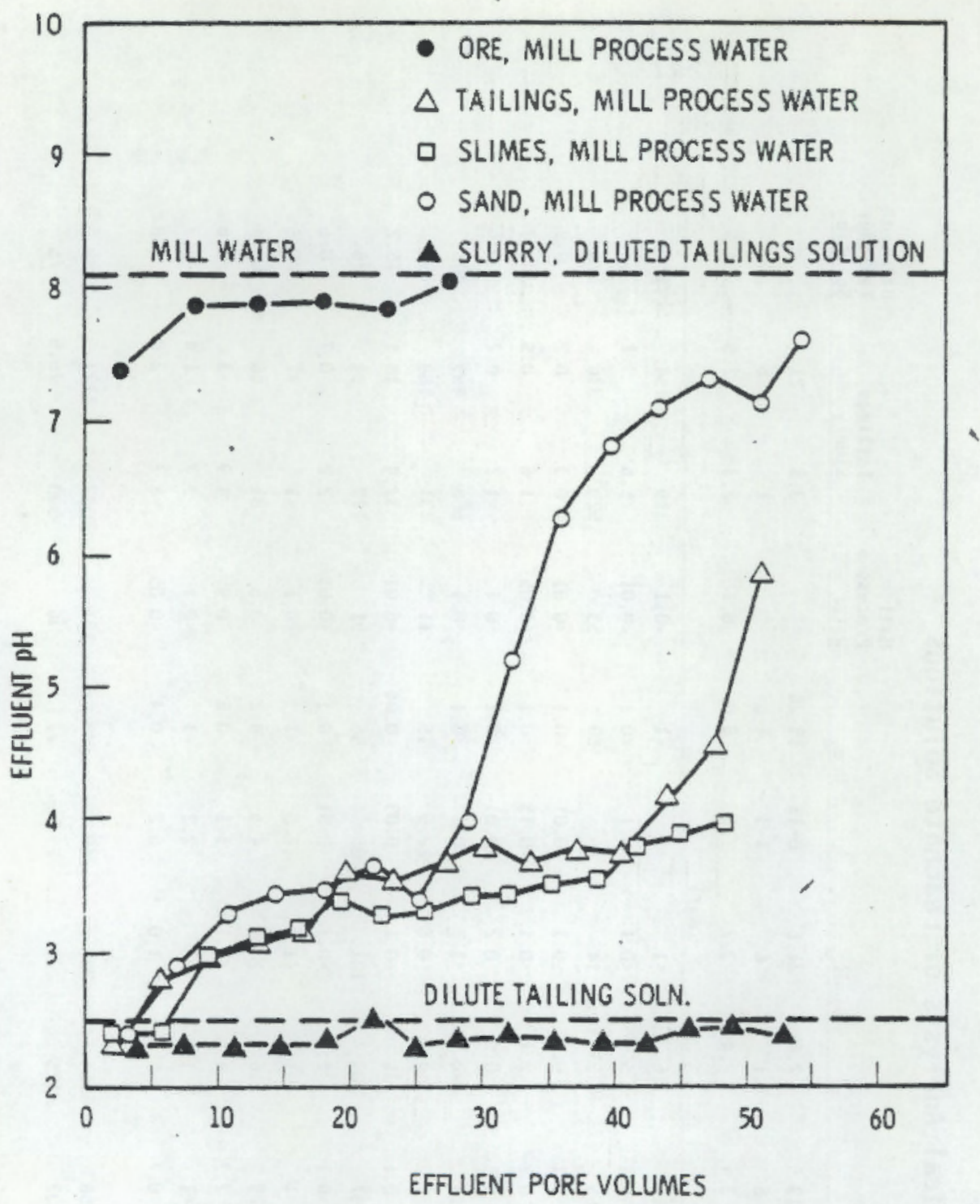

FIGURE 2.1. Changes in Effluent pH Due to Leaching 


\subsection{ATTENUATION STUDIES}

\section{ATTENUATION OF CONTAMINANTS}

Attenuation studies were designed to determine the ability of the Morton Ranci sediment samples to retard the movenent of hazardous materials into the surrounding soil and water systems from disposed tailings. Movement is retarded by adsorption on the soil media, or by precipitation within the system. An element's affinity for movement through media can be estimated by measurement of its distribution coefficient (Kd). Kd is defined as the ratio of the amount of solute (heavy metal or radionuclide, etc.) sorbed on the solid surfaces of the test material to the amount of solute remaining in solution. Low $K d$ values indicate movement while high Kds reflect retardation. For transport calculations, Kd values equated to zero indicate transport at the same rate as water.

Various factors affect $K d$ values. Mineralogy and surface area of the solid sample are.very influential. Parts of the solid may be highly selective in sorbing specific constituents and result in abnormally high Kd values. The presence of calcite or dolomite affects solution pH and composition, which influence $\mathrm{Kd}$ values. Surface area is a function of the solid's mineralogy, particle size distribution, and method of crushing. As surface area of a solid increases, $\mathrm{Kd}$ values oftentimes also increase. The composition of the contacting solution is also important. Sorption of multivalent elements is dependent on the oxidation state of the consituent, which is affected by solution-solid pH-Eh values. The concentration of salts within the solution and entrained salts also affect sorption. Sorption coefficients measured using high salt solutions are often low due to the additional ions competing for the sorption sites. The method and rigor of shaking samples determines whether the solid is broken into small particles. These "fines" can bias Kd values both high and low. Surface area increases with the production of fines, causing higher $K d$ values, while fines not removed from the solution prior to counting can contribute to lower Kd values. Solution:soil ratio affects Kd values in its relationship to the amount of fines. The effect of fines is not as evident in samples with high solution:soil ratios as it is in samples with 
lower solution:soil ratios (Barrow and Shaw 1979). Other factors affecting Kd values are temperature and pressure, which influence the solubility of some elements.

It was proposed that leachate from the previous studies be used in the attenuation studies. The studies to date were performed with undiluted tailings solution to represent the worst condition that could be encountered, that in which solution is not separated from the tailings and is allowed to sit without treatment. Neutralization of the tailings solution was also performed to see its effects on attenuation by the Morton Ranch materials.

Attenuation studies on the Morton Ranch materials were performed using batch distribution coefficient $(K d)$ tests. In these tests, a known volume of tailings solution contacted a known amount of clay liner material, overburden, or sandstone. After ten days the solution was separated by centrifugation and analyzed. Kd values were then calculated from the ratio of the tracer (constituent) concentration in the sample to the concentration remaining in solution. The concentration in the sample is the difference between the starting solution concentration and that remaining in solution at the end of the contact period.

\section{TESTS RESULTS}

After being contacted with untreated tailings solution, the clay liner, overburden, and sandstone did not remove significant amounts of the nonradioactive elements from solution. The high salt concentration and acidity of the tailings solution accounts for the low sorption. In contrast, the radionuclides ${ }^{238} \mathrm{U},{ }^{226} \mathrm{Ra},{ }^{230} \mathrm{Th}$, and ${ }^{210} \mathrm{~Pb}$ were sorbed by each of the Morton Ranch materials in varying degrees (Table 3.1). More $210_{\mathrm{Pb}}$ was removed from solution than the other nuclides, with the clay liner removing the most.

Kds for the neutralized solution samples showed greater sorption by the clay liner than the Kds from the untreated solution (Tables 3.2 and 3.3). Higher values were calculated but there were wide differences between samples, as evidenced by the high coefficients of variation. Sorption was greater for radium and thorium, and lower for uranium and lead than for the untreated solution. This apparent decrease in sorption is a function of the lower 
TABLE 3.1. Batch Kd Values $(\mathrm{ml} / \mathrm{g})$ Using Untreated and Neutralized Uranium Mill Tailings Solution for 10-Day Contact Periods $(\mathrm{ml} / \mathrm{g}$ ) with Morton Ranch Materials. Mean Values of Duplicate Samples.

\begin{tabular}{|c|c|c|c|}
\hline & Clay Liner & Overburden & Sandstone \\
\hline Element & 2.4 & 2.2 & 2.2 \\
\hline$U-238$ & 1.3 & 1.0 & 1.7 \\
\hline Th-230 & 1.2 & 1.1 & 1.9 \\
\hline Ra-226 & 13 & 10 & 18 \\
\hline$P b-210$ & 1848 & 13 & 68 \\
\hline
\end{tabular}

concentrations due to neutralization. The untreated and neutralized solution compositions used in the tests, given in Table 3.2, are markedly different. Neutralization using $\mathrm{NaOH}$ caused the precipitation of most of the constituents, especially Al, $\mathrm{Fe}, \mathrm{Mn}, \mathrm{Si}$, and the radionuclides. Comparison of the neutralized blank values with MPC levels given in Tables 1.3 and 1.4 show concentrations were reduced below MPC for $\mathrm{Cu}, \mathrm{Zn}, \mathrm{U}, \mathrm{Th}$, and $\mathrm{Pb}$. Other concentrations were reduced up to three orders of magnitude.

The determined $K d$ values in Table 3.1 reflect both sorption and precipitation reactions, with the main attenuation process being precipitation or scavanging of trace metals by formation of unsoluble hydrous oxides (see Section 4).

The effect of neutralization was significant removal of elements. By reducing concentrations, the process of attenuation was enhanced. When Kds were calculated using the blank values from the untreated solutions and the neutralized $\mathrm{clay}$ liner values, $\mathrm{Xd}$ values increased considerably. These effective values due to neutralization are reported in Table 3.3. By reducing the concentrations of hazardous materials, leachate from disposed tailings poses a smaller threat to the surroundings. 
TABLE 3.2. Data Used in Calculating Batch Kd Values

$\frac{\text { Parameter }}{\text { Sample } \mathrm{pH}} \frac{\frac{\text { Untreated Tailings Solution }}{\text { Blank }}}{2.1} \frac{\text { Clay Liner }}{2.4} \frac{\text { Neutralized Tailings Solution }}{\frac{\text { Blank }}{4.9}} \frac{\text { Clay Liner }}{7.7}$

ICP Analysis, (mg/l)

$\begin{array}{lccrr}\text { Al } & 663(26)^{(a)} & 687(21) & 0 \ldots & 0 \ldots \\ \text { As } & 6.2(1.9) & 7.4(1.7) & 1.2(23) & 3.4(4.8) \\ \text { Ca } & 586(59) & 616(62) & 446(13) & 443(13) \\ \text { Cd } & 3.4(1.3) & 3.2(0.5) & 0.4(0.5) & 0.3(0.4) \\ \text { Cr } & 3.0(0.2) & 3.1(0.2) & 0.1(0.2) & 0.2(0.2) \\ \text { Cu } & 3.0(0.7) & 3.1(0.5) & 0.2(0.2) & 0.4(0.4) \\ \text { Fe } & 2,075(104) & 2,046(102) & 0.3(0.3) & 1.0(0.6) \\ \text { Mg } & 717(36) & 770(31) & 610(12.2) & 603(12) \\ \text { Mn } & 68(3.0) & 68(2.7) & 18(0.7) & 13(0.6) \\ \text { Na } & 308(22) & 315(16) & 5,118(204) & 5,050(151) \\ \text { Ni } & 26(19) & 3.5(1.0) & 1.4(1.7) & 0.4(0.1) \\ \text { Si } & 264(34) & 299(33) & 3.1(3.5) & 9.3(1.5) \\ \text { Sr } & 12(0.4) & 14(0.6) & 9(0.4) & 10(0.3) \\ \text { Th } & 9(1.8) & 9(2.0) & 0.4(0.5) & 0.4(0.6) \\ \text { Zn } & 9(1.3) & 11(1.0) & 0.8(0.6) & 0.7(0.6)\end{array}$

Radiochemical Analysis, (pCi/l)

$\begin{array}{ccccc}\text { U-238 } & 9,685(194) & 247(52) & 26(0.8) & 29(9.9) \\ \text { Ra-22.6 } & 13,198(264) & 12,632(126) & 44(7.9) & 17(9.5) \\ \text { Th-230 } & 227,252(2272) & 218,233(2182) & 595(77) & 85-- \\ \text { Pb-210 } & 2,252(676) & 1,583(317) & 28(20) & 28(20)\end{array}$

(a) Number in parentheses is standard deviation 
TABLE 3.3. Effective Kd Values Due to Neutralization

\begin{tabular}{|c|c|c|}
\hline \multirow[b]{2}{*}{ Element } & \multicolumn{2}{|c|}{$\begin{array}{c}\text { Morton Ranch } \\
\text { Clay Liner, } \mathrm{PH} \\
\end{array}$} \\
\hline & 2.2 & 7.7 \\
\hline Al & 0 & 19,860 \\
\hline As & 0 & 25 \\
\hline $\mathrm{Cd}$ & 0 & 310 \\
\hline $\mathrm{Cr}$ & 0 & 420 \\
\hline $\mathrm{Cu}$ & 0 & 195 \\
\hline $\mathrm{Fe}$ & 0.4 & 62,220 \\
\hline Mn & 0 & 127 \\
\hline $\mathrm{Ni}$ & 0 & 165 \\
\hline Si & 0 & 822 \\
\hline $\mathrm{Sr}$ & 0 & 6 \\
\hline $\mathrm{Zn}$ & 0 & 356 \\
\hline U-238 & 1.3 & 23,292 \\
\hline Th-230 & 1.2 & 80,189 \\
\hline $\mathrm{Ra}-226$ & 13 & 2,383 \\
\hline $\mathrm{Pb}-210$ & 1848 & 10,005 \\
\hline
\end{tabular}




\subsection{CLAY LINER TESTS}

$\underline{\text { INTRODUCTION }}$

The Nuclear Regulatory Commission (USNRC 1979b) has considered a number of options for tailings management at the Morton Ranch mill site. Most of . these options include a clay liner for seepage control. The clay liner is to be constructed from on-site materials. These materials must have the proper characteristics and be placed in such a way that their presence as a liner either eliminates seepage of toxic materials into the ground water system or reduces it to the "maximum extent reasonably achievable". The Environmental Protection Agency (USEPA 1978) has proposed a number of criteria for "soil" liner materials for hazardous waste containment. These criteria include certain textural, particle-size, $\mathrm{pH}$, and permeability specifications (Table 4.1). A maximum permeability of $1 \times 10^{-7} \mathrm{~cm} / \mathrm{s}$ is required for liner material with the additional specification that the permeability is not adversely affected by the anticipated waste.

\section{TABLE 4.1. EPA Soil Liner Criteria (USEPA, 1978)}

1. Soil classification must be $\mathrm{CL}, \mathrm{CH}, \mathrm{SC}$ or $\mathrm{OH}$ under the Unified Soil Classification System

2. Allow greater than 30 percent passage through a No. 200 sieve

3. Have a liquid limit equal to or greater than 30 units

4. Have plasticity greater than or equal to 15 units

5. Have a pH of 7 or higher

6. Have a permeability not adversely affected by anticipated waste.

The concern that the tailings solution could interact with the clay liner and in time cause liner failure (i.e., result in an increase in permeability) has prompted an investigation into possible mechanisms of clay liner failure at the Morton Ranch site. 
Clay dispersion, clay dissolution, volume change, and change in clay wetability have all been identified as mechanisms that can act to cause failure of a clay liner. A detailed review of these mechanisms is given by Brown and Anderson (1980). For pit disposal of tailings, where the liner is permanently buried and the tailings solution is inorganic, the oniy mechanisms that could act to cause failure are clay dispersion and clay dissolution. Laboratory tests were designed to evaluate clay dispersion, clay dissolution, and time dependence of clay permeability for the Morton Ranch clay liner materials.

\section{MATERIALS AND METHODS}

Clay liner material taken from the 1704 pit at Morton Ranch (Figure 2.13 in USNRC, 1979a, Figure 4.1) was used in all tests. Physical and chemical characteristics for this material are described in Table 1.1. For comparison purposes, Wyoming bentonite and saline seal (sodium-treated Wyoming) were obtained from a commercial vendor (American Colloid Co., Skokie, I1linois) and were tested along with the Morton Ranch clay liner material for mineralogical changes occurring after contact with tailings solution. Details of specific methods are discussed in the following section on mineralogy. ASTM (1978) methods were used to evaluate clay texture, fineness, liquid limit and plasticity. Clay dispersion criteria followed methods of Sherard et al. (1976). $X$-ray analysis, scanning electron microscopy, and $X$-ray fluorescence were all used to evaluate the physical and mineralogical changes in the clay liner material subjected to contact with tailings solution. Permeability tests were run on the clay liner and overburden using both the tailings solution and a synthetic solution containing equivalent macro-ion constituents but no radionuclides. Flow through the clay liner was enhanced by using a pressurized permeameter designed to accommodate acid leach solutions. Details of packing procedures and cell volumes are given in the section on permeability. 


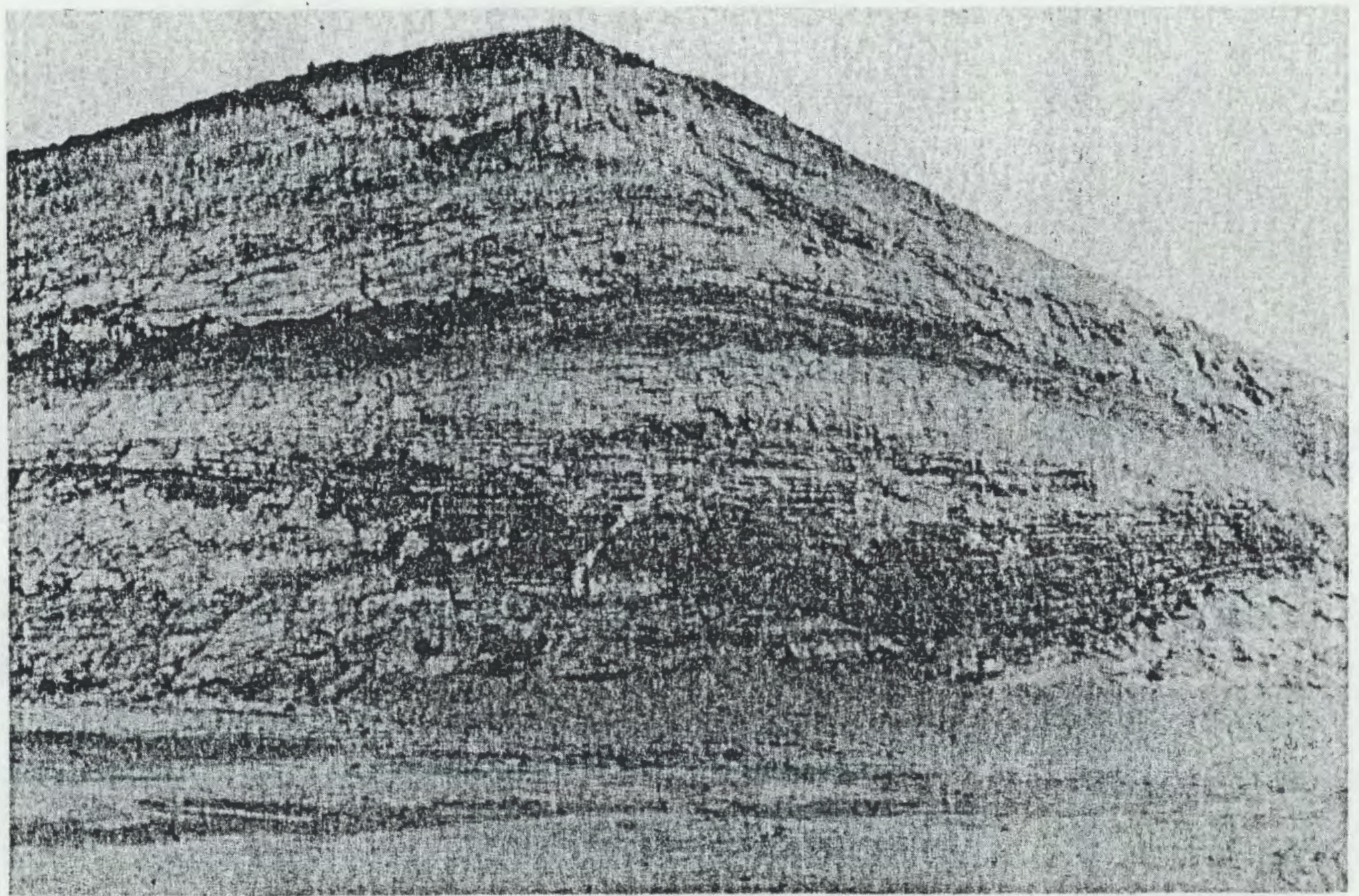

F1GURE 4.1. 1704 Pit at Morton Ranch. Clay liner material taken from shale and siltstone material similar to that seen exposed on pit wall. 
RESULTS AND DISCUSSION

\section{Liner Criteria}

Table 4.2 shows the results of the measurements made to test the Morton Ranch clay liner against EPA criteria. The data indicate that all measureable parameters for the Morton Ranch clay liner meet the EPA liner criteria. Extended leaching of the liner with tailings solution had no apparent adverse effect on the clay liner permeability. The permeability results are discussed in detail in a later section.

TABLE 4.2. EPA Criteria and Morton Ranch Clay Liner Characteristics

\section{Characteristic}

1. Soil Classification (Unified Soil Classification System)

2. Fineness

3. Liquid Limit

4. Plasticity

5. $\mathrm{pH}$

6. Permeability $(\mathrm{cm} / \mathrm{s})$

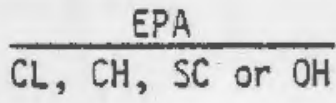

$\geq 30 \%$ thru $73 \mu \mathrm{m}$ screen (200 mesh)

$>30$

$\geq 15$

$\geq 7$

$10^{-7}$
Morton Ranch Liner

CL (clayey silt)

$95 \%$

43

21

8

$<5 \times 10^{-8}$

Dispersion Test Results

Results of the initial tests for clay dispersion by the crumb test gave the clay liner a dispersion rating of 1 to 1.5. This rating indicates that the clay is nondispersive. Gee et al. (1978) have previously observed that in this dispersion range, crumb tests correlate well with the pinhole test (Sherard et al. 1976), hence, the more detailed pinhole test was not run.

Testing of the soil solution using criteria established by Sherard et al. (1976) indicated that the tailings solution would not contribute to the dispersion. Solution chemistry data for tailings solution, diluted tailings solution and leachate from tailings using mill process water are plotted in Figure 4.2. All data indicate that the solution would have a non-dispersive 


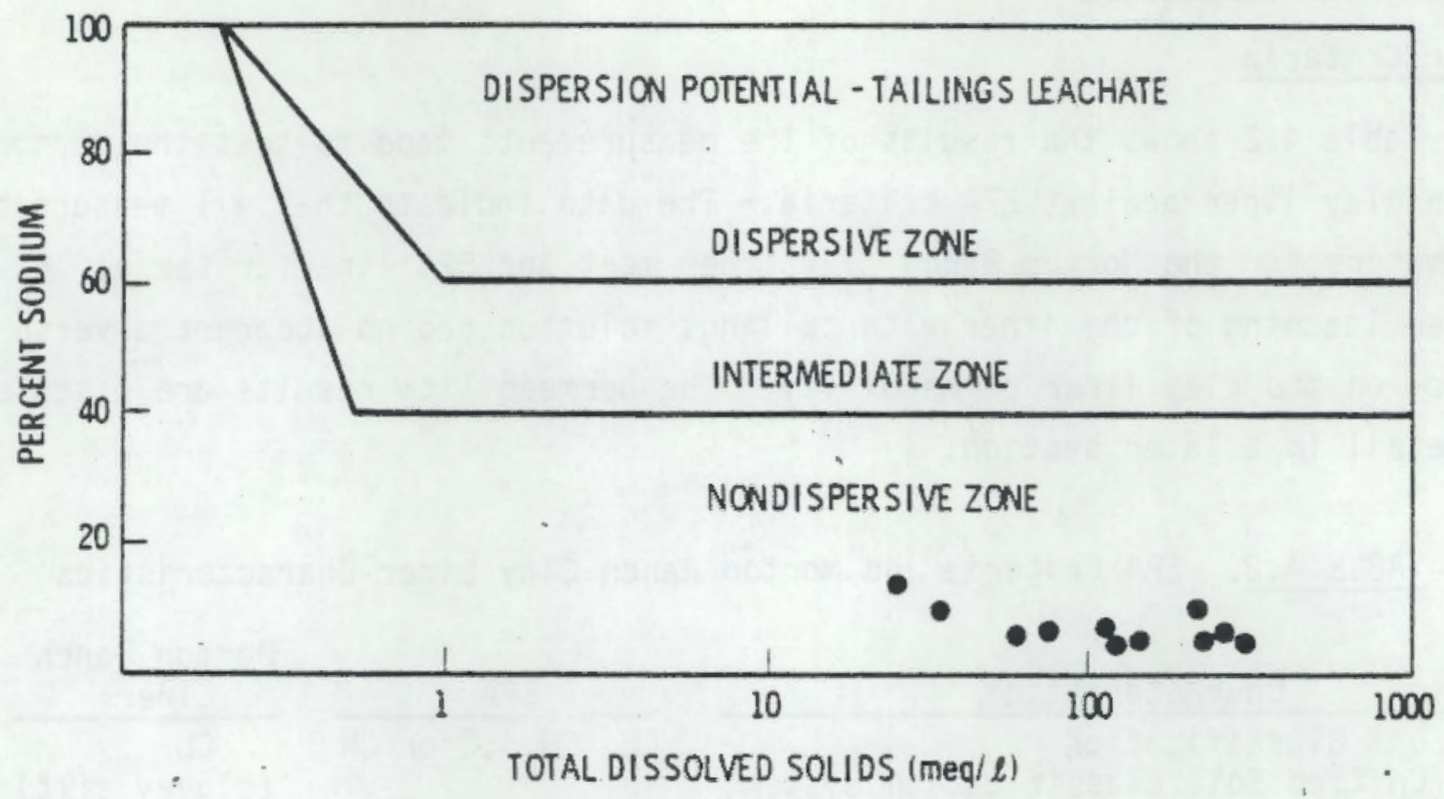

FIGURE 4.2. Solution Composition of Tailings Solution and Leachate from Tailings Related to Dispersion Potential Criteria Established by Sherard et al. 1976

influence on the clay material. The percent sodium in the soil solutions is less than 15 in all cases. Gee et al. (1978) have previously observed that when the percent sodium is less than 20 , no dispersion of the sample is observed using a pinhole test. Since neither the clay material nor the tailings solution has any dispersive tendencies, we conclude that clay dispersion cannot be a mechanism for failure of the clay liner even after extended time.

Minerological Tests

Results from total elemental analyses by $X$-ray fluorescence are presented in Table 4.3. There was no significant decrease in silicon or aluminum, as might be expected if mineral dissolution were occurring. There was a consistent increase in $\mathrm{Fe}_{2} \mathrm{O}_{3}$ and $\mathrm{FeO}$ content, which suggests that secondary ion minerais may have been forming during the 90 -day test period. The most significant change in composition was the $\mathrm{Na}_{2} \mathrm{O}$ reduction after treatment for the bentonite and saline seal. The relative change in sodium for the saline seal suggests that some of the effectiveness of the sodium saturation of this liner 
TABLE 4.3. Total Elemental Analysis of Morton Ranch Clay Liner, Bentonite, and Saline-Seal Liner Before and After Treatment with Tailings Solution

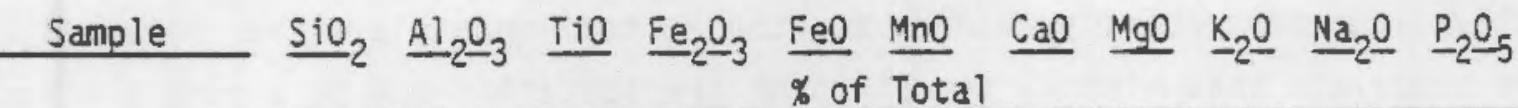

Untreated

$\begin{array}{llllllllllll}\text { Clay Liner } & 73.0 & 16.4 & 0.8 & 2.0 & 2.3 & 0.02 & 1.0 & 1.3 & 2.5 & 0.7 & 0.07 \\ \text { Bentonite } & 66.9 & 22.1 & 0.2 & 1.9 & 2.2 & 0.02 & 1.2 & 2.2 & 0.6 & 2.6 & 0.2 \\ \text { Saline Seal } & 67.6 & 19.9 & 0.2 & 2.0 & 2.3 & 0.05 & 1.6 & 1.5 & 1.0 & 3.3 & 0.4 \\ \text { Treated (a) } & & & & & & & & & & & \\ \text { Clay Liner } & 72.3 & 15.6 & 0.8 & 2.9 & 3.3 & 0.02 & 0.8 & 1.2 & 2.6 & 0.5 & 0.1 \\ \text { Bentonite } & 66.4 & 22.6 & 0.2 & 2.6 & 3.0 & 0.03 & 1.0 & 2.3 & 0.6 & 1.1 & 1.2 \\ \text { Saline Seal } & 67.4 & 19.8 & 0.8 & 2.7 & 3.1 & 0.04 & 1.4 & 1.8 & 1.0 & 1.6 & 0.4\end{array}$

(a) 5:1 (tailings solution:solid) sample shaken for 90 days at room temperature

TABLE 4.4. Identified Clay Minerals and Relative Abundance Determined by $X$-Ray Diffraction Analysis on Liner Samples Material Treated as Specified in Table 4.3

Inter-

Sample Smectites Kaolins Chlorites grade Quartz Feldspars Micas

Morton Ranch

Clay Liner

untreated

treated

$+$

$+$

Bentonite

untreated

treated
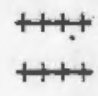

Saline Seal

untreated

treated

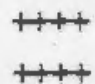

Relative Abundance

$+=$ High

++ = Moderate

$++=$ Low

$+=\operatorname{Trace}$

- = Absent 
material might be lost due presumably to exchange with hydrogen and other competing ions. It appears that if minor amounts of dissolution are occurring, mineralization or precipitation reactions are aiso occurring at the same time, which tend to maintain similar total elemental compositions. We conclude from these observations that mineral dissolution is not a significant factor in clay liner permeability changes for the Morton Ranch clay liner material, and we speculate that mineral formation or precipitation may be a possible factor in actually causing permeability decreases.

\section{$\underline{X-r a y}$ Diffraction}

$X$-ray diffraction analyses of the materials analyzed before and after contact with mill-tailings solution showed only minor changes in the mineralogy of a few sample mineral constituents. Table 4.4 summarizes the minerals present in each of the studied samples. Their relative abundance before and after contact with uranium mill tailings is also shown semiquantitatively. The predominant change in mineralogy occurs within the smectite, intergrade and hydrous mica whereby contact appears to reduce the amount of each mineral. Figures $4.3,4.4$ and 4.5 show generalized $X$-ray diffraction patterns of the composite clay liner, bentonite and saline seal, respectively, before and after contact. Each of these diffraction patterns shows some degradation of the smectite and intergrade, as distinguished by a broadening of the basal spacing of the peaks and by a reduction in peak intensity. Peak intensity reduction typically is diagnostic of a reduction of mineral crystallinity. Chlorite, feldspars and quartz minerals were not found to significantly change in relative abundance or crystallinity when subjected to contact with uranium mill tailings solution.

In general, within the limits of experimental error and the semiquantitative nature of $X$-ray diffraction data, only small mineralogical changes of layer lattice clay minerals were observed. These mineralogical changes are probably a direct result of some dissolution of minerals by the sulfuric acid present in the mill tailings solution, ion exchange of solution constituents, and precipitation reactions whereby the clay minerals are partially destroyed or transformed into other clay minerals. 


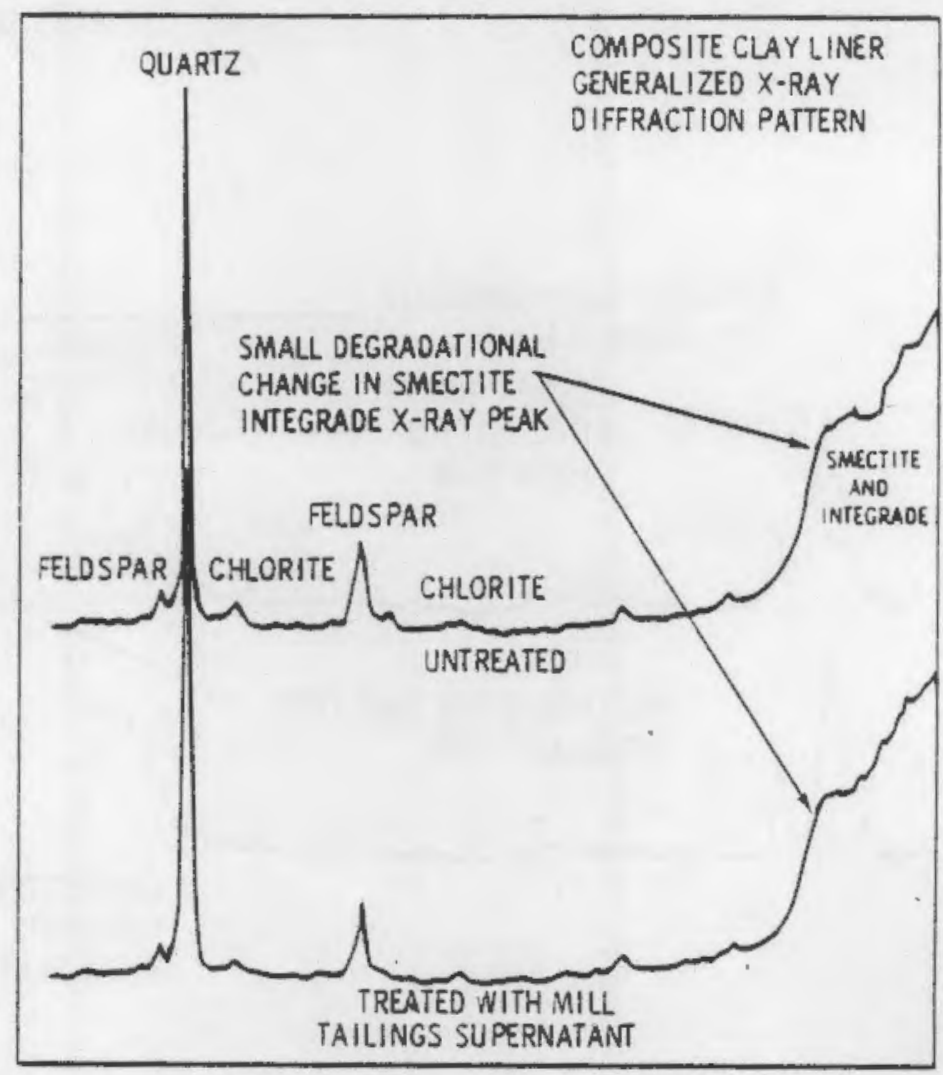

FIGURE 4.3. X-ray Diffraction of the <10 un Fraction of Morton Ranch Clay Liner Material

\section{Scanning Electron Microscopy}

Scanning electron microscopy (SEM) was used to determine if there was any change of mineral surface morphology of bentonite, saline seal, and the Morton Ranch clay liner materials when contacted with the tailings solution. Scanning electron photomicrographs were taken at magnifications of 5,000 to 10,000 for each of the treated and untreated samples. Photomicrographs of the composite clay liner, bentonite, and the saline seal are shown in Figures $4.6 \mathrm{ab}$, $4.7 \mathrm{ab}$ and $4.8 \mathrm{ab}$, respectively.

Photomi crographs $4.6 \mathrm{~b}, 4.7 \mathrm{~b}$ and $4.8 \mathrm{~b}$, which show the surface morphology of the <10um fraction of treated materials, show only a little evidence of structural degradation. Figures $4.6 a, 4.7 a$, and $4.8 a$ show the surface morphology of the same materials not subjected to treatment. The untreated materials generally appear somewhat more crystalline, in that the clay mineral 


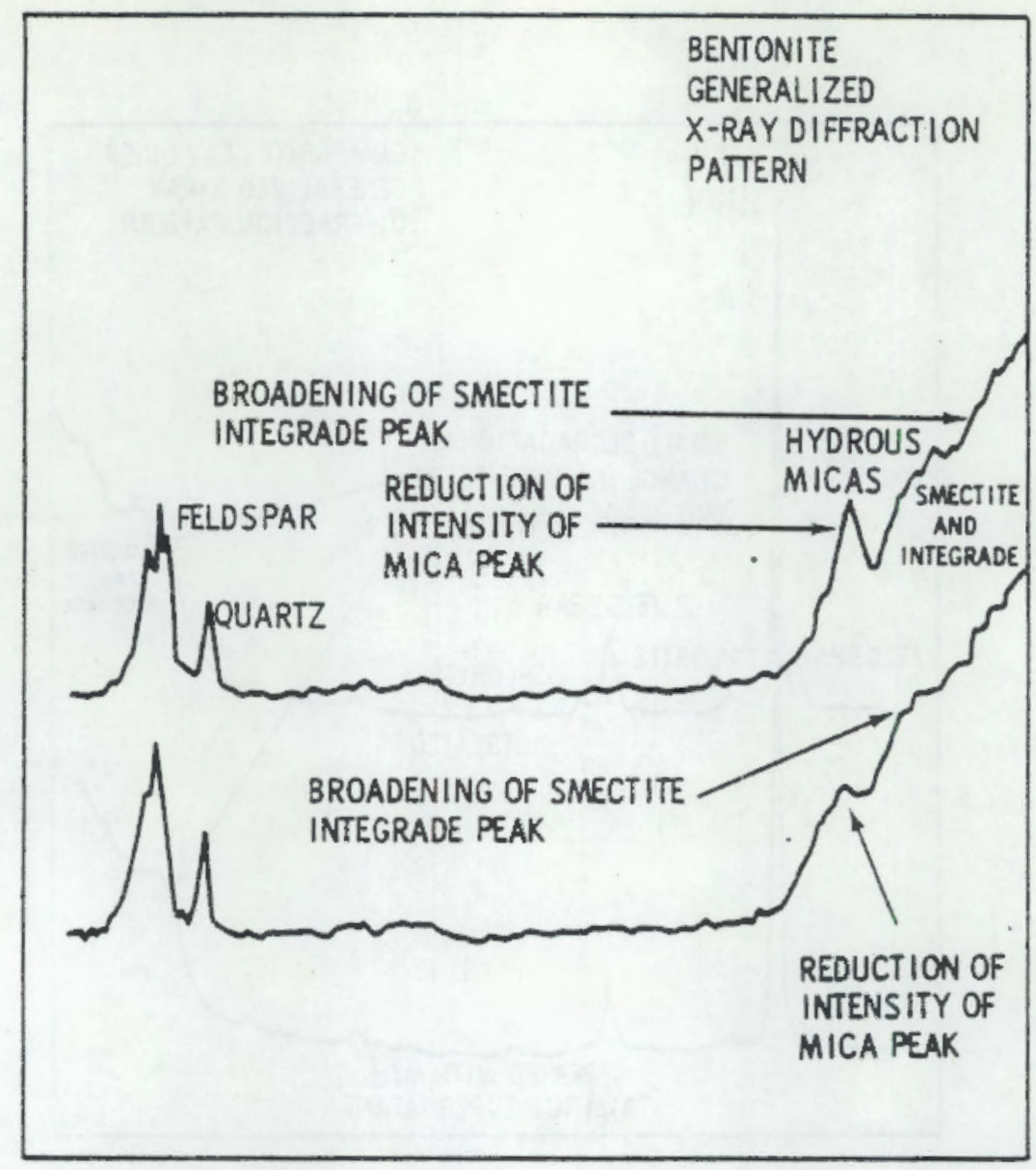

FIGURE 4.4. X-ray Diffraction of the $<10 \mu \mathrm{m}$ Fraction of the Bentonite Clay Liner Material

particles have better edge contrast in the photomicrographs. The untreated particles also show a somewhat definitive texture, whereas the treated particles tend to show a texture diagnostic of a reduced crystallinity. This also could be a result of secondary mineral formation on the clay surfaces due to precipitation reactions.

The SEM photomicrographs tend to indicate that acid within the uranium mill tailings may have slightly degraded the crystal structure of the $<10 \mu \mathrm{m}$ fraction of the liner materiais studied. However, no drastic changes were observed for the 90-day test period, suggesting that if structural breakdown is occurring, it is doing so at a very slow rate. Additional SEM analyses will be run for samples that have been treated for over 180 days to determine if extended contact time results in further degradation. 


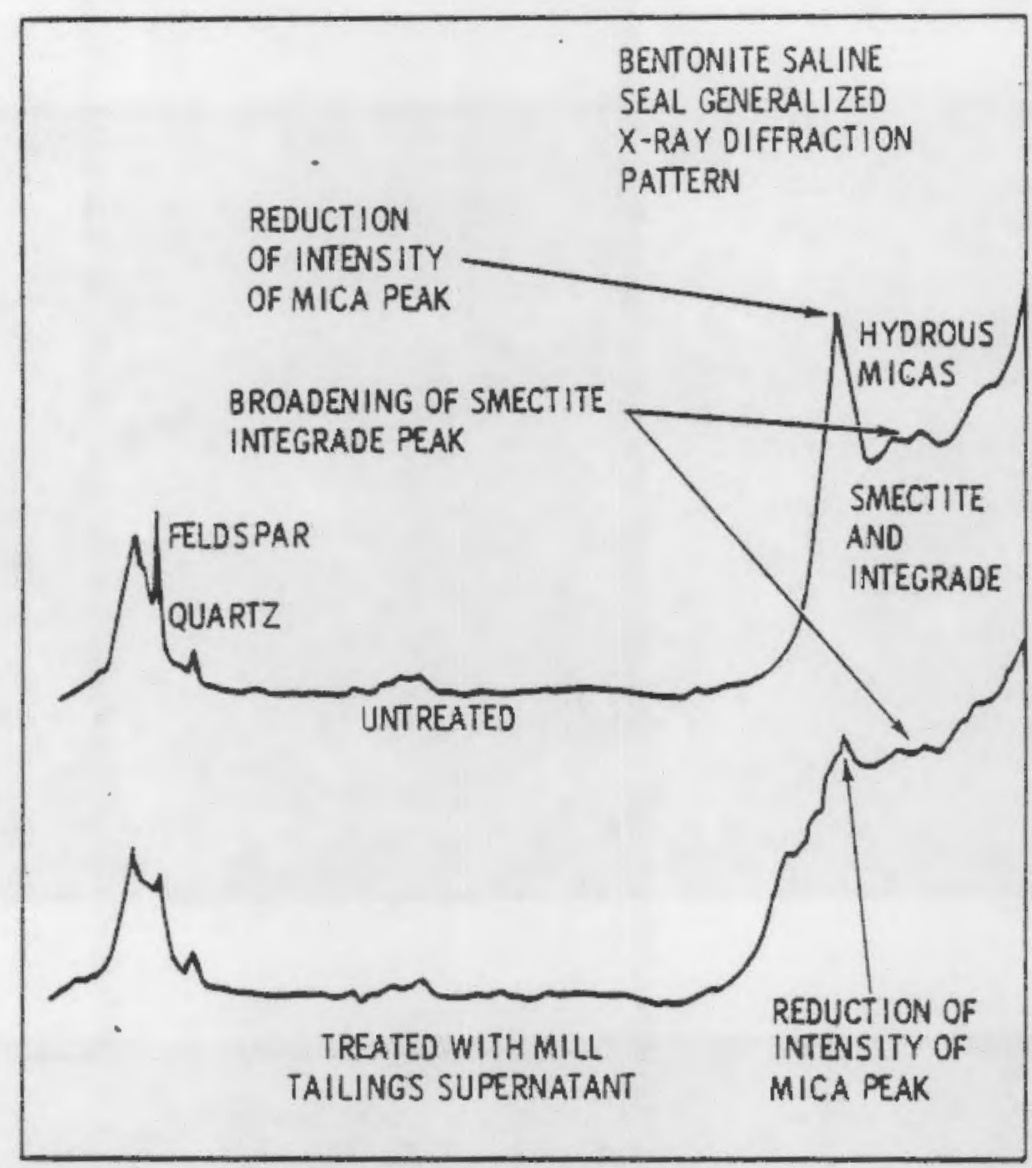

FIGURE 4.5. X-ray Diffraction of the $<10 \mu \mathrm{m}$ Fraction of the Saline Seal Clay Liner Material

Extrapolation of the results of these mineralogical tests to clay liner stability can only be indirect. The mineralogy tests indicate that no drastic or substantial changes are occurring due to contact of the clay liner materials with the acid taflings solution. The treatment optimized the contact of solution-to-solid surfaces (5:1 ratio), hence, if dissolution were a serious problem, it should have been observed in the treated samples. We conclude, therefore, that clay distribution, even if occurring, should not contribute to Morton Ranch clay liner failure since reaction rates for tailings solution at pH 2 appear to be very slow. 

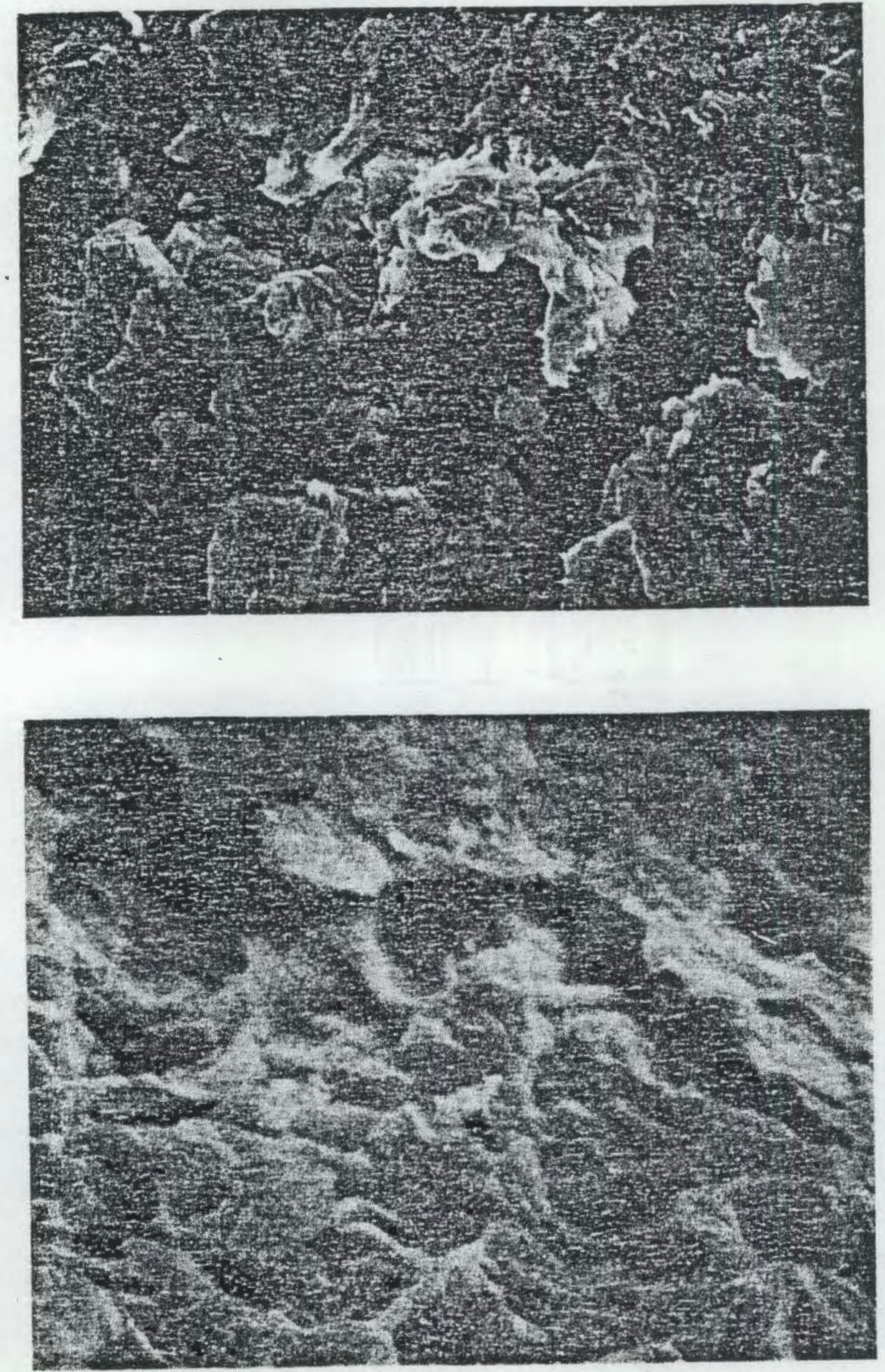

FIGURE 4.6a (upper) and b (lower). SEM Photomicrograph of Composite Clay Liner (magnification of $4 a=5,000 ; b=10,000$ ) 

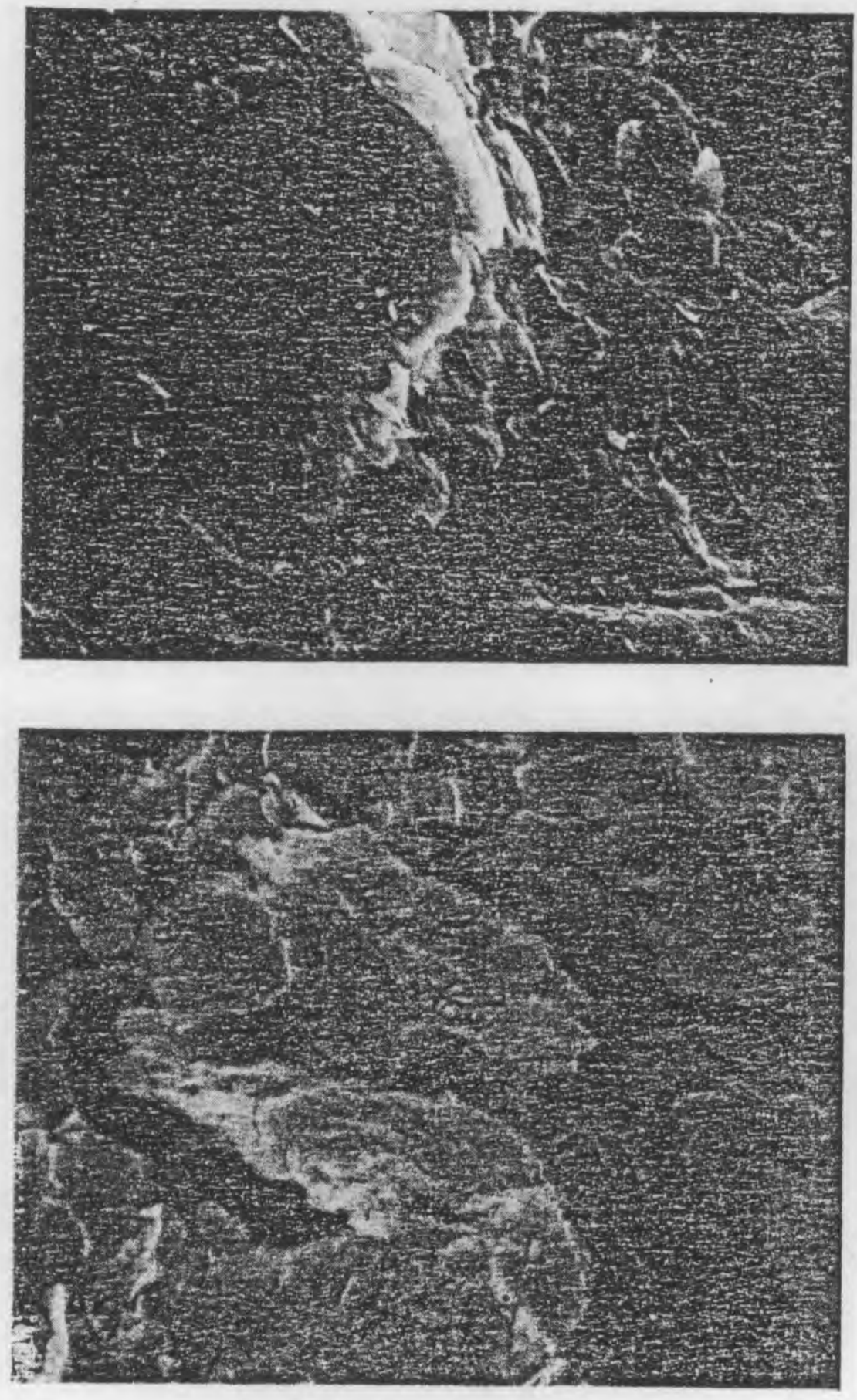

FIGURE 4.7a (upper) and $b$ (1ower). SEM Photomicrograph of Bentonite (magnification of $4 \mathrm{a}=10,000 ; b=10,000$ ) 

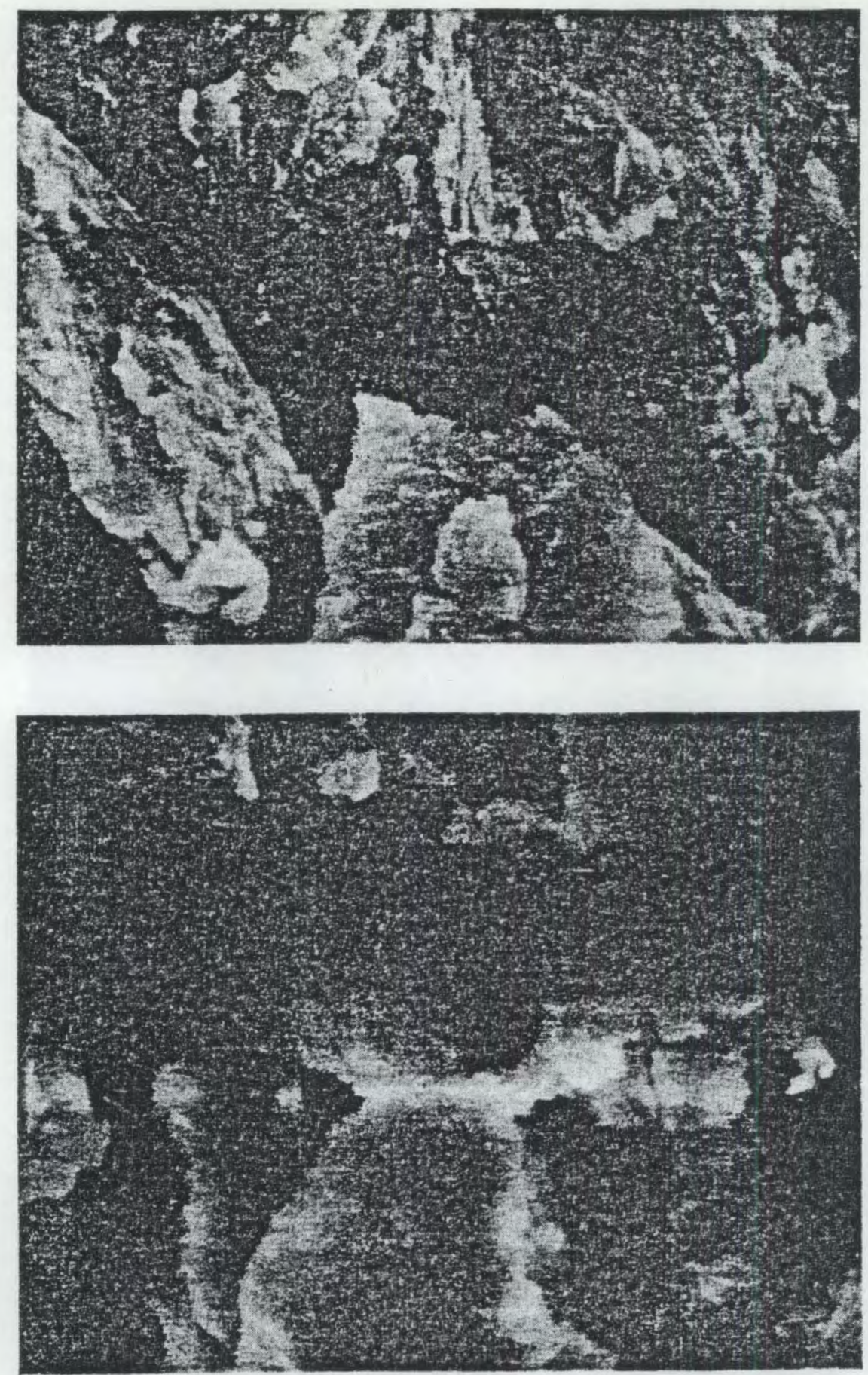

FIGURE 4.8a (upper) and b (lower).

SEM Photomicrograph of Bentonite Saline Seal

(magnification of $4 a=10,000 ; b=10,000$ ) 


\section{Permeability Tests}

Morton Ranch clay liner and overburden materials were used in the tests. These materials were compacted into cylindrical cells with an approximate volume of $90 \mathrm{~cm}^{3}$. The method used for compaction was a variation of the sliding-weight tamper method (ASTM 1978). The data for each cell are given in Table 4.5.

TABLE 4.5. Physical Data for Test Materials

\begin{tabular}{|c|c|c|c|c|c|c|c|c|c|}
\hline Matarial & Cell No. & $\begin{array}{c}\text { Cell } \\
\text { Diameter } \\
\text { (cm) } \\
\end{array}$ & $\begin{array}{l}\text { Length } \\
\text { (cm) }\end{array}$ & $\begin{array}{l}\text { Volunge } \\
(\mathrm{cm} 3) \\
\end{array}$ & $\begin{array}{r}\text { Initial } \\
\text { Moisture } \\
\text { (wts) } \\
\end{array}$ & $\begin{array}{c}\text { Samole } \\
\text { Weight } \\
\text { (g) } \\
\end{array}$ & $\begin{array}{c}\text { Buik } \\
\text { Density } \\
\text { (g/cm }\end{array}$ & 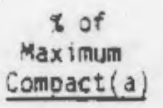 & $\begin{array}{c}\text { Pore } \\
\text { Volune }(y) \\
\left(\mathrm{cm}^{3}\right) \\
\end{array}$ \\
\hline Clay Liner & 1 & 5.03 & 4.50 & 89.6 & 9.6 & 159.7 & 1.78 & 97 & 31.6 \\
\hline Clay Liner & 2 & 5.00 & 4.60 & 90.3 & 9.0 & 157.8 & 1.75 & 95 & 32.8 \\
\hline Clay Liner & 3 & 5.00 & 4.67 & 91.7 & 10.5 & 155.6 & 1.70 & 92 & $35 .:$ \\
\hline Clay biner & 4 & 4.98 & 4.50 & 87.35 & 10.5 & 157.7 & 1.80 & 98 & 31.4 \\
\hline Clay Liner & 5 & 4.98 & 4.50 & 87.8 & 10.5 & 154.2 & 1.76 & 95 & 32.7 \\
\hline Clay Liner & 6 & 4.98 & 4.50 & 87.8 & 10.5 & 156.4 & 1.78 & 97 & 31.9 \\
\hline Over burden & 7 & 4.98 & 4.60 & 90.1 & 12.5 & 171.4 & 1.90 & 95 & 26.1 \\
\hline Overburden & 8 & 4,95 & 4.60 & 38.5 & 12.5 & 169.6 & 1.92 & 96 & 24.9 \\
\hline Overburden & 9 & 5.05 & 4.55 & 91.5 & 12.5 & 174.0 & 1.90 & 95 & 26.2 \\
\hline
\end{tabular}

(a) Maximun compaction was detarmined for both materials by a standard procter test. Maximum compaction for the clay liner naterial was $1.84 \mathrm{~g} / \mathrm{cm}^{3}$, and the overburden, naterial was $2.00 \mathrm{~g} / \mathrm{cm}^{3}$.

(b) Pore Volume a yolmune of void space in total sangle volume $\left(\mathrm{cm}^{3}\right)$.

Each cell was packed to about $95 \%$ of maximum compaction. All of the cells, with the exception of Cell 1, were saturated with ground water. Cell 1 was contacted initially with a synthetic tailings solution. Constant head permeability tests were then run on all cells. Cells 1, 2, and 3 were contacted with synthetic solution and the remaining six cells were contacted with tailings solution. The synthetic solution contains the major constituents of the tailing solution, but is free of radioactivity (see Table 4.6).

The method used for determining permeability was the ASTM Method for determining constant head permeability, with some minor modificiations (ASTM 
TABLE 4.6. Macroconstituents of Tailings Solution

\begin{tabular}{lcc}
\multicolumn{2}{c}{$\begin{array}{c}\text { Tailings } \\
\text { Solution }(\mathrm{mg} / 1)\end{array}$} & $\begin{array}{c}\text { Synthetic } \\
\text { Solution }(\mathrm{mg} / 1)\end{array}$ \\
\cline { 1 - 2 } $\mathrm{pH}$ & 2.0 units & 2.0 units \\
$\mathrm{Al}^{3+}$ & 578 & 580 \\
$\mathrm{Ca}^{2+}$ & 484 & 480 \\
$\mathrm{Fe}^{2+}$ & 2,200 & 2,200 \\
$\mathrm{Mg}^{2+}$ & 650 & 650 \\
$\mathrm{Na}^{2+}$ & 330 & 330 \\
$\mathrm{Si}^{2+}$ & 233 & 0 \\
$\mathrm{Cl}^{-}$ & 97 & 100 \\
$\mathrm{NO}_{3}^{-}$ & 16 & 15 \\
$\mathrm{SO}_{4}{ }^{2-}$ & 12,850 & 13,000
\end{tabular}

1978). The flow through the cells was from bottom to the top to ensure saturated flow conditions. Figure 4.9 shows a block diagram of the saturated flow apparatus used for all of the samples. Figure 4.10 shows three permeameter cells connected to the pressure system and to outflow collection cylinders.

The permeability $(K)$ is calculated by multiplying the flow rate in $\mathrm{ml} /$ day by a cell constant. The cell constant is the length of the cell (L) divided by the cross-sectional area times the hydraulic head.

$$
\text { Cel1 Constant }=\frac{L(c m)}{A(c m)^{2} H(c m)} \times \frac{1}{\text { sec/day }} \frac{1}{86400}
$$

The permeability was computed by multipiying measured daily flow volumes by the cell constant.

$$
K(\mathrm{~cm} / \mathrm{s})=\frac{Q(\mathrm{~cm})^{3}}{\text { T(days })} \times \frac{L(\mathrm{~cm})}{A(\mathrm{~cm})^{2} \mathrm{H}(\mathrm{cm}) 86400 \mathrm{~s} / \text { day }}=\text { Flow Rate } \times \text { Cell Constant }
$$




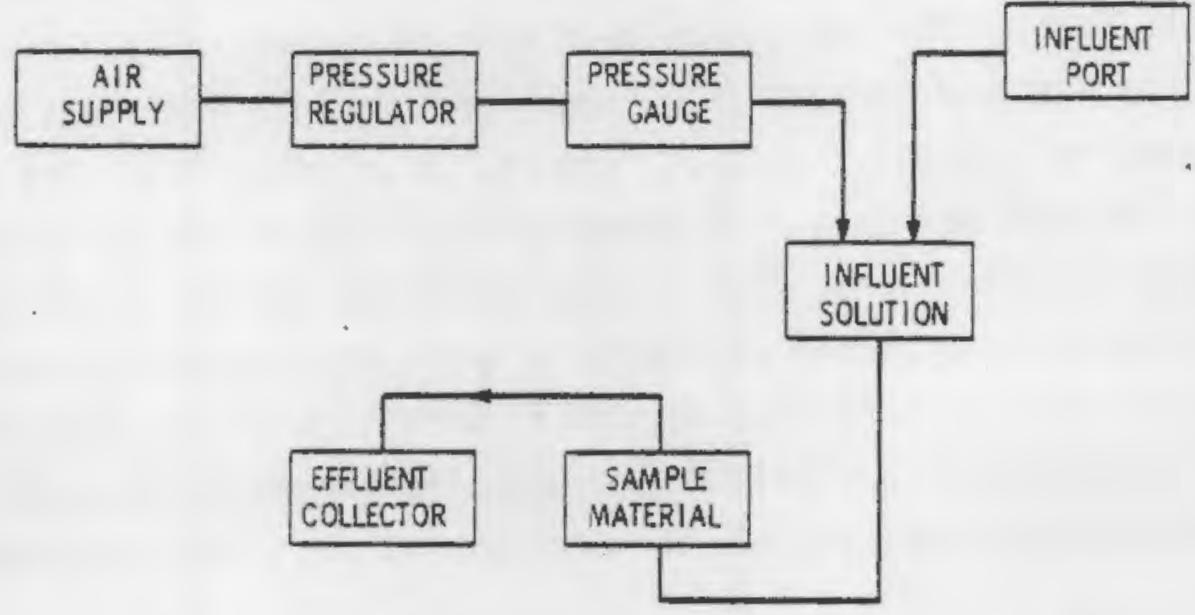

FIGURE 4.9. Pressurized Flow System for Determining Constant Head Permeability

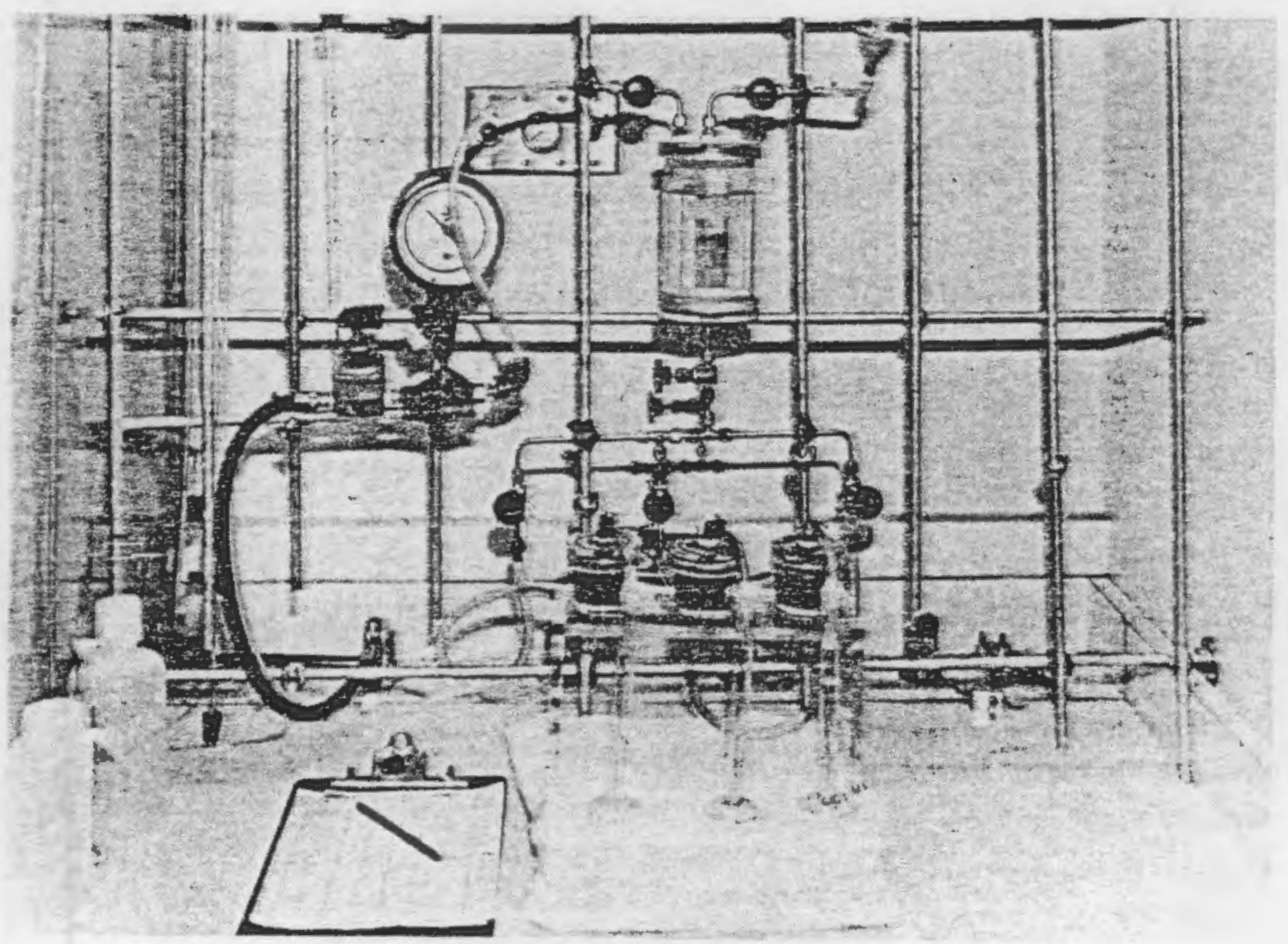

FIGURE 4.10. Pressurized Permeameter Setup for Measuring Permeability of Clay Liner Materials 
The cells packed with the clay liner material were pressurized to accelerate the flow through the test materials. This technique was tried initially on the synthetic solution-clay liner samples. This enabled us to simulate long-term effects in a shorter time period. For cell 1, the pressure was increased at three different points over time to determine if there was any effect on the measured permeability (see Figure 4.11). There was no measurable influence of hydraulic head differences on permeability. The hydrualic head has since been maintained at approximately $1460 \mathrm{~cm}$ for all clay samples. To determine the effect that flow through fractures has on the permeability, material in cell 2 was packed initially in a slightly undersized cell and then transferred to cell 2. After 50 days of flow through cell 2, the surface of the clay liner material was recompacted with the tamper to see what the change in permeability would be, and if recompaction had any effect on chemical migration.

\section{Results of Permeability Tests}

The permeabilities of the Morton Ranch clay liner material varied from $5 \times 10^{-8} \mathrm{~cm} / \mathrm{s}$ to $1.5 \times 10^{-10} \mathrm{~cm} / \mathrm{s}$. The apparent reason for such a wide range of permeabilities can be attributed to packing differences of the clay material. The average permeability for all the clay sample cells is $7.5 \times 10^{-9} \mathrm{~cm} / \mathrm{s}$. The change in permeability has been very small for the samples with initial permeabilities of less than $1 \times 10^{-8} \mathrm{~cm} / \mathrm{s}$. The scatter in the data for ce 114 is due to the inability to accurately measure a flow rate of $0.1 \mathrm{ml} /$ day or less.

On all but two of the clay liner samples, we noted an initial rapid decrease in permeability. For cell 2 (which was recompacted in place after 50 days of solution contact), the permeability dropped by an order of magnitude after recompaction (Figure 4.11). For the clay liner material after the initial 50 days, all tests have shown either near steady flow or slow decreases in flow rates with time. Some samples have been under solution contact for 8 months, and outflows from the most permeable columns have exceeded 10 pore volumes. The data suggest that physical manipulation (compaction) has a rather dramatic effect on permeability, and that physical mechanisms which 


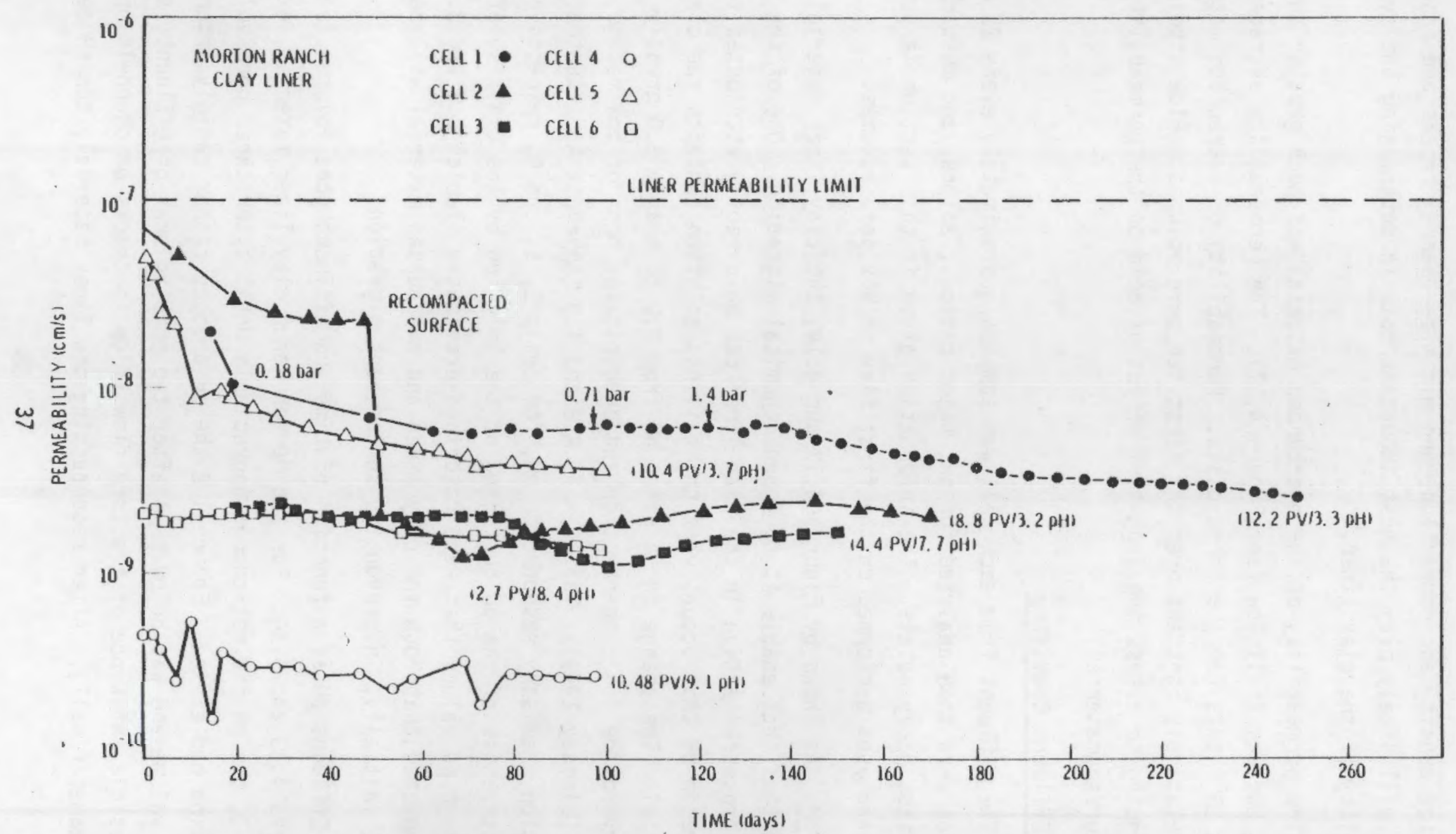

FIGURE 4.11. Permeability of Morton Ranch Clay Liner Material as a Function of Time (Efflluent pore volumes and $\mathrm{pH}$ are indicated for the last data point for each cell.) 
optimize density and compaction, and minimize channel cracks and fracture flow, will likely play the most important role in determining the overall permeability of the clay liner.

The permeability of the overburden material was much greater than the clay, but was still low (see Figure 4.12). The permeability averaged $3.7 \times 10^{-7} \mathrm{~cm} / \mathrm{s}$ for the three cells. Permeability of overburden material was relatively constant over the first ten pore volumes. Flow studies are continuing to assess the long-term effect of acid on the permeability of the overburden material.

\section{Effluent Chemistry}

The effluent from each cell was sampled approximately every $20 \mathrm{ml}$. These samples were then analyzed for $\mathrm{pH}$, major cations, anions, and most of the important heavy metals. The information given in this section is primarily from analyses performed on the first five to six pore volumes.

pH. As shown by Figures 4.13 and 4.14 , the clay liner material does have properties that enable it to impede chemical migration. One of the attenuation processes active in the clay liner can be directly attributed to the change in $\mathrm{pH}$ that occurs when the tailings solution contacts the clay liner material. The change in solution $\mathrm{pH}$ from 2.0 to nearly 8.0 greatly increases the hydroxide ion concentration and precipitates most of the metals as hydroxides (Lindsay 1979). Tables A.7, A.8 and A.9 (Appendix A) illustrate the solution chemistry response to $\mathrm{pH}$, for cells 1,5 , and 8 , respectively. The effectiveness of the $\mathrm{pH}$ buffering of the solution by the clay is reflected in the high Kd values that were described previously (Tables 3.2 and 3.3 ) and it is expected that both the clay liner and overburden material will be effective, initially, in preventing contaminant migration.

Effluent $\mathrm{pH}$ as a function of time and effluent pore volumes is shown in Figures 4.13 and 4.14. For the Morton Ranch clay liner material, except for cell 2, the pH did not change appreciably until after three pore volumes of solution had eluted. For cell 2 the $\mathrm{pH}$ dropped rather rapidly after the first pore volume and was below pH 4 after two pore volumes of effluent, suggesting a possible influence of fracture flow (flow in cracks or channels or along the permeameter wall). After recompacting the liner material, the pH decreased 


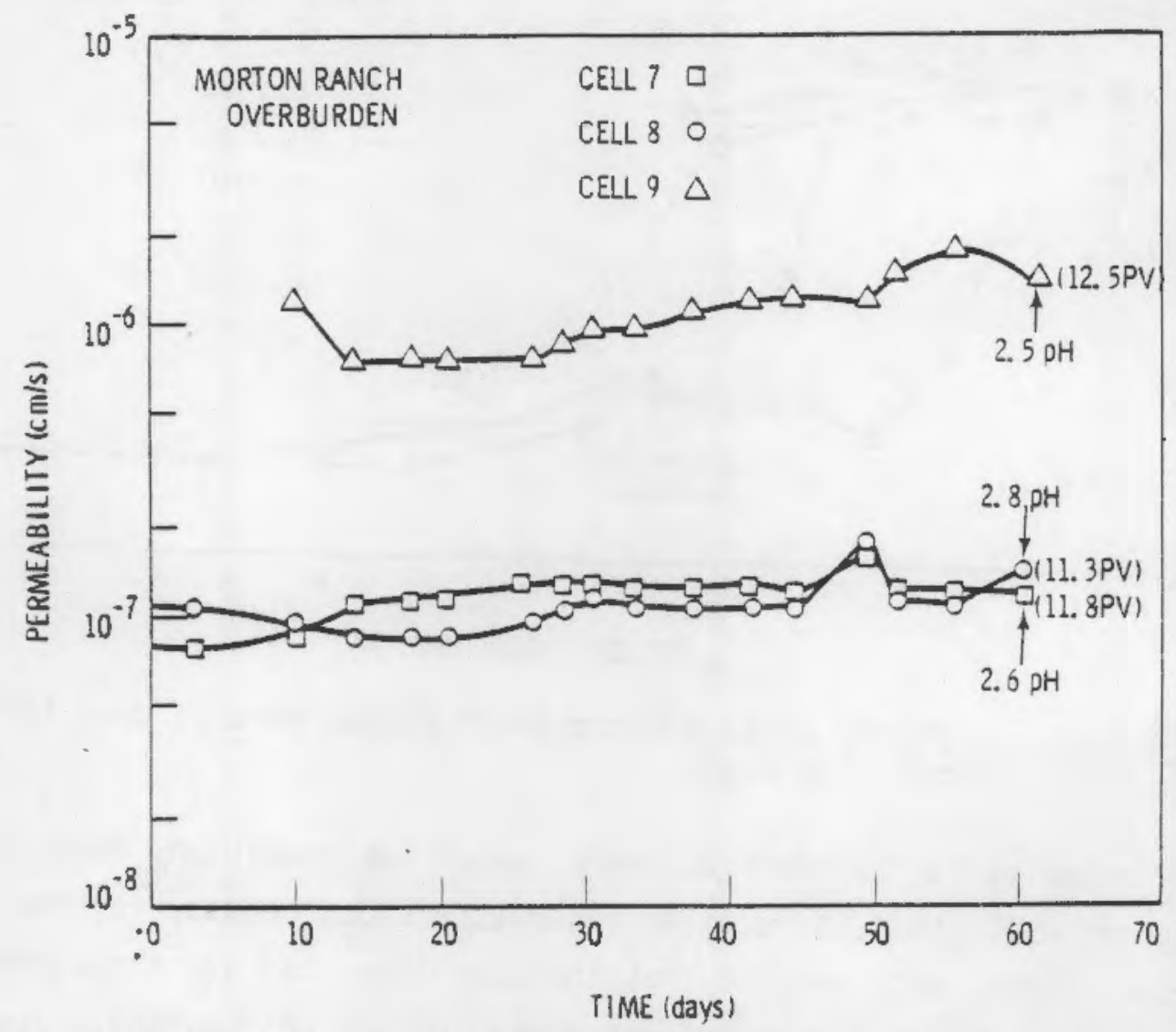

FIGURE 4.12. Permeability of Morton Ranch Overburden as a Function of Time (Effluent pore volumes and $\mathrm{pH}$ are indicated for the last data point for each cel1.)

slowly and in a manner similar to the other clay liner materials. None of the clay liner samples dropped in $\mathrm{pH}$ below three during the testing period. The data suggest that if the clay liner is adequately compacted and no fracture flow occurs, the pH will remain above 4 for rather long periods of time. For a compacted clay liner $1 \mathrm{~m}$ thick, with a permeability of $10^{-8} \mathrm{~cm} / \mathrm{s}$, the maximum flow through the liner would be less than 2 pore volumes in 20 years, if we assume a constant pressure head gradient of 10 . This size of head gradient might exist in an evaporation pond that was constantly filled to a depth of at least $9 \mathrm{~m}(30 \mathrm{ft}$ ), but would be conservatively high (by a factor of 5 to 10) for any pit tailings disposal alternatives (Nelson et al. 1980). From Figures 4.11 and 4.13 , the clay liner material can be shown to have adequate buffer capacity and sufficiently low permeability to neutralize all 


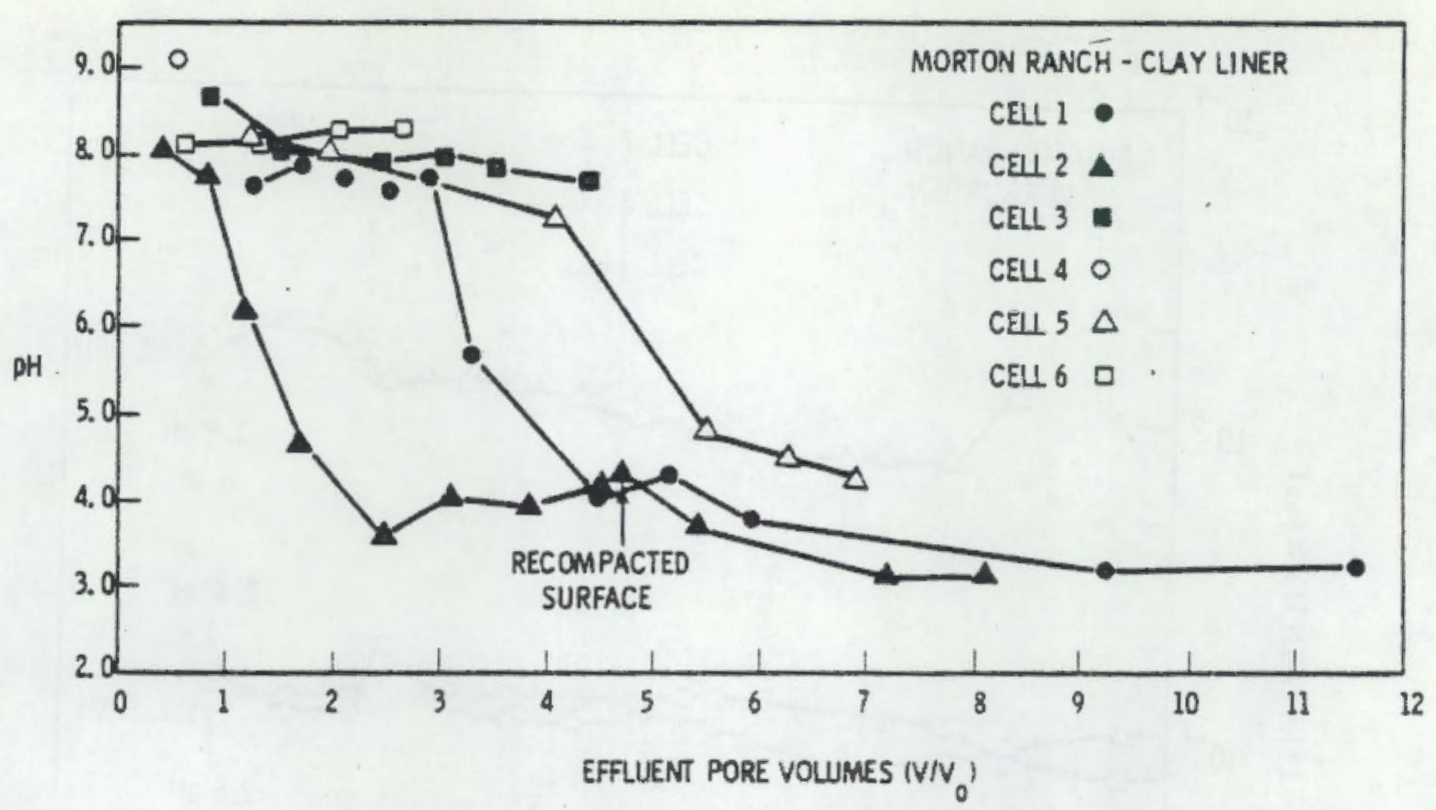

FIGURE 4.13. Effluent pH as a Function of Eluted Pore Volumes for Morton Ranch Clay Liner

effluent solution for at least 20 years, under the conditions described above. From Figures 4.12 and 4.14, similar observations can be made for the compacted overburden. These data suggest that the clay liner and overburden materials will provide a barrier to contaminant migration not only by their low permeability but also by their buffer capacity (see also Nelson et al. 1980). Longterm effects of $10 \mathrm{w} \mathrm{pH}$ on chemical transport through liner and overburden materials are not well documented and should be the subject of additional research. The following data illustrate the initial effects of acid leaching of clay liner materials.

Sulfate. Chemical reactions occurred in the clay liner to markedly reduce the sulfate concentration of the column effluent substantially below the concentration of the influent. Figure 4.15 shows sulfate breakthrough curves for Morton Ranch clay liner material (cells 1 and 2). and illustrates the response of the sulfate concentration with increasing effluent pore volumes. Additional data on sulfate response are presented in Appendix A (Tables A.7, A.8 and A.9). These data indicate that sulfate is reacting with the clay liner material and that for well compacted samples, the effiuent is 


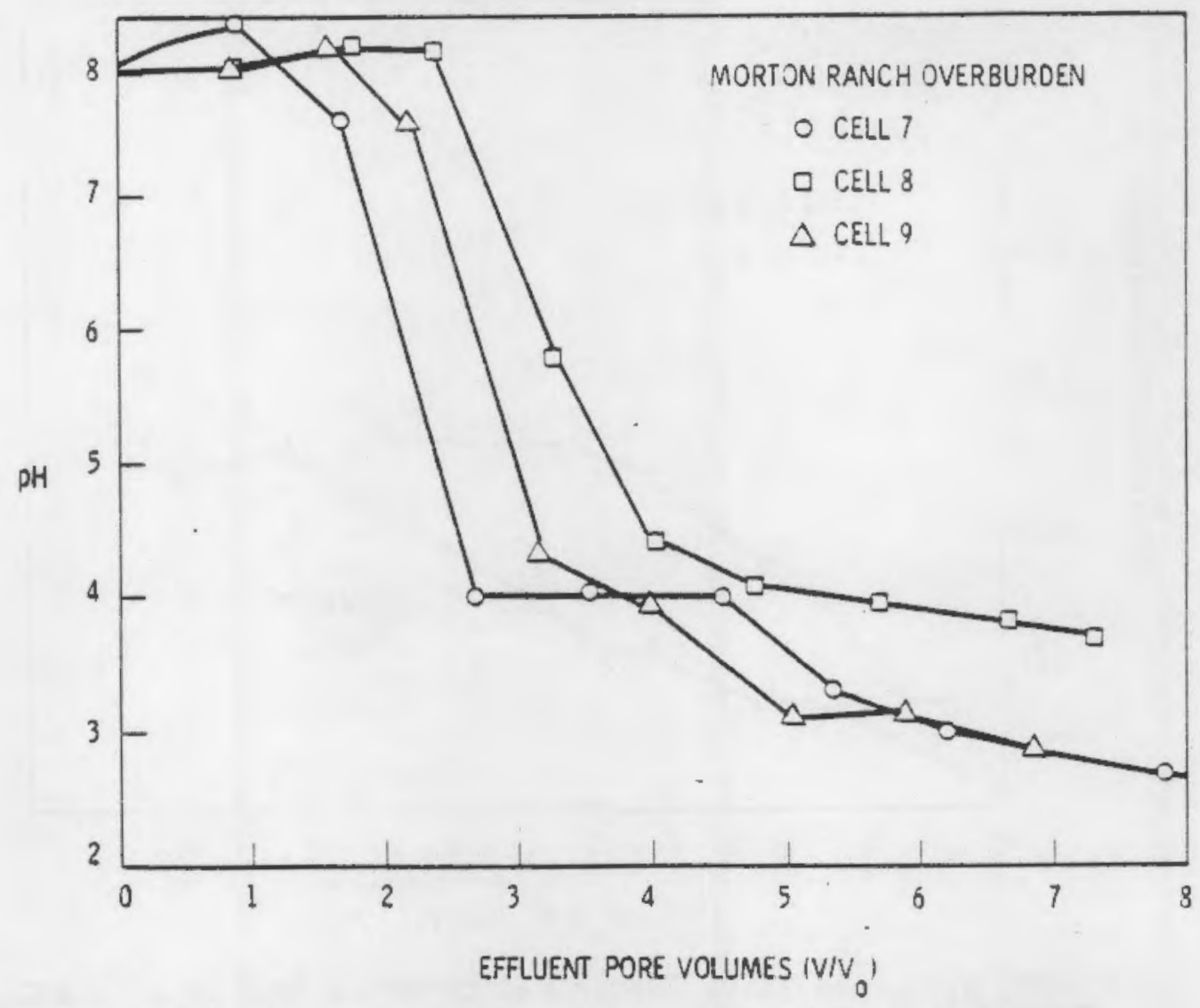

FIGURE 4.14. Eff1uent $\mathrm{pH}$ as a Function of Pore Volumes Eluted from Morton Ranch Overburden

substantially less concentrated than the influent, particularly for the first 3 or 4 pore volumes. The previous section's analys is of seepage rates through a 1-m thick clay liner for a 20-year period suggests that the sulfate concentration potentially reaching the ground water would never be more than about $2600 \mathrm{mg} / 1$ for a tailings solution whose initial concentration is $13,000 \mathrm{mg} / 1$. These results suggest that the model analys is of contaminant transport by Nelson et al. 1980 is highly conservative since they considered the sulfate to be water coincident, i.e., with no chemical reactions taking place. The exact nature of the chemical reaction between the clay and the sulfate has not been thoroughly investigated, but the next sections on aluminum and iron suggest possible ways that sulfate is interacting with the clay liner material. 


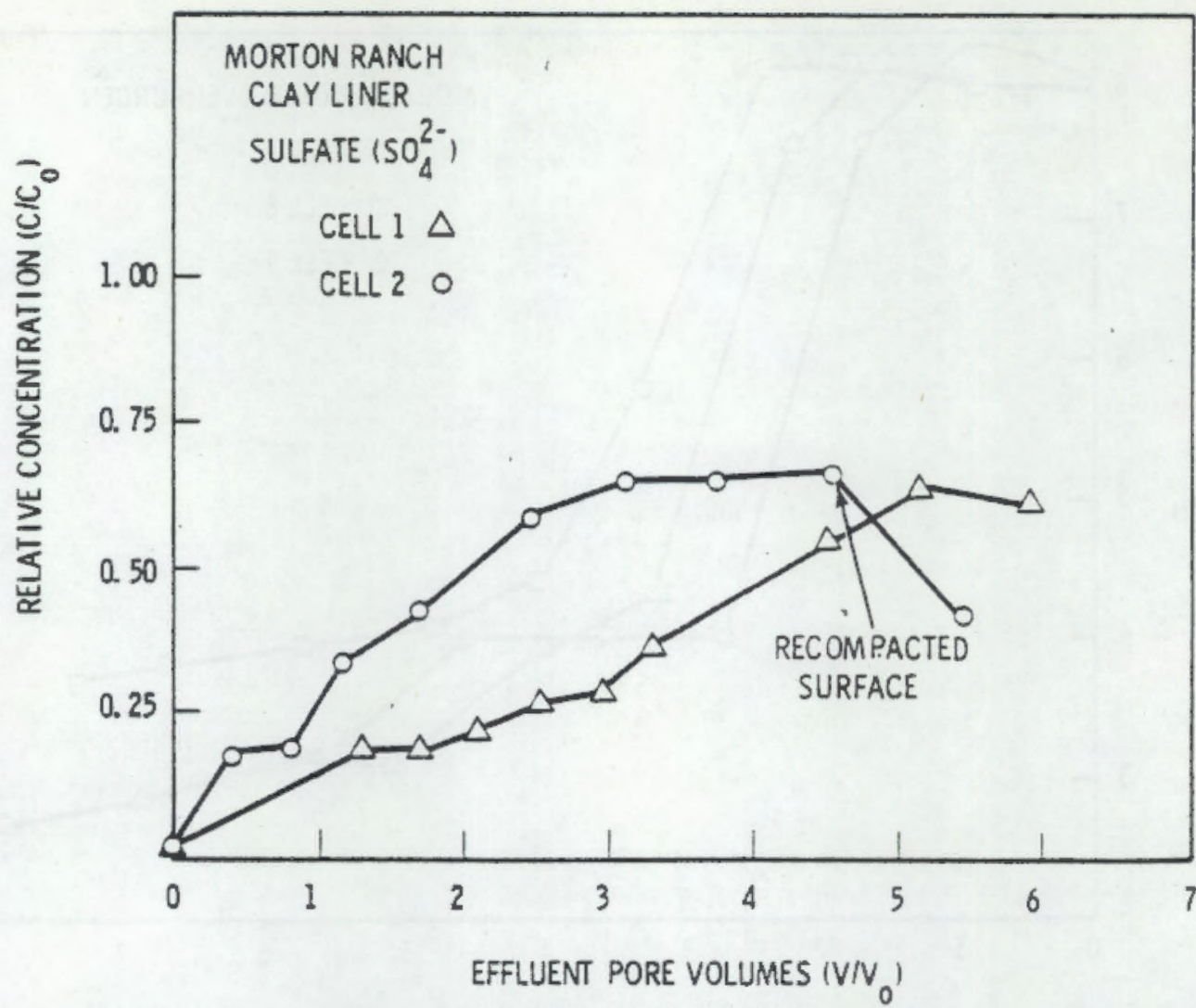

FIGURE 4.15. Relative Concentration of Sulfate in Effluent from Morton Ranch Clay Liner as a Function of Effluent Pore Volumes

Aluminum. Figure 4.16 shows the aluminum and iron concentrations in the effluent from Morton Ranch clay liner samples after prolonged leaching with tailings solution. The solubility of the iron and aluminum (and hence, the effluent concentration of these species) is controlled by the chemical and mineral equilibrium that exists within the solution when it comes in contact with the clay liner material. In the case of aluminum, numerous equilbria govern its solubility. Several aluminum oxides, hydroxides, and complex aluminosilicates exist in soils. In the test flow system, the aluminum concentration is dependent on amorphous forms of all these aluminum compounds. From the species that are present in the effluent solution, it would appear that as the acid front begins to move through the clay material, silicon is dissolved from 


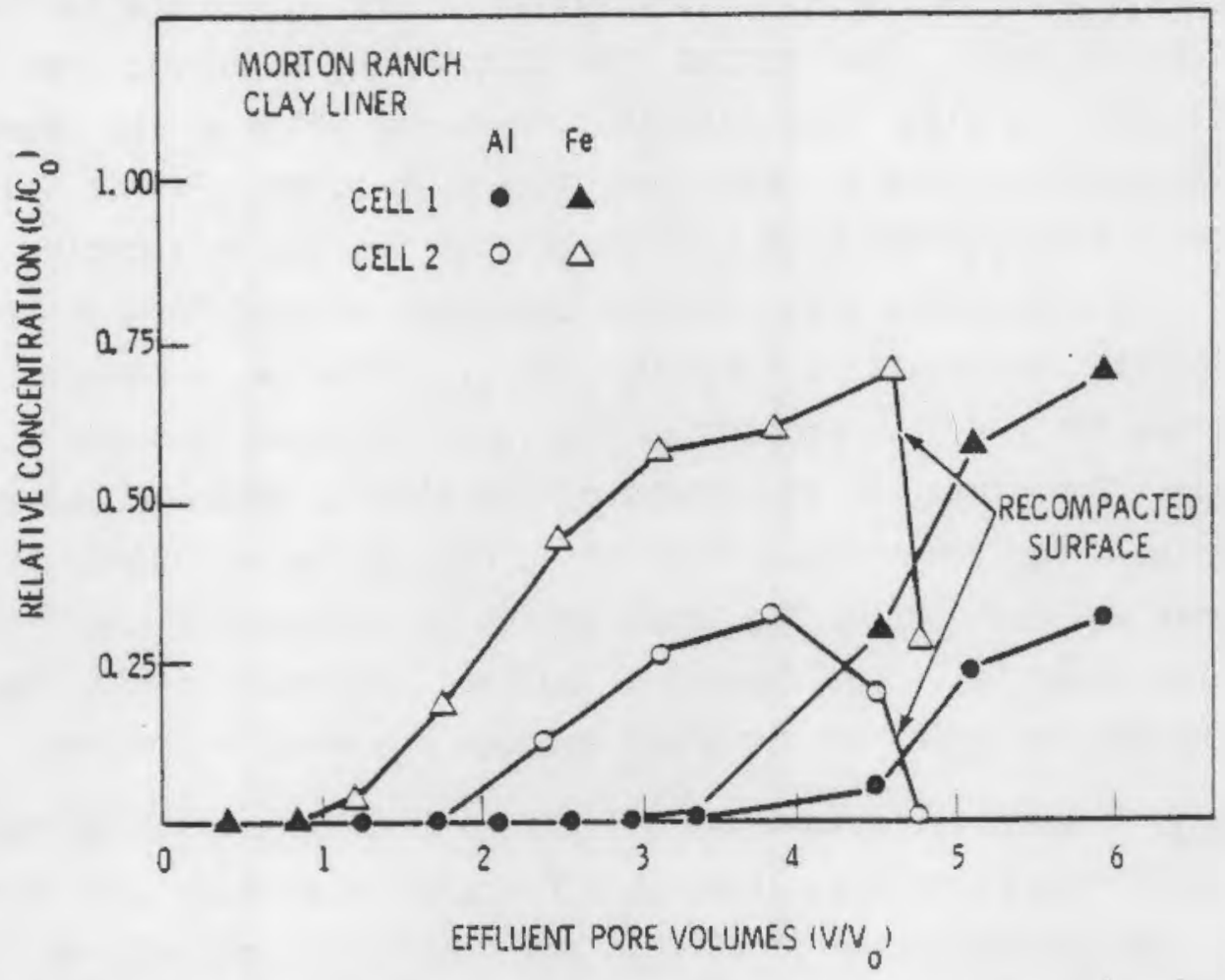

FIGURE 4.16. Relative Concentration of $\mathrm{Al}$ and $\mathrm{Fe}$ in Effluent from Morton Ranch Clay Liner as a Function of Effluent Pore Volumes

the clay and combined with the silicon already present in the tailings solution, and aluminosilicates begin to precipitate. The important point to consider is the fact that the major portion of the aluminum, silicon, and other elements which form amorphous mineral precipitates are supplied by the tailings solution. This decreases the weathering power of the tailing solution, because it must first redissolve the less stable amorphous solids before attacking the more stable crystalline forms of the soil (Lindsay 1979). Weathering of the crystalline forms will still take place in that portion of the $\mathrm{clay}$ material that is approaching the influent $\mathrm{pH}(2$ to-3). As dissolution of primary clay minerals continues, a group of more stable secondary forms begins precipitating. Secondary mineral formation has been documented by several authors (Breeman 1976, Rhodes and Lindsey 1978, 801t and 8ruggenwert 1978). Conditions required for this process to occur have been found in nature and are characterized by high sulfate concentration, soluble aluminum or iron, and a $\mathrm{pH}$ of below 4. At $\mathrm{pH}^{\prime} \mathrm{s}$ below 4, an amorphous mineral form of alunite $\mathrm{KAl}_{3}\left(\mathrm{SO}_{4}\right)_{2}(\mathrm{OH})_{6}$ - which is less soluble than gibbsite - $\mathrm{Al}(\mathrm{OH})_{3}$ - is the primary solid phase. 
Iron. The iron in the tailings solution is present in the ferrous $\left(\mathrm{Fe}^{2+}\right)$ oxidation state. The ferrous iron is oxidized to ferric iron $\left(\mathrm{Fe}^{3+}\right)$ after contacting the clay liner material. This was noted by the change in color of the solution from a light green to a rust color. Ferric hydroxide precipitate - $\mathrm{Fe}(\mathrm{OH})_{3}$ /amorphous - forms at high pHs and only begins to redissolve as the $\mathrm{pH}$ approaches 4.0. Another amorphous mineral form of iron that will precipitate is jarosite $-\mathrm{KFe}_{3}\left(\mathrm{SO}_{4}\right)_{2}(\mathrm{OH})_{6}$. Jarosite, a member of the alunite group, has chemical properties that are analogous to those of alunite for aluminum. The formation of members of the alunite group is common in acid sulfate soils. From the concentration of sulfate in the effluent, it is apparent that at least $50 \%$ of the total amount of sulf ate has been removed by the clay liner material. The removal of sulfate continues even at low pHs, which reinforces the case for amorphous secondary mineral formation.

Silicon. Figure 4.17 shows the silicon (Si) concentration in the effluent from the Morton Ranch Clay liner as a function of pore volumes of effluent. The initial low. concentration of silicon and subsequent increase with decreasing $\mathrm{pH}$ suggests that some solubility of the Si occurs as $\mathrm{pH}$ decreases, in keeping with concepts of mineral solubility (Lindsay 1979) for solutions of low concentration in contact with silicate minerals. However, Table A.8 indicates that when the solution has a high initial concentration of $\mathrm{Si}$, as does the tailings solution, that the subsequent concentration of $\mathrm{Si}$ is well below the initial concentration (by a factor of 9 to 10 ) even after extensive leaching ( 8 pore volumes), which suggests that $S i$ is being precipitated or that it is reacting chemically with the clay minerals.

The scope of this section has been to determine to what extent the tailings solution has dissolved the clay liner material and whether the clay liner is a good barrier to chemical migration. Several conditions that are important to determining when the clay liner material has been chemically breached, can be sumarized as follows.

1) Significant $\mathrm{pH}$ changes. The primary dependence of effluent chemical composition is on $\mathrm{pH}$. Heavy metal and radionuclide effluent concentrations do not change until the buffering capacity is overcome and the $\mathrm{pH}$ of the effluent drops. 


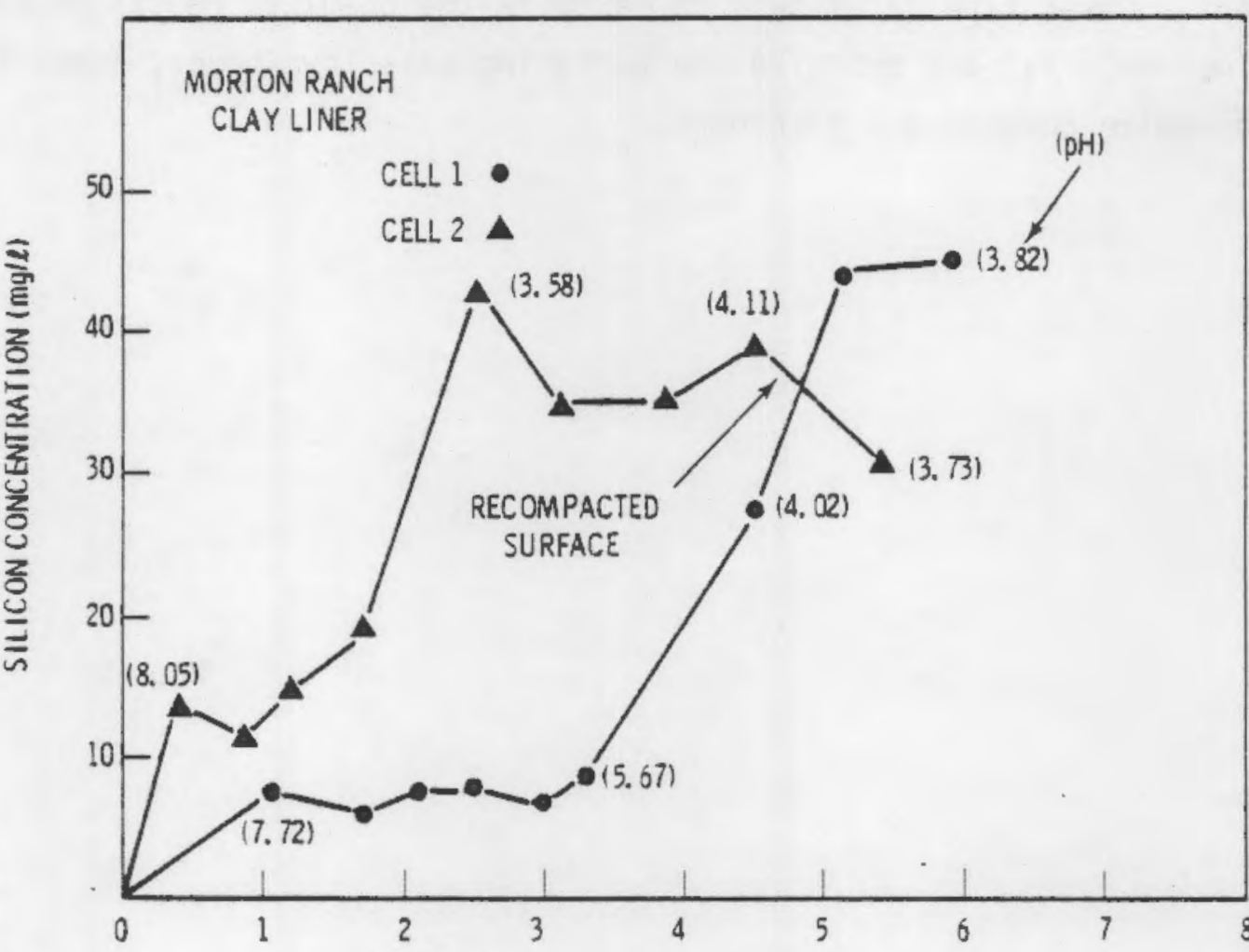

EFFLUENT PORE VOLUMES IV/No'

FIGURE 4.17. Relative Concentration of Sulfate in Effluent from Morton Ranch Clay Liner as a Function of Effluent Pore Volumes

2) Increased sulfate concentrations. Sulfate concentrations of effluent increase somewhat more rapidly than $\mathrm{pH}$ but are always less than influent values.

3) Increased iron and aluminum concentrations. In low-permeability media, the iron and aluminum breakthrough is severely retarded, because these species will precipitate as hydroxides and as amorphous members of the alunite mineral group. The dependence of these reactions on flow can be illustrated by the dramatic drop in iron and aluminum concentrations after recompation of cell 2 (see Figure 4. 16). These precipitates tend to decrease permeability. 
In sumary, we can say that the permeability has not yet been adversely affected by the tailings solution. In addition, with a decrease in permeability, the clay liner material will have an increased ability to impede chemical transport. Lower flow rates tend to maximize the chemical reactions with the clay liner material and optimize the buffering capacity; hence, lower flow rates minimize contaminant transport. 


\section{RECOMMENOATIONS}

Based on the laboratory test results, several general recomendations can be made regarding mill tailings management at Morton Ranch.

1. No disposal of untreated tailings that would allow ground water to come into direct contact with the tailings should be permitted. Acid leachate of low pH (below 3) contains heavy metals and radionuclides in concentrations exceeding MPC values.

2. Neutralization of the tailings will provide optimum control for iong-term protection against ground water contamination by leachate. However, for drained tailings in clay lined pits, leachate losses should be minimal. because compacted clay liner permeabilities are very low.

3. Chemical analysis for heavy metals in tailings solution and seepage water from tailings pits or ponds should be run against standards that correct for matrix interference by sulfate and total dissolved solids. ICP analysis is not recamended for uranium or thorium. Radiochemical data from properly calibrated intrinsic germanium diodes should provide the most direct way to analyze for uranium and the most important uranium daughter products found in mitl tallings and mill tailings solution.

4. On-site clay and siltstone materials to be used for clay iiners should be tested to assure that EPA liner requirenents are met, particularly regarding texture and clay percentages. In addition, 90\% or greater compaction is recommended to assure that minimum permeability is achieved. 


\section{REFERENCES}

ASTM. 1978. Annual Book of ASTM Standards Part 19. American Society for Testing and Materials, Philadelphia.

A.P.H.A. 1975, Standard Methods for the Examination of Water and Waste Waters. 14th Edition, APHA. Wasnington, D.C.

Barrow, N. J., and T. C. Shaw. 1979. "Effects of Solution:Soil Ratio and Vigour of Shaking on the Rate of Phosphate Adsorption by Soil." J. Soil Sci. $30: 67-76$.

81ack, C. A. 1965. Methods of Soil Analysis. Part 1. Physical and Minerological Properties including Statistics of Measurement and Sampling. Anerican Societ of Agronomy Monograph 9 .

Boit, G. H. and M. G. M. Brugenwert. 1978. Soil Chemistry. A. Basic Elements, p. 166. Elsevier Scientific Publishing Company, Amsterdam, The Nether lands.

Breeman, N. van. 1976. "Genesis and Solution Chemistry of Acid Sulfate Soils in Thailand." Agric. Res. Rep. (Vers 1. landbouwk Onder 2.) 848. Wegen ingen, The NetherTands.

Brown, K. W. and D. Anderson. 1980. "Effect of Organic Chenicals on Clay Liner Permeability." In Proceedings of the Sixth Annual Research Symposium on Disposal of Hazardous Waste, Chicago, Minois.

Davis, S. N. and R. J. Dewiest. 1966. Hydrogeology. John Wiley and Sons. New York. $463 \mathrm{p}$.

Erotmann, G. and W. Soyka. 1975. "The Gama-ray of Radionuclides, Ordered by Atomic and Mass Number." U. Radioanalytical Chem. 27:137-286.

Gee, G. W., A. Bauer, and R. S. Decker. 1978. "Physical Analyses of Overburden Materiais and Mined Land Soils." Amer. Soc. of Agron. 38:665-686, In F. W. Schaller and P. Sutton (eds.) Reclamation of Drastically oisturbed Lands. Madison, Wisconsin.

Kimber ley, M. M. 1978. Uranium Deposits, Their Minerology and Origin. Short course by the Minerohogical Assoctation of Canada, Volume 3.

Lindsay, Will ard L. 1979. Chemical Equilibria in Soils. p. 35,129, John Wiley and Sons. New York, New York.

Nelson, R. W., A. E. Reisenaver and G. W. Gee. 1980. Model Assessment of Alternatives for Reducing Seepage of Contaminants from Buried Uranium Mill lailings at the Morton Ranch Site in Central Wyoming. PNL-3378, Pacific Northwest Laboratory, Richiand, Washington. *ᄎ 
Quinby-tiunt, M. S. 1978. "A Survey of Instruments Used for Monitoring Metals in Water." Amer. Lab. 10(13):17-37.

Rhodes, E. R. and W. L. Lindsay, 1978. "Solubility of Aluminum in Some Soi?s of the Humid Tropics." J. SoiT Sci. 29:324-330.

Re isenauer, A. E. 1973. Caiculation of Soil Hydraulic Conductivity from Soil Water Retention Relationshios. BNWL-1710, Pacific Northwest Laboratory.

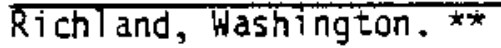

Sherard, J. L., L. P. Dunningan, and R. S. Decker. 1976, "Identification and Nature of Dispersive Soils." Am. Soc. Civil Engr. J. Geo-tech. Eng. Div. 101 (GT4).

U.S. Environmental Protection Agency. 1978. Hazardous Waste. Proposed Guidelines and Regulations and Proposal on Identification and Listing. Federa I Register, $43(243): 58946-59026$.

U.S. Enviromentai Protection Agency. 1979. "Selenium, Method 270.3, Gaseous Hydride." In Methods for Chenical Analys is of Water and Wastewater. EPA-600/4-79-020. U.S. EPA, Cineinnati, ohio.

U.S. Nuclear Regulatory Commission. 1979a. Final Environmental Statement: Morton Ranch Wyoming Uranium Mill, United Nuclear Corporation. NUREG 0532. Washington, D.C. *

U.S. Nuclear Regulatory Commission, 1979b. Braft Generic Environmentai Impact Statement on Uranium Mitiing. NUREG 0511, Nasnington, D.C. *t*

Ward, A. F., H. R. Sobel and R. L. Crawford. 1976. "The Preservation of Accuracy in the Determination of Trace Elements in Complex Matrices Using Inductively Coupled Argon Plasma Optical Emission Spectroscopy." Paper presented at the 3rd Annual FACSS Meeting, November, 1976. Philadelphia.

* Available for purchase from the NRC/GPO Sales Program, U.S. Nuclear Regulatory Commission, Washington, D.C. 20555, and the National Technical Information Service, Springfield, VA 22161

**Available for Durchase from the National Technical Information Service, Springfield, VA 22161.

***Available free upon written request to the Division of Technical Information and Document Control. U.S. Nuclear Regulatory Commission, Washinaton, D.C. 20555 

APPENDIX A

ICP ANALYSIS OF THE URANIUM MILL TAILINGS SOLUTIONS 
APPENDIX A

\section{ICP ANALYSIS OF THE URANIUM MILL TAILINGS SOLUTIONS}

Knowledge of the chemical maxe-up of the tailings solution was necessary for understanding its interactions with pit liner materials. An increasingly common technique for multielement analysis was used for our study: inductively coupled argon plasma emission spectroscopy (ICP). For a wide range of samples analyzed by $I C P$, there are virtually no chemical interferences. The extremely high temperatures achieved with the plasma completely break down compounds and discourage the formation of new ones. Also, most element concentrations are linear for a range of greater than 100,000 units. This permits analys is of samples with extremes in element concentrations. Detection limits are aiso very low for many elements. The concentration that gives a signal equal to twice the standard deviation of the background is defined as the detection limit. Table A.1 lists the range of detection limits for water that have been reported from different sources.

TABLE A.I. Detection Limits for Water Reported by Several Manufacturers of Inductively Coupled Argon Plasma Emission Spectrometers (in $j g / 1)(a)$

\begin{tabular}{|c|c|c|c|}
\hline Element & Detection Limit & Element & Detection Limit \\
\hline $\begin{array}{l}\mathrm{Ag} \\
\mathrm{AI} \\
\mathrm{As} \\
\mathrm{Ba} \\
\mathrm{Ca} \\
\mathrm{Cd} \\
\mathrm{Ca} \\
\mathrm{Cr} \\
\mathrm{Cu} \\
\mathrm{Fe} \\
\mathrm{Mg} \\
\mathrm{Mn}\end{array}$ & $\begin{array}{c}4-15 \\
7-15 \\
20-330 \\
0.2-5 \\
0.9-4 \\
1-5 \\
2-5 \\
2-6 \\
1-2 \\
0.5-3 \\
0.5-50 \\
0.2-0.5\end{array}$ & $\begin{array}{l}\text { Mo } \\
\mathrm{Na} \\
\mathrm{Ni} \\
\mathrm{P} \\
\mathrm{Pb} \\
\mathrm{Se} \\
\mathrm{Si} \\
\mathrm{Sn} \\
\mathrm{Th} \\
\mathrm{U} \\
\mathrm{Zn} \\
\mathrm{Zr}\end{array}$ & $\begin{array}{c}5-22 \\
1-75 \\
6-19 \\
30 \\
20-50 \\
20-93 \\
10 \\
6-70 \\
75-100 r \\
75 \\
2-10 \\
2-5\end{array}$ \\
\hline
\end{tabular}

(a) Taken from Quinby-Hunt (1978) 
MATERIALS AND METHODS

The samples were analyzed using a Jarrel1-Ash Plasma AtomComp DirectReading Spectrometer with its inductively coupled argon plasma source. The atomized sample is carried on a stream of argon gas into the argon plasma. Elements are thermaliy excited and they emit light which is collimated and directed onto a grating surface. The diffracted light is converted to electrical energy proportional to the light's intensity by photomultiplier tubes. A computer then converts the signals to concentration units and outputs the information.

\section{Standards}

The high excitation temperatures of ICP reduce the need for careful sample standard matrix matching. Standards, prepared from Spex certified standards, were periodically analyzed to monitor machine calibration. These standards were originally formulated for use in analyzing geothemal samples, which typically are acidic and have a wide complement of heavy metals. The chemical composition of the standards used and their ICP detection limits are listed in Table A.2. Table A.3 contains ICP computer printout data for two of. the standards. Values, in $\mathrm{mg} / 1$, are reported for more elements than were actualiy added for the standard. Detection limits were established based on these spectrai interferences.

For samples with concentrations greater than the standards, dilution was required before anaiysis. Distilled, deionized water was used to make the five-, ten-, or one hundred-fold ditutions. Whenever a sample was diluted to bring it within the range of the standards, the detection limits had to be adjusted accordingly; i.e., a ten-fold dilution statistically corresponded with a ten-fold increase in detection limit. This explains the different detection timits reported for an element for two different solutions. 
TABLE A.2. Standard Composition and Detection Limit for ICP Analysis (mg/1)

\begin{tabular}{|c|c|c|}
\hline Parameter & Concentration in Standards & Detection Limit \\
\hline$A g$ & 10 & 0.04 \\
\hline Al & 10 & 0.1 \\
\hline As & 10 & 0.1 \\
\hline $\mathrm{Ca}$ & 50 & 0.1 \\
\hline $\operatorname{cod}$ & 10 & 0.01 \\
\hline $\mathrm{Cr}$ & 10 & 0.01 \\
\hline $\mathrm{Cu}$ & 10 & 0.1 \\
\hline $\mathrm{Fe}$ & 10 & 0.1 \\
\hline L & 10 & 0.05 \\
\hline$M g$ & 10 & 0.05 \\
\hline$M_{n}$ & 10 & 0.01 \\
\hline Mo & 10 & 0.1 \\
\hline $\mathrm{Na}$ & 500 & 5.0 \\
\hline $\mathrm{Ni}$ & 10 & 0.08 \\
\hline$P$ & 10 & 0.5 \\
\hline $\mathrm{Pb}$ & 10 & 0.1 \\
\hline $\mathrm{Se}$ & $\cdot$ & 0.1 \\
\hline Si & 100 & 0.1 \\
\hline $\mathrm{Sr}$ & 10 & 0.01 \\
\hline Th & 10 & 0.1 \\
\hline $\mathrm{U}$ & 10 & 0.05 \\
\hline $2 n$ & 10 & 0.05 \\
\hline $\mathrm{Zr}$ & 10 & 0.05 \\
\hline
\end{tabular}


TABLE A.3. ICP Data for Two Standards Showing Matrix Interferences

(i) 5 TI 3

EHGCGHAC

\begin{tabular}{|c|c|c|c|c|c|c|c|c|c|}
\hline $\begin{array}{r}\text { EUKN }=t \\
16>0\end{array}$ & GEOT & & $6: 27$ & DANAO & & & & & \\
\hline 9.999 & .0000 & 10.11 & .2403 & 10.1 .7 & 23.2 & 9.790 & .1126 & 503 & .2130 \\
\hline $\begin{array}{l}.31 .63 \\
.0173 \\
9.509\end{array}$ & $\begin{array}{r}10.17 \\
.1339 \\
\because \quad 0\end{array}$ & $\begin{array}{l}.0061 \\
10.14\end{array}$ & $\begin{array}{r}0 \\
.6517\end{array}$ & $\begin{array}{l}.0040 \\
10.01\end{array}$ & $\begin{array}{r}.0124 \\
.4334\end{array}$ & $\therefore 0$ & $\begin{array}{l}10.07 \\
.3725\end{array}$ & $\begin{array}{l}10.23 \\
9.924\end{array}$ & $\therefore$ \\
\hline
\end{tabular}

\begin{tabular}{|c|c|c|c|c|c|c|c|c|c|}
\hline Futit $\neq 2$ & GEOT & & $3: 28$ & OJANBO & & & & & \\
\hline $\begin{array}{c}\text { AUEFIAGE } \\
\text { IS } \\
1677\end{array}$ & GEOT & & $3: 28$ & O JANBO & & & & & \\
\hline $\begin{array}{c}A L \\
9.970\end{array}$ & .0078 & $\begin{array}{c}E A \\
10 . i 1\end{array}$ & $\begin{array}{c}C A \\
.2398\end{array}$ & $\begin{array}{c}F E \\
10.16\end{array}$ & 26.3 & $\frac{L I}{.758}$ & $\begin{array}{c}M G \\
.1355\end{array}$ & $\begin{array}{l}\text { KA } \\
504\end{array}$ & $\begin{array}{c}F \\
.2877\end{array}$ \\
\hline $\begin{array}{c}S I \\
3190 \\
A G\end{array}$ & $\begin{array}{c}S E \\
10.17 \\
\text { AS }\end{array}$ & CII & $\mathrm{CO}$ & $C E^{+}$ & CU & Mis & MO & $N I$ & $F \cdot B$ \\
\hline $\begin{array}{c}.0284 \\
\text { 9E } \\
9.569\end{array}$ & $\begin{array}{c}1189 \\
\text { SE }\end{array}$ & $\begin{array}{c}.0037 \\
\text { SN } \\
10.04\end{array}$ & $\begin{array}{c}0 \\
\mathrm{TH} \\
.6596\end{array}$ & $\begin{array}{c}.0056 \\
11 \\
10.00\end{array}$ & $\begin{array}{c}.0121 \\
\text { IL } \\
.4519\end{array}$ & $\underbrace{.0022}_{0}$ & $\begin{array}{c}10.08 \\
2 N \\
.0 \pm 83\end{array}$ & $\begin{array}{c}10.19 \\
\frac{1}{4} \\
9.932\end{array}$ & $<$ \\
\hline
\end{tabular}

*O/ STI 4

EHGCGHAC

\begin{tabular}{|c|c|c|c|c|c|c|c|c|c|}
\hline $\begin{array}{r}\text { EULFN } \\
1679\end{array}$ & GEOT & & $3: 54$ & O JANGO & & & & & \\
\hline$\therefore 101.7$ & $\begin{array}{r}9.997 \\
.0149\end{array}$ & .0000 & .4824 & .0149 & 7.79 & .0021 & .2045 & 1278 & 9.871 \\
\hline $\begin{array}{l}.0070 \\
.0195\end{array}$ & $\begin{array}{l}10.48 \\
8.269\end{array}$ & $\begin{array}{l}0 \\
0\end{array}$ & & $\begin{array}{r}9.593 \\
.0080\end{array}$ & $\therefore 0021$ & $\begin{array}{l}.0012 \\
.0030\end{array}$ & $\begin{array}{r}.0765 \\
0\end{array}$ & $\begin{array}{l}.0195 \\
.0231\end{array}$ & .0084 \\
\hline
\end{tabular}

EUFN 2 GEOT $2: 55$ 3OJANGO

AVETAGE GEOT 8:55 30JAHJO

IS

$10>0$

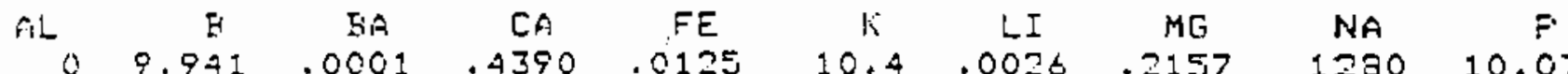

$\because \begin{array}{cccccccccc}0 & 9.941 & .0001 & .4390 & .0125 & 10.4 & .0026 & .2157 & 1230 & 10.07\end{array}$ 102. 0.0140

$A G \quad C I I \quad C O \quad C F F$ CL MN HO $\begin{array}{lllllllllllll}.0089 & 10.47 & .0011 & 0 & 9.617 & .0019 & .0002 & .0734 & .0033 & .0000\end{array}$ $\begin{array}{ccccccccc}S E & S E & S N & T H & T I & T L & U & Z N & Z \pi \\ .0088 & 0.234 & 0 & .0047 & .0087 & 0 & .0325 & 0 & .0224\end{array}$ 


\section{RESULTS}

\section{Matrix Interferences}

Sample matrix problems are not totally eliminated in ICP analyses. Solution viscosity and dissolved solids content are the most prevalent matrix problems. Ward, Sobel and Crawford (1975) reported interferences from sulfuric acid and dissolved solids. A 1 M sulfuric acid solution showed significant suppression of element concentrations over unacidified standards. Hydrochloric, perchloric and nitric acid exhibited only small influences at the 1 M level. This information is reproduced in Table A.4.

Uranium mill tailings solution from the sulfuric acid leach process should experience matrix interferences. The Highland Mill taitings solution had a 0.13 sulfuric acid concentration. It was assumed that the reported ICP results were suppressed because of the sulfuric acid, but the extent was not determined for all elements. The recomended procedure for future analysis of uranium mill tailings solutions is preparation of elemental standards more closely matching sampie acidity for all reported elements.

TABLE A.4. Effect of IM Acids on Analytical Signals of Elements at the $250 \mathrm{\mu g} / 1$ Level

\begin{tabular}{|c|c|c|c|c|}
\hline Elenent & $\mathrm{HCl}$ & ${\underline{\mathrm{HC}} 10_{4}}_{4}$ & $\mathrm{HNO}_{3}$ & $\underline{\mathrm{H}}_{2} \mathrm{SO}_{4}$ \\
\hline $\mathrm{Al}$ & $+5 \%$ & 0 & $-11 \%$ & $-30 \%$ \\
\hline $\mathrm{Ca}$ & (a) & (a) & $-14 \%$ & $-42 \%$ \\
\hline Cd & $+2 \%$ & $-4 \%$ & $-10 \%$ & $-29 \%$ \\
\hline Co & $+2 \%$ & $-4 \%$ & $-7 \%$ & $-26 \%$ \\
\hline $\mathrm{Cu}$ & $+1 \%$ & $-5 \%$ & $-7 \%$ & $-30 \%$ \\
\hline$M g$ & $+2 \%$ & $-5 \%$ & $-7 \%$ & $-23 \%$ \\
\hline $\mathrm{Na}$ & $-11 \%$ & (a) & $+3 \%$ & $-45 \%$ \\
\hline $\mathrm{Ni}$ & 0 & $-5 \%$ & $-8 \%$ & $-30 \%$ \\
\hline $\mathrm{Zn}$ & $+5 \%$ & $-3 \%$ & $-10 \%$ & $-30 \%$ \\
\hline
\end{tabular}

(a) No measurement due to acid impurities 
The other major matrix problem, dissolved solids content, causes unwanted radiation that enhances elemental vaiues. All unwanted radiation reaching the detector is treated as background. Corrections were made wherever possible or the detection limits were raised to account for the excess. Ward, Sobei and Crawford (1976) reported the effects of $1000 \mathrm{mg} / \mathrm{l}$ concentrations of $\mathrm{Al}, \mathrm{Ca}, \mathrm{Fe}$ and $\mathrm{Mg}$ on $\mathrm{Al}, \mathrm{As}, \mathrm{Cd}, \mathrm{Co}, \mathrm{Cr}, \mathrm{Cu}, \mathrm{Fe}, \mathrm{Mn}, \mathrm{Pb}$ and background. Iron produced the highest interferences of the four cations tested. Table A.5 shows the results.

These interferences were observed from the analysis of six synthetic uranium nill tailings solution samples. The synthetic solution was formulated to contain the major elements of the tailings solution except for the radionuclides. Positive signals for eienents not added to the synthetic solution appeared in the uncorrected data. The composition of the synthetic soiution and the analytical results are listed in Table A.6. One or more of the tabulated values for $\mathrm{As}, \mathrm{Cd}, \mathrm{Co}, \mathrm{Cr}, \mathrm{Cu}, \mathrm{Mn}, \mathrm{Pb}, \mathrm{Si}, \mathrm{Sr}, \mathrm{Th}$ and $\mathrm{Zn}$ were observed greater than the corresponding detection limit. The average of the

TABLE A.5. Matrix Interference from $1000 \mathrm{mg} / 1$ Concentrations of Al, $\mathrm{Ca}, \mathrm{Fe}$ and $\mathrm{Mg}$ with Other Elements (expressed in $\mu \mathrm{g} / \mathrm{l}$ )

\begin{tabular}{|c|c|c|c|c|c|}
\hline Element & Wavelength & Al & $\underline{\mathrm{Ca}}$ & $\mathrm{Fe}$ & $\mathrm{Mg}$ \\
\hline Al & 308 & (a) & 40 & 400 & 180 \\
\hline As & 197 & 4350 & 0 & 1350 & 300 \\
\hline $\mathrm{Cd}$ & 227 & 40 & 0 & 320 & 40 \\
\hline Co & 239 & 12 & 5 & 10000 & 20 \\
\hline $\mathrm{Cr}$ & 268 & 7 & 12 & 150 & 30 \\
\hline $\mathrm{Cu}$ & 325 & 30 & 15 & 125 & 65 \\
\hline $\mathrm{Fe}$ & 260 & 70 & 45 & (a) & 160 \\
\hline$M n$ & 258 & 20 & 4 & 90 & 20 \\
\hline $\mathrm{Pb}$ & 220 & 1900 & 0 & 810 & 150 \\
\hline BKg & 252 & 120 & 65 & 11300 & 280 \\
\hline
\end{tabular}

(a) Major element 
IABLE A.6. Analysis of UMT Synthetic Solution, in $\mathrm{mg} / \mathrm{l}$

\begin{tabular}{|c|c|c|}
\hline Element & $\begin{array}{l}\text { Amount Added } \\
\text { to Solution }\end{array}$ & $\begin{array}{l}\text { Amount Found } \\
\text { in Solution }\end{array}$ \\
\hline Al & 577 & $571(8)^{(a)}$ \\
\hline As & 3.5 & $6.6(31)$ \\
\hline $\mathrm{Ca}$ & 484 & $530(7)$ \\
\hline $\mathrm{Cd}$ & - & $1.6(74)$ \\
\hline $\mathrm{Cr}$ & - & $0.2(113)$ \\
\hline $\mathrm{Cu}$ & - & $2.3(193)$ \\
\hline $\mathrm{Fe}$ & 2215 & $2226(30)$ \\
\hline $\mathrm{Mg}$ & 650 & $656(5)$ \\
\hline Mn & - & $2.2(8)$ \\
\hline $\mathrm{Na}$ & 308 & $348(5)$ \\
\hline $\mathrm{Ni}$ & - & $0.4(58)$ \\
\hline $\mathrm{Se}$ & - & none reported \\
\hline si & - & $1.8(101)$ \\
\hline$S r$ & - & $0.3(29)$ \\
\hline Th & - & $0.7(57)$ \\
\hline $\mathrm{Zn}$ & - & $0.7(80)$ \\
\hline
\end{tabular}

(a) Coefficient of variation

values did fall below the detection limits for all except $\mathrm{Cd}, \mathrm{Cu}$ and $\mathrm{Mn}$. There were no apparent interferences for $\mathrm{Ag}, \mathrm{Mo}, \mathrm{Ni}, \mathrm{Se}, \mathrm{Sn}, \mathrm{J}$ and $\mathrm{Zr}$. In general, the detection limits derived from the geotherma i standards did account for the matrix interferences from dissolved solids at high concentrations.

\section{Problem Elements}

\section{Arsenic}

The reported arsenic value of $3.5 \mathrm{mg} / 1$ is very questionable. As a check, synthetic tailings solution without As added was subritted for ICP analysis. It was reported to have $6.8 \mathrm{mg} / 1$ As, which was similar to that reported for five samples with $3.5 \mathrm{mg} / 1$. To date, the spectral interferences have not been identified for arsenic. 


\section{Selenium}

It is suspected that the presence of sulfuric acid suppresses the Se signal. No selenium had been detected in the uranium mill tailings or synthetic solutions below a pH of 4.0. The gaseous hydride method (EPA 1979) gave a value of $0.6 \mathrm{mg} / 1$ for the mill tailings solution. Values greater than $1 \mathrm{mg} / 1$ were reported in neutralized samples from the attenuation studies. 'Since the neutralized solution had been separated from the tailings, neutralization could not have released selenium from the tailings. The actual concentration of selenium in mill tailings solution could not be determined accurately from ICP analysis.

Uranium

ICP is reported as a good method for detecting uranium, however, sulfuric acid suppression is again suspected. Samples supposediy containing uranium were analyzed but no uranium was detected. This observation was brought to the attention of the analyst, who then determined the $U$ concentration to be $100 \mathrm{mg} / 1$. Based on radiochemical results, the level of uranilum in the solution was caiculated to be approximately $40 \mathrm{mg} / 1$, which more ciosely reflects the concentration expected to remain from the mill processing. Here again, the actual concentration of uranium in mill tailings solution could not be accurately determined by ICP analysis.

\section{Permeability Cell Data}

Results from the ICP analysis for a series of leachate samples from cells $P 1, P 5$, and $P 8$ are shown in Tables A.7, A.8, and A.9, respectively. Also presented are anion data from ion chromatography analysis run on the same samples. These tables reflect the type of the chenical analysis performed on the leachate samples. Where the analysis was below detection limits for a particular element, it is so indicated. Adequate analysis was obtained for the macroions $\mathrm{Ca}, \mathrm{Mg}, \mathrm{Na}$ and a number of the metal ions, particularly, $\mathrm{Al}$, Fe, and $\mathrm{Mn}$. 


\section{CONCLUSIONS}

Within the limits specified, ICP is a good multi-element analysis method for uranium mill tailings solutions. There are some matrix interferences due to the complex nature and acidity of the solutions. Detection limits are higher than those for solutions with less complex matrices. Future use of standards acidified with sulfuric acid should reduce the uncertainty assocjated with some of the elenents in uranium mill tajiings solutions. 
TABLEA.7. ICP Analysis: Permeability Cell P1 - Clay Liner and Symthetic Tailings Solution

\begin{tabular}{|c|c|c|c|c|c|c|c|c|c|c|}
\hline \multirow[b]{2}{*}{ Pore Volume: } & \multicolumn{9}{|c|}{ Leachate Sanoles $(\mathrm{mg} / 1)$} & \multirow[b]{2}{*}{ Detection } \\
\hline & 1.26 & 1.68 & 2.12 & 2.54 & 2.95 & 3.30 & 4.47 & 5.15 & 5.99 & \\
\hline p뮤: & 7.72 & 7.90 & 7.75 & 7.68 & 7.80 & 5.67 & 4.02 & 4.30 & 3.82 & $\operatorname{Limit}(1)$ \\
\hline \multicolumn{11}{|l|}{ Elentant } \\
\hline Al & $\mathrm{DL}^{(1)}$ & OL & DL & $\mathrm{DL}$ & DL & $\mathrm{DL}$ & 28.3 & 140 & 186 & 0.1 \\
\hline As & $\mathrm{OL}$ & a & $\mathrm{DL}$ & $a$ & al. & $a$ & 0.6 & 4.4 & 3.6 & 0.1 \\
\hline co & 618 & 508 & 633 & 680 & 644 & 675 & 595 & 570 & 541 & 0.1 \\
\hline cd & 매. & ot & $\mathrm{OL}$ & LL & DL & 0.02 & 0.4 & 0.9 & 0.7 & 0.01 \\
\hline $\mathrm{Cr}$ & OL & ol & LL & DL & DL & in & 0.2. & 0.5. & 0.02 & 0.01 \\
\hline Cu & 0.02 & DL & d & DE & 0.4 & 0.06 & OL & 0.2 & 0.2 & 0.01 \\
\hline $\mathrm{Fe}$ & $\alpha$ & $D L$ & OL & $\mathrm{OL}$ & DL & 31.5 & 645 & 1312 & 1582 & 0.1 \\
\hline Li & DL & $\mathrm{DL}$ & DL & 0.2 & 0.2 & 0.3 & 0.3 & 0.4 & 0.5 & 0.05 \\
\hline mg & 340 & 362 & 382 & 478 & 650 & 744 & 981 & 1091 & 1063 & 0.05 \\
\hline$M_{n}$ & 0.2 & 0.7 & 1.4 & 2.6 & 4.2 & 5.2 & 7.0 & 8.0 & 7.9 & 0.01 \\
\hline to & OL & ب & OL & DL & $x$ & DL & OL & $D L$ & 01 & 0.1 \\
\hline No & 220 & 231 & 238 & 256 & 304 & 330 & 350 & 420 & 399 & 5.0 \\
\hline $\mathrm{Ni}$ & $O L$ & $\mathrm{DL}$ & Q1 & 0.44 & 1.2 & $i, 9$ & 3.8 & 5.3 & 4.9 & 0.08 \\
\hline$P$ & $\mathfrak{D}$ & $D L$ & $a$ & $\mathrm{DL}$ & $a$ & 1.2 & 9.5 & 12.0 & 12.9 & 0.5 \\
\hline$p_{b}$ & DL & $\mathrm{DL}$ & DL. & $a$ & OL & DL & 0.9 & 2,0 & $D L$ & 0.1 \\
\hline se & $\mathrm{DL}$ & DL & $x$ & $\mathrm{DL}$ & DL & JL & $i .5$ & 3.3 & OL. & 0.1 \\
\hline 51 & 7.2 & 5.8 & 1.2 & 7.8 & 6.8 & 8.3 & 27.8 & 44 & 45 & 0.1 \\
\hline$s r$ & 10.0 & 7.3 & 11.5 & 14.0 & 19.0 & 21,3 & 21.0 & 19.8 & 18.7 & 0.01 \\
\hline Th & OL & DL & ol & DL & $a 1$ & DL & 2.0 & 2.4 & 0.4 & 0.1 \\
\hline$u$ & DL & $d L$ & DL & $\mathrm{OL}$ & DL & $\alpha$ & 23.1 & 44 & $D L$ & 0.05 \\
\hline $2 n$ & 0.50 & 0.56 & $\mathrm{dL}$ & 0.46 & 3.0 & 2.1 & 7.1 & 9.1 & 7.2 & 0.05 \\
\hline \multicolumn{11}{|c|}{ By lon Chrometography } \\
\hline $\mathrm{Ci}$ & 121 & 98 & 97 & 83 & 88 & 94 & 100 & 123 & $9 ?$ & 0.05 \\
\hline $\mathrm{SO}_{4}$ & 2445 & 2340 & 2690 & 3444 & 3833 & 4714 & 7147 & 8304 & 7984 & 0.1 \\
\hline
\end{tabular}

(1) DL - Less Than Detection Liarit 
TABLE A.8. ICP Analysis: Permeability Cell P5 - Clay Liner and Tailings Solution

Leachate Samoles $(\mathrm{mg} / 1)$

Pore Voiume:

pH:

Element

A)

As

$\mathrm{Ca}$

cd

Cr

Cu

re

6i

$\mathrm{Mg}$

$M_{n}$

Mo

Na

$\mathrm{Ni}$

$p$

Po

Se

$5 i$

$s r$

Th

13

in

3y Ion Chromatography

C1

$\mathrm{SO}_{4}$

$O L^{(i)}=$ Less Than Detection Limit
5.54

4.80

8.20

8.00

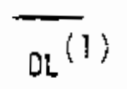

OL

D

592

$\mathrm{IL}$

OL

$\mathrm{OL}$

x

OL

192

ot

OL

152

0.2

OL

OL

OL

3.2

9.6

OL

0.4

0.5

132

292

3704

3.6

OL

0.56

0.64

15.2

26.4

0.8

DL

8.4

402

7864

$A-11$
6.24

4.20

.91

3.80

Detection (1)

Limit

45.2

161

0.1

0.7

0.8

0.1

461

421

0.1

0.4

0.8

0.נ

0.1

0.1

0.01

$0 . j$

0.2

0.01

538

350

0.1

1.0

1.1

0.05

1466

1677

0.05

54.4

39.6

0.01

DL

OL

0.1

296

285

5.0

0.7

9.5

0.08

2.8

2.8

0.5

$\mathrm{OL}$

0.4

0.1

OL

OL

0.1

23.2

28.8

0.1

22.4

22.0

0.01

2.0

3.2

0.1

DL

OL

0.05

14.4

19.6

0.05

303

306

0.05

9492

12192

0.1 
IABLE A.9. ICP Analys is: Permeability Cell P8 - Overburden and Tailings Solution

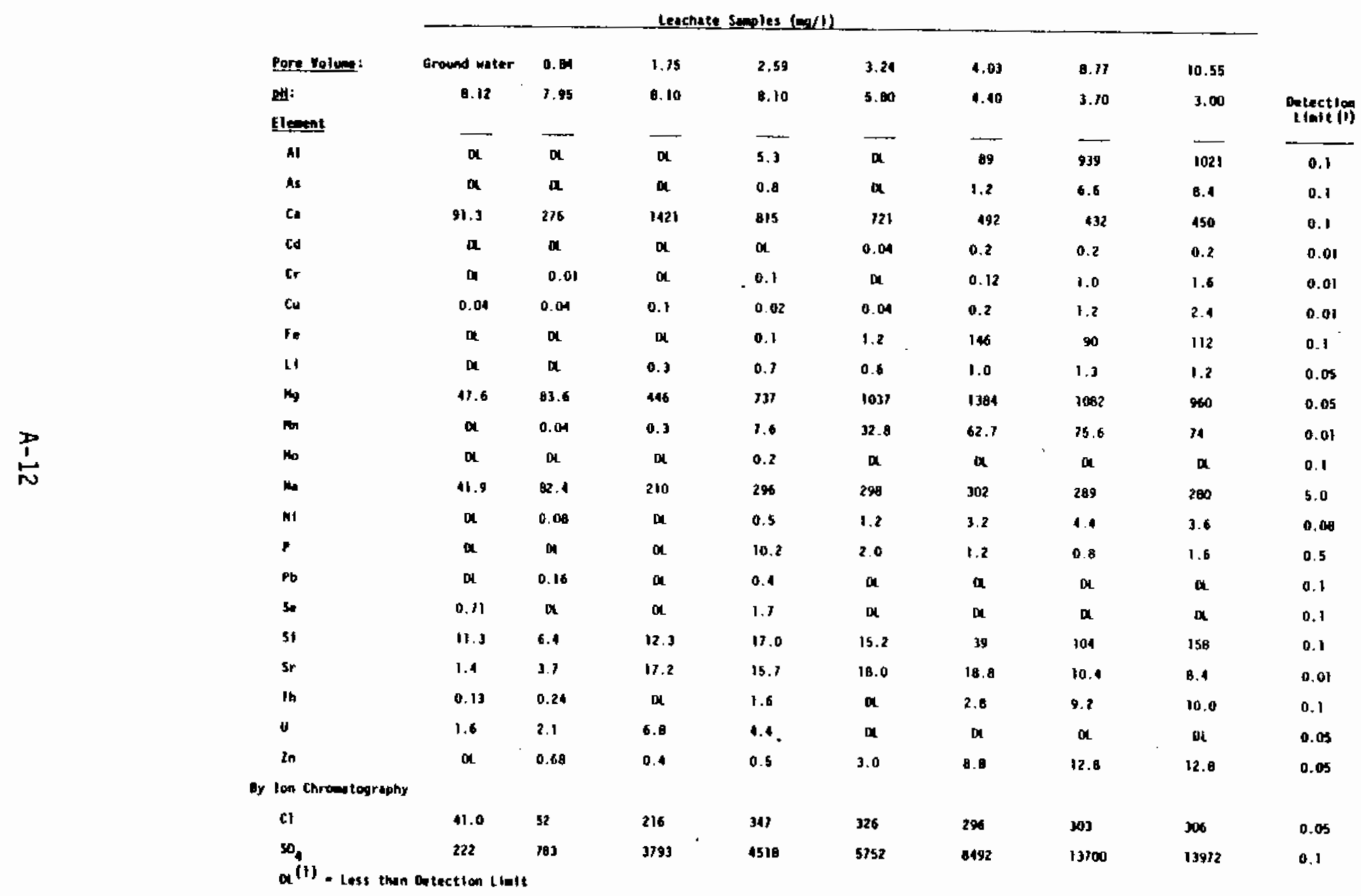




\section{APPENDIX B}

METHOD FOR DETERMINATION OF GAMMA EMITTING RADIONUCLIDES

IN URANIUM MILL TAILINGS AND TAILINGS SOLUTION 
APPENDIX B

METHOD FOR DETERMINATION OF GAMMA EMITTING RAOIONUCLIDES

IN URANIUM MILL TAILINGS AND TAILINGS SOLUTION

Uraniun ore contains $238 \mathrm{U}, 235 \mathrm{U}$, and 23 radioactive decay products. The time and effort involved in chemical separation of these nuclides make it impractical to use wet chemical techniques for their determination: As an alternative to chemical extraction, high resolution gama spectroscopy is used. This method yields information on the majority of isotopes in both the $238_{U}$ and $235_{U}$ decay series. Accurate measurements by this method depend on reproducible sample geometry, detector efficiency caibration, and the choice of good analytical peaks. This appendix provides an explanation of the parameters involved in spectroscopic analysis done for this project.

\section{SAMPLE PREPARATION}

A fundamental principle for any good analytical technique is reproducible sample preparation. All solid samples were pressed into thin discs. These discs were made to the same standard dimensions. Soil samples were ground and mixed with a cellulose binder material at a fixed ratio. The mixed sample was then piaced in a moid and pressed with $3.45 \times 10^{8} \mathrm{~N} / \mathrm{m}^{2}\left(50,000 \mathrm{lbs} / \mathrm{in}^{2}\right)$ pressure. Effluent solution samples were analyzed in the same fixed geometry disc form. A specific volume of solution was eyaporated to oryness, and the remaining solids were quantitativeiy transferred. A total weight of solids was taken, and the amount of sample needed to achieve the proper ratio was mixed with the binding material and pressed. The weight of solids used, divided by the weight of solids from the total volume evaporated, multiplied by the volume of effluent evaporated, gives the equivalent volume of solution

$\frac{\text { Solids Used }(g)}{\text { Solids in Tota! Volune (g) }} \times$ Total Volume $\left.(m]\right)=$ Volume Used $(m !)$ 
that was used in the disc. If the solids from the evaporated solution are less than that required to achieve the desired sample-to-binder ratio, a low activity sand is added to achieve the proper weight ratio. This procedure places both solid and liquid samples in a consistent geometry and allows for a single detector calibration on only one size and shape sample. To optimize detector performance, the sample is pressed to a thickness of less than $0.6 \mathrm{~cm}$ (0.25 in.), thereby minimizing sample seif-attenuation. The samples are aiso sized to a diameter equal to that of the active diameter detectors of the beryllium window. By placing all of the sample in a direct line of sight to the diode, detector efficiency is maximized. Once all of these physical parameters have been fixed, counting can begin.

\section{CALIBRATION}

In calibrating an intrinsic germanium diode, three major steps must be taken. The first step is to obtain a standard material that has multiple peaks and similar activity over the range of energies to be used for sample anaiysis. This material should be an interlaboratory comparison standard of verifiable quality. The second step is to put the standard material in the same geometry as described for the samples. The third step in accurate detector calibration is to determine a photopeak, or full energy, efficiency curve for the analytical energy range. The detector photopeak efficiency is the fraction of gamma rays of a particular energy emitted from a source that appears in the corresponding photopeak of the pulse-neight spectrum. The efficiency curve is determined by counting standards with known gamma ray activities in the same geometry that will be used for the experimentai sampies. Rate-dependent factors, such as dead-time and peak summing, shouid be considered and if necessary, corrections must be made for these effects. Insofar as the standard and experimental discs are of low activity, such ratedependent factors are not expected to be significant.

The reciprocal of the product of the efficiency, EY, and the absolute abundance, aY, for a gamma ray of energy, EY gives a scaler calied the "d/c* (disintegration/net peak count). This scajer wijl convert the net photopeak 
counts to the absolute disintegration rate provided that no interference occurs at that energy level from gamma rays of other radioisotopes. The absolute abundance for a particular gama ray is defined as the probability of emission per decay. Absolute abundance values are avallable from the literature and have been compiled by several authors.

\section{PEAK SELECTION}

Once the calibration of the detector has been completed, a list of all possible gamma energies with an abundance high enough to be analyzed is tabulated. Some energies will be used as analytical peaks, others to determine the overlap of peaks, and some will be unimportant because of the low activity of a certain nuclide in the sample. The relative peax heights of the various nuclides may change from sample to sample.

The two compilations used for comparison were the Table of Isotopes (TOI) (Lederer and Shirley, 1978) and "The Gamma-Ray Lines of Radionuclides, Ordered by Atomic and Mass Number," from the Journal of Radioanalytical Chemistry (JRC) (Ertmann and Soyka 1975). These two compilations were compared empiricaliy by developing efficiency curves for a detector using each set of absolute abundance values and the known $d / c$. The curve developed with the TOI values had smalier deviations from the calibration points than did the JRC values. As a result of this empirical comparison, the TOI values were used for all calculations.

A good illustration of this is to compare the spectra of uranium ore and uranium mill effluent solutions. The uranium ore sample is in its naturat equilibrium state, and its gamma spectrum consists of peaxs from daughter radionuclides that are in equilibrium with the parent uraniun isotopes. The mill effluent solution has been recycled several times. Uranium isotopes and their decay products are not in equilibrium in such a solution. Relative quantities of the nuclides in this sample are now dependent on each element's solubility as well as the decay constants. Some of these radionuclides are concentrated in the effluent solution, and their gamma peaks, which were not resolvable from background in the ore samples, are now significant. 
To determine whether or not a peak is of analytical quality, several situations need to be addressed:

1) Can the peak be resolved from other peaks in its energy region?

2) If the peaks in one energy region cannot be resolved, can the contribution of each nuclide be quantified by calculating the contributions of one or more nuclides from another known peak?

3) If the garma peaks from one particular nuclide are so close that they cannot be resolved, may the peaks still be used for analys is by summing the absolute abundances for each gama photon?

The best method for continually checking the results for different nuclide concentrations is to use multiple peak analysis for as many nuclides as is possible within each sample. This process involves the comparison of the activity value of a single nuclide calculated for as many of its gama energies as possible. Inconsistent results could go undetected if these crosschecking methods are not employed.

\section{EXAMPLE ANALYSIS}

To illustrate the applications of this method, here is the step by step procedure used for the analysis of ${ }^{227}$ AC in tailings solution. The reason for choosing ${ }^{227} \mathrm{AC}$ is that its concentration can be confirmed by the many gamma energies of its short-lived daughters. The verifications of ${ }^{227} \mathrm{AC}$ also incorporate many of the useful points in this method.

${ }^{227}$ Ac enits no detectable gama rays of significance, but it has a halflife that is long (22 years) when compared to its daughters. The effluent solution tested had been separated from the tailings solids for several months to insure that the nuclides in the ${ }^{235} \mathrm{U}$ decay chain, which occur after $227 \mathrm{AC}$, were in equilibrium with the ${ }^{227}$ Ac parent. This allows the use of any photo peaks enitted from the five gamma-enitting daughters to be used for analysis or confirmation.

The first step is to tabulate a iist of all of the photo-peak energies that could possibly be used for calculation of ${ }^{227}$ AC activity. Table B.I contains a list of the isotopes, absolute abundances, counting efficiencies, 
TABLE B.1. Analysis Information for ${ }^{227}$ AC Measurement

ISOTOPE Peak Energy (kev) Efficiency Absolute Abundance Channel of Peak

$227_{\mathrm{Th}}$

227 Th $49.9,50.1$

0.14

0.0766

250

${ }^{227} \mathrm{Th}$

236.0

0.025

0.112

1180

$223 \mathrm{Ra}$

256.0

0.21

0.0627

1280

$219_{\mathrm{Rn}}$

269.6

0.19

0.140

1348

${ }^{223} \mathrm{Ra}$

271.0

0.10

0.10

1355

${ }^{223} \mathrm{Ra}$

324.0

0.0135

0.0412

1620

338.6

0.0125

0.0296

1693

$211_{8 i}$

351.1

0.0120

0.127

1755

TABLE B.2. Radionuclide Concentrations from Energy Spectrum Analysis

\begin{tabular}{|c|c|c|c|c|c|}
\hline Isotope & Net Counts & Net Counts/min & $d / c$ & $d / m$ & $\mathrm{~d} / \mathrm{m} / \mathrm{T}(\mathrm{a})$ \\
\hline${ }^{227} \mathrm{Th}$ & 8,043 & 20.52 & 93 & 1,908 & 9,976 \\
\hline${ }^{227} \mathrm{Th}$ & 2,023 & 5.16 & 357 & 1,842 & 9,630 \\
\hline${ }^{227} \mathrm{Th}$ & 1,041 & 2.66 & 759 & 2,019 & 10,554 \\
\hline${ }^{223} 3_{\mathrm{Ra}}$ & 1,996 & 5.09 & 276 & 1,913 & 10,004 \\
\hline${ }^{21} 9_{R n}$ & 1,531 & 3.91 & 526 & 2,057 & 10,751 \\
\hline $223_{\mathrm{Ra}}$ & 331 & 0.844 & 1,798 & 1,517 & $7 ; 933^{(b)}$ \\
\hline${ }^{223} \mathrm{Ra}$ & 235 & 0.5995 & 2,703 & 1,620 & $8,468^{(b)}$ \\
\hline $211_{B i}$ & 1,182 & 3.02 & 656 & 1,981 & 10,356 \\
\hline
\end{tabular}

(a) $d / m / 1$ - disintegrations per minute per liter

(b) These peaks were not used for confinmation because of the low count rate.

channels near peak maximum, and garma photon peak energies for the analys is of ${ }^{227} A C$. The counting efficiency of the detector is taken from the efficiency curve at each respective energy (Figure B.1). For each peak of interest, a calculation of net counts must be made. In Figure B.2 this has been done for the 49.9 and 50.1 kev doublet peak of ${ }^{227}$ Th. The net counts are calculated by subtracting background counts from gross counts at each channel in the 


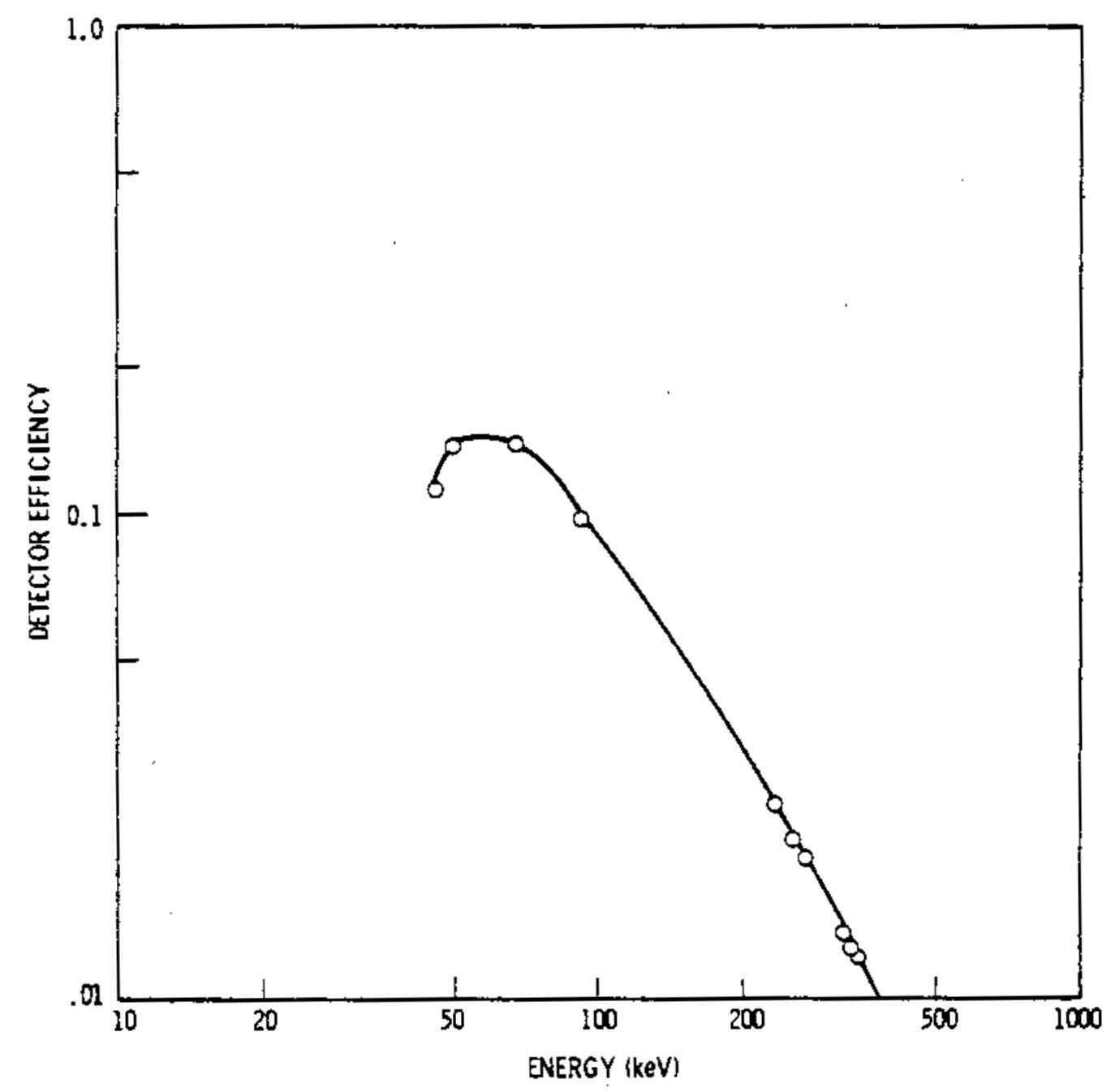

GIGURE 8.1. Detector Efficiency Curve for Intrinsic Germanium Diode

peak. The net count is then divided by the counting time in minutes. The result of this division is the net count rate for a particular gama photo peak. The net count rate is multiplied by the ' $d / c$ ' for that photo peak.

Caiculation for ${ }^{227}$ Th $49.9,50.1$ kev Doublet:

Gross Counts $\quad 10,163 \quad 8,043$ net $\mathrm{cts} \div 392 \mathrm{~min}=20.52$ net cts $/ \mathrm{min}$

Background $\quad \underline{2,120} 20.52 \mathrm{net} \mathrm{cts} / \mathrm{min} \times 93 \mathrm{disintegration/net}$ cts

Net Counts $\quad 8,043=1,908$ disintegration $/$ min 


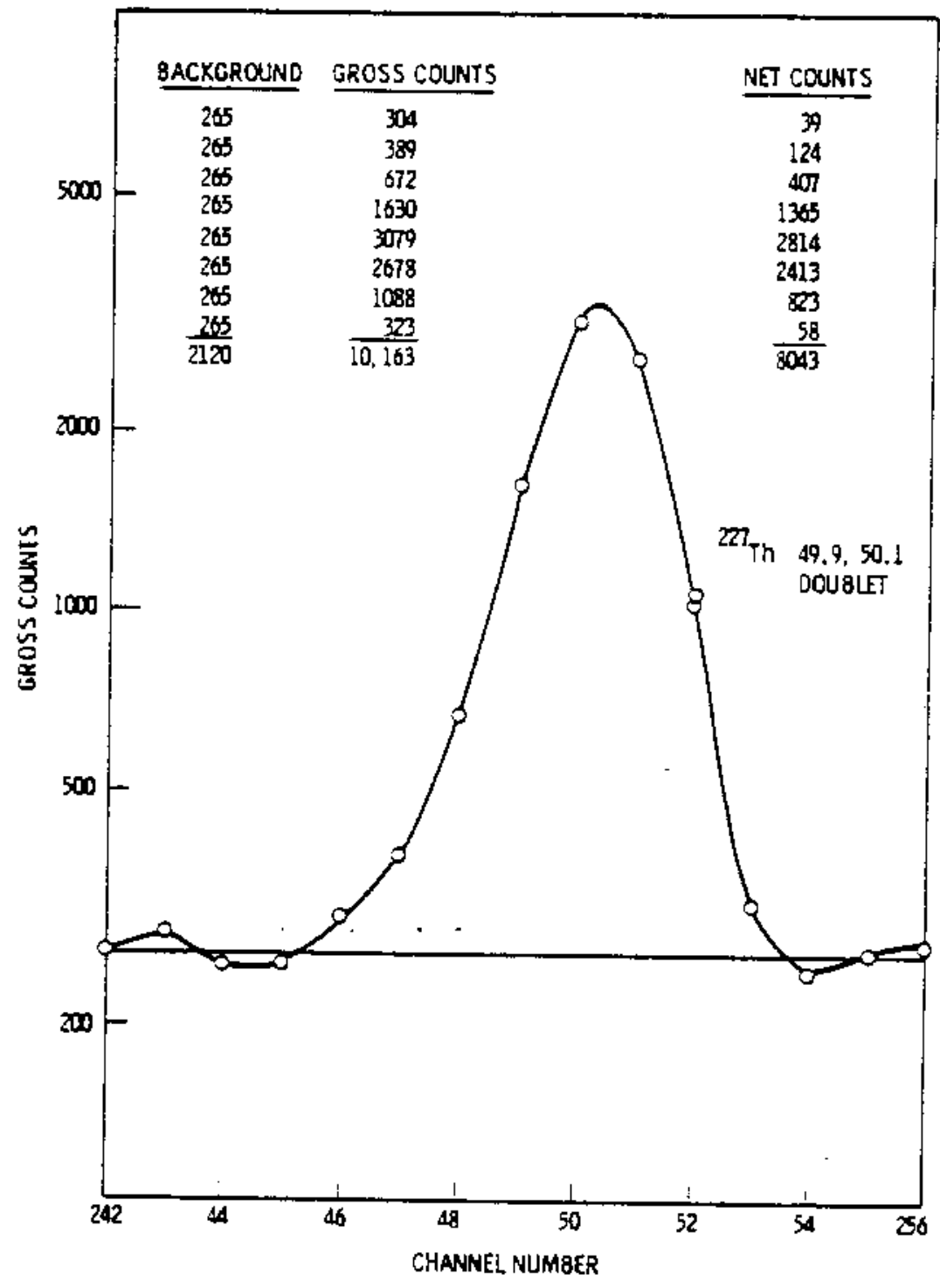

FIGURE B.2. Energy Sgectrum for 227Th Double Peak for Intrinsic Germanium Diode (227Th doublet occurs at 49.9 and $50.1 \mathrm{Kev}$, ) 
The disintegration rate that has been calculated is for a weight of salts for an equivalent volume. This disintegration rate $(d / m)$ is then divided by the equivalent volume to give disintegration rate in disintegrations/min/iter: $1,908 \mathrm{~d} / \mathrm{m}$ in 1,9131 counted $=9,974 \mathrm{~d} / \mathrm{m} / 1{ }^{227} \mathrm{Th}$.

These same calculations were done for all of the other peaks listed in Tabie B.1. Table B.2 shows the activity of the various ${ }^{227}$ AC daughters at all other tabulated energies. This method was used for all gama spectroscopy measurements taken for this project. 
No. of Copies

OFFSITE

A. A. Churm

DOE Patent Office

9800 S. Cass Avenue

Argonne, IL 60439

180 U.S. Nuclear Regulatory Commission

Oivision of Tectnical Information

and Document Control

7920 Norfolk Avenue

Bethesda, MD 20014

10 Laura Santos

Nuclear Regulatory Comission

office of Nuclear Research

Mail Stop 1130-SS

Washington, OC 20555

2

DOE Technical Intormation Center

\section{ONSITE}

50

Pacjfic Northwest Laboratory

G. W. Gee (43)

Publishing Coordination (2)

Technical Information (5) 


NRC FORM 335 U.S. NUCLEAR MEOULATORY COMMISSION
B.77)
BIBLIOGRAPHIC DATA SHEET

4. TITLE ANO SUETITLE HoO Voume Na, if Doradnan'

Interaction of Uranium MiTl Tailings Leachate with Soils and Clay Liners

Subtitle: Laboratory Analysis/Prooress Report

7. AUTHOR(S)

G. W. Gee and others

9. PEAFOAMING ORGANIZATION NAME AND MAILING ADOAESS (InClud Zio COdM/

Battelle - Pacific Northwest Laboratories

P. 0 . Box 999

Richland, Washington 99352

12. SPONSOAING ORGANIZATION NAME ANO MAILING ADORESS (Inglud Zip Codo"

U.S. Nuclear Regulatory Commission

Office of Muclear Regulatory Research

Wastington, OC 20555
3. REPOAT NUMBE R LAWGH OY DOC

NUREG/CR-1494

PNL -3381

2. (Leme olenk)

3. AECIPIENT'S ACCESSION NO

5. DATE REPOAT COMPLETED

\begin{tabular}{l|l|}
\hline MONTH MLY & YEAM \\
\hline DATE AEPORT ISSUED & 1980 \\
\hline MONTH JUNE & \\
\hline
\end{tabular}

6. (Lewe demk)

8. Leve benk!

10. PROJECT!TASKIWORK UNIT NO.

11. CONTRACT NO

FIN No. 82292

13. TYPE OF REPORT

Progress Repôrt/ Technical

Laboratory tests were conducted to evaluate leachate from uranium site in centra? wyoning. Laboratory tests included:

1. Physical and chemical characterization of geologic materials from the Morton Ranch. The materials characterized were typical of those found in the area of the proposed tailings pits.

2. Physical and chemical characterization of acid leach tailings and tajlings solution from the nearby Exxon Highland Mill.

3. Leaching tests with selected tailings materials and leach solutions.

4. Adsorption studies measuring the sorption characteristics of heavy metals and radionuclides on the Morton Ranch geologic materials under low and eeutral pH conditions.

5. Clay Tiner stability tests. These tests were designed to evaluate the mechanisms of clay liner alteration under acid attack and assess any long term changes in permeability of the clay liner materials.

permeability, adsorption studies

clay liner stability

17b. IDENTIFIEASIOPEN-ENOED TERMS

18. AVAILABILITY STATEMENT

Un? imited

\begin{tabular}{|c|c|}
\hline $\begin{array}{l}\text { 19. SE CUR!TY CLASS IThis reoont } \\
\text { Unclass if jed }\end{array}$ & 21. NO. OF PACES \\
\hline 20. SECURITY CLASS IThis Paghl & $\begin{array}{l}\text { 22. PRICE } \\
\mathrm{S}\end{array}$ \\
\hline
\end{tabular}


HANFORD TECHNICAL LIBRARY

\ل||

33679000552630

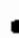

